Historic, archived document

Do not assume content reflects current scientific knowledge, policies, or practices. 


\section{MY FOUR}

1. I Warpant Your Remittence to Reach Me,

If sent by either post oflice or express money order, bank draft or registered letter. No other method is absolutely safe, though many do send bille, postage and coin in letters unregistered. Extra seods will be sent to the amount of the cost of the order, draft or registered letter when money is sent by either of these methods

Use my Coin Carrier, and send coins for small orders, and do not send stamps if it can be avoided I have no larger proportion of complaints from miscarriage of letters containing coin than those containing stamps, and either is a sufficiently safe way of remitting small smounte

If you sand postage stamps. send only the one and two cent size and do not tear them apart nor etick them to the paper.

2. I Warrant My Seeds to Reach You,

Provided you notify me of their non-arrival within two weeks of the time of sending your order and enclose a duplicate of it. YOU SHOULD RECEIVE YOUR SEEDS WITHIN ONE OR TWO DAYS of the actual time it takes the mail to come and go between the two points, as I INVARLABLY FILL in the afternoon ALL ORDERS RECEIVED that morning, and those received in the afternoon not later than the next morning. Promptness is my motte. Try me.

\section{GREETING.}

DEAR PATRON:-I present you herewith my latest and best list of choice seeds and hespeak for it your kindly interest. MISS EMMA V. WHITE.

\section{DUPLICATE CATALOGUES.}

Should you receive a duplicate of this Catalogue, please hand it to some person who cultivates flowers.

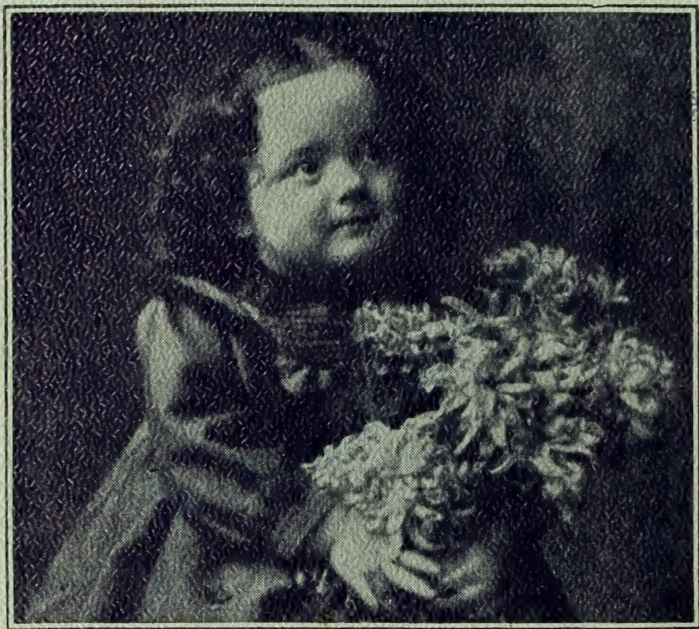

"My mamma plants Miss White's seeds.'

\section{WARRANTS.}

\section{I Warrant My Seeds to be} Good.

No honest seedsman can promise that seeds will grow, as il all depends on the conditions. I KNow BY ACTUAL TESTING that my seeds are good, but if ANY FALED TO GROW for you last year, and YOU ARE ENTIRELY SATIBFIED that the fallure is due to lack of vitality in seeds, and NOT TO SOME OTHER CAUsk, you may feel at liberty in placing your order with me this year to include such varieties. I desire to satisfy MY CURTOMERs, and some may believe that seeds which thoy received were poor. In MAKING APPLICATION FOR SEED to be replaced, please refer to the date of last spring's order in which it was included. It is my purpose to renew this offer from year to year.

Seeds of Greenhouse Plants, which generally require special care. are excepted from this offer to replace.

\section{I Warrant My Packete of Satisfactory Size.}

Some seed houses state the number of seeds in each packet, but I have abandoned the practice on account of the tendency to increase quantity at the expense of quality. But I guarantes satisfaction to my patrons in this particular also, and while my packets will average as large as from any seed house, price considered, you are at liberty to return unopened (at once) any packet you are dissatisfied with, and the cost (less postsge) will be promptly refunded.

TESEND FOR TERMS TO AOENTS TO SELL MY CHOICE SEEDS. EY 


\section{PREMIUMS $\odot$}

TAKE NOTICE! These premiums of plants or seeds are offered for orders of seeds in packets, at full prices only. No premiums allowed on collections, or on seeds by the ounce or quantity. Premiums must be asked for at the time the order is sent. Orders sent at different times cannot be taken together to entitle one to a premium. All premiums will be sent postpaid.

\section{PREMIUMS OF PLANTS}

\section{For a 50=Cent Order.}

Select one of the following choice plants:

1. Tea Rose, Champion of the World [pink]

2. "6 "6 Clothilde Soupert [blush].

3. " " Etoile de Lyon [yellow].

4. " "Kaiserin Augusta Victoria [white].

5. " "Meteor [dark red].

6. " "Marion Dingee [deep crimson].

7. Hardy Hydrangea, Paniculata Grandiflora.

8. Rudbeckia, Golden Glow.

\section{For a 75-Cent Order.}

Select one of the following, or one from the 50-cent offer if preferred:

1. Hardy Hvbrid Perpetual Rose, Prince Camille de Rohan [nearly black].

2. Hardy Hybrid Perpetual Rose, Alfred Colomb [red].

3. " "y "

4. " " " "Madam Plantier [white].

5, Crimson Rambler climbing rose.

6. Pink Ramber climbing rose.

7. White Rambler climbing rose.

8. Yellow Rambler climbing rose.

9. Baltimore Bell [pale blush] climbing Rose.

10. Mary Washington [white] climbing Rose.

11. Queen of the Prairies [pink] climbing Rose.

12."Russell's Cottage-[red] climbing Rose.

$\$ 250$ CASH PRIZES

GIVEN AWAY!!

Ist prize, \$50.00

2d prize, 30.00$\} * * *$ FREE TO ALL. ***

3d prize, 20.00

4th prize, 15.00

5th prize, 10.00

25 prizes of

$\$ 5.00$ each.

With each order of fifty cents, or upwards, for my Seeds I will send freo (when requested in the order), a mixed $\{$ packet (500 seeds), containing 30 varieties of choice Flower Seeds, selected from the varieties described in this Catalog. The above prizes will be given to those growing and naming correctly the largest number of varieties from this packet.

A certificate admitting you to this contest and giving full directions will be sent with each packet.

This packet will be given in addition to my regular plant or seed premiums offered on this page.

\section{PREMIUMS OF SEEDS.}

If premiums of flower seeds are preferred instead of plants; on any order for 50 cents, or upwards, select 30 per cent additional of fiower seeds in packets; that is, for a 50-cent order, select 15 cents worth of flower seeds additional, for a 75-cent order, 22 cents additional; for a $\$ 1.00$ order, 30 cents additional. Do not select as premiums vegetable seeds, flower seeds by the ounce or in quantity, or in collections.

Premiums of Plants.-Continued.

For a $\$ 1.00$ Order.

Select one of the following, or two from the 50 cent offer:

1. Clematis, Henryii [white].

2. Clematis, Jackmanni [blue].

3. Clematis, Mad. Edward Andre [red].

4. Japan Cedar, a substitute for Auraca-

ria Excelsa, or Norfolk Pine.

6. Yucca Filamentosa, hardy shrub.

(See page 55.)

Clematis and other shrubs are sent dormant and cannot be mailed later than about the middle of April. Roses and Japan Cedar can be sent up to June 1st.

\section{NOTE MY SPECIALTIES.}

Sweet Poas, - Pages 3-7 Asters, - - - Pages 7-10

Pansies, - - Pages 40-42

EX EXTRA PREMIUM! Other House Plants," will be sent in addition to other premiums offered. 
CHILDREN'S COLLECTION.

6

Plzts.

FOR

10 Cts.

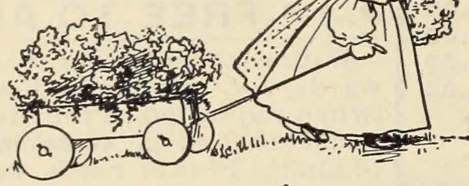

Over 50 Different Kinds and colors.

BOYS AND GIRLS, Here is a collection of choice sized packets, all easily grown and especially selected to please you. See regular list for description.

1. Ornamental cotton. Ornamental in foliage, flower and boll. Easily raised in all parts of our country. Price, 5 cts.

2. New Yellow Hyacinth Bean. A fine climbing plant, with light green foliage, yellow flowers and curious seed pods. Great climber. Price, 5 cts.

3. "Hit or Miss." A mixed package of many sorts. Price, 3 cts.

4. Pansy. Pansy viola tricolor, many sorts mixed. Price, 3 cts.

5. Double Portulaca. Beautiful assortment of colors, as double as roses. Price, 4 cts.

6. Sweet Peas. Grandiflora, mixed. Large flowered varieties in beautiful selection. Price, 3 cts.

\section{A11, 23 cents, for 10 cents.}

\section{HERB GARDEN.}

Ten popular aromatic plants, valuable for medicine, garnishing, flavoring. or imparting pleasant odors. 1. Caraway. 2. Coriander. 3. Dill. 4. Lavender. 5, Rosemary. 6. Sage. 7. Sweet Fennel. 8. Sweet Marjoram. 9. Summer Savory. 10. Thyme. Large packet, 10 varietie mixed, $10 \mathrm{cts}$,
MIXED PERENNIAL SEEDS.

Why not have a bed of hardy perennials? It requires but little care when once established. A slight dressing of manure in the spring, an occasional weeding, a light protection of leaves or straw in the fall, with a thinning out or division of plants once in a while to prevent over-crowding, and it will afford a succession of bloom from the earliest springtime throughout the season. To assist my patrons in securing such a bed, I offer a mixed packet of perennial seed, containing the following perennials and biennials contained in this catalogue, viz.:

No. 1. - 1. Achillea Ptarmica. 2. Agrostemma Coronaria. 3. Anchusa Capensis, 4. Arabis Alpina. 5. Candytuft, Iberis Gibraltrica, 6. Canterbury Bell. 7. Chrysanthemum Maximum. 8. Columbine. 9. Coreopsis Lanceolata. 10. Daisy. 11. Dianthus Plumosus. 12. Digitalis Monstrosus. 13. Feverfew, Golden Feather. 14. Feverfew, Matricaria. 15. Forget-MeNot. 16. Gaillardia Grandiflora. 17. Garden Heliotrope. 18. Gladiolus. 19. Gypsophila Paniculata. 20. Heuchera Sanguinea. 21. Hibiscus. 22. Hollyhock. 23. Larkspur. 24. Lavender. 25. Lychnis. 26. Lily of the Valley.

No. 2. - To give my patrons a still greater variety, I offer a second mixture, including a number not described in my regular list:

1. Achillea Milleflorum (rose). 2. Aconitum Napellus (blue). 3. Alyssum Saxatile (yellow). 4. Anemone Coronaria (mixed). 5. Baptisia Australis (blue). 6. Campanula Carpathica (blue). 7. Dictamnus Albus (white). 8. Gentiana Aucalis (blue and yellow) 9. Geum Astroisanguineum (scarlet). 10. Hypericum Moserianum (yellow). 11. Lobellia Cardinalis (Cardinal flower). 12. Lunaria Biennis (Honesty). 13. Marguerite Carnation. 14. Pentstemon (mixed). 15. Physalis Franchetti. 16. Pink (Chinensis). 17. Platycodon. 18. Poppy (Iceland). 19. Poppy (Oriental). 20. Salvia Argentea. 21. Senecio Elegans. 22. Snapdragon. 23. Stocks, 24. Sweet Rocket. 25. Sweet William. 26. Scabiosa Caucasica.

Either of the above Mixtures, Large Packet, 10 Cents.

\section{MIXED HARDY CLIMBERS.}

African Horned Cuumbers Balloon Vine Brazilian Morning Glory, Bryonopsis Laciniosa, Canary Bird Flower, Centrosema Grandiflora, Cypress, Gourd, Hyacinth Bean, Japanese Hop, Japanese Morning Glory, Kenilworth Ivy, Lace Vine, Maurandia, Mina Lobata, Momordica Balsamina, Moonflower Grandiflora Scarlet Runner, Sweet Pea Everlasting.

\section{Large Packet, Mixed, 19 Varieties, 10 cents.}

\section{OLD-FASHIONED GARDEN.}

"As for marigolds, poppies, hollyhocks, and various sunflowers, we shall never have a garden without them, both for their own sake and the sake of the old-fashioned folk who used to love them."-Henry Ward Beecher.

1. Aster. 2. Bachelor's Button. 3. Balsam. 4. Candytuft. 5. Coreopsis. 6. Dahlia. 7. Double Hollyhock. 8. Larkspur. 9. Marigold. 10. Mignonette. 11. Poppy. 12. Double Sunflower. 13. Wallflower.

13 Packets of these Old $z$ Fashioned Favorites for 25 cents. 


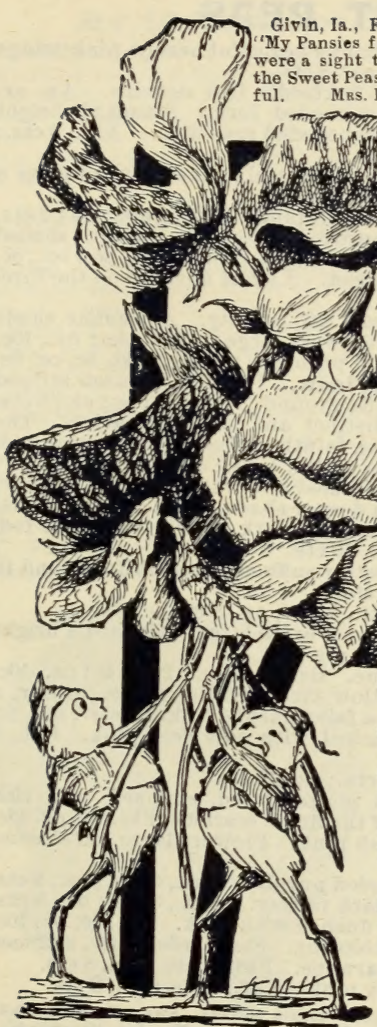

3 cts.; oz.. 8 cts.

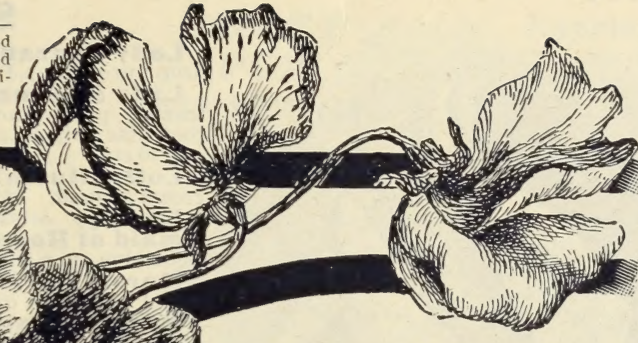
and rich. Pkt., 4 cts.; oz., 10 ets.

Blanche Ferry, extra early. The popular pink and white. Pkt., 3 cts.; oz. 8 cts.

Burpee's New Countess: Standard and wings, a most beautiful, clear, light lavender. Pkt. 3c, oz. 8c.

Captain of the Blues. Stand-

\section{SWEET PEAS.}

\section{Best Fifty Varieties.}

I make a specialty of this popu lar flower, and offer a list of Standard Varieties, and Proved Novelties that cannot be surpassed. It contains the very best in cultivation today, with duplicates practi cally discarded, except as there is a demand for certain similar varieties, and is a "Survival of the Fittest" of all the best sorts introduced up to the present time.

America. The brightest blood-red striped. Pkt., 3 cts.; oz., 8 cts. Apple=Blossom. Bright rosy pink and blush. Pkt., 3c.; oz., 8c. Aurora. Flaked orange salmon on a silver white ground. Pkt. 3c.; oz. 8c Black Knight. New rich wine-brown or deep clare. Flowers very dark

Blanche Burpee. Eckford's large pure white. Pkt., 3 cts.; oz., 8 cts. Captivation. Light magenta, beautifully veined. Pkt., 3 cts.; oz., 8 cts.

Chancellor. Soft rose pink, heavily veined and shaded at the base of standards a rich salmon or ange. Pkt., 3 cts. ; oz., 8 cts.

Colonist. Flowers very large; standard glowing, rosy pink, wings showing deeper rose shadings. Pkt., 3 cts.; oz., 8 cts.

Countess of Cadogan. One of Eckford's 1900 novelties. Has the prettiest porcelain blue wings; standards purplish blue. It comes close to a

blue. Pkt., 4 cts. ; oz., 10 cts.

Dorothy Tennant. Deep rosy-mauve; beauiful. Pkt., 3 cts.; oz., 8 cts.

Duke of Westminster. One of Eckford's 1900 Charlton City, Mass., April, 1900.-“"Your novelties. Deep rose maroon, overlaid with bright seeds are fine. All came up." Mrs.L.M.Copen violet; perfectly distinct. Pkt., 4 cts, ; oz., 10 cts.
Earliest of A11. A pink and white of the Blanche Ferry type, blooming from ten days to two weeks earlier than Extra Early Blanche Ferry. The plants are only about two feet high and can be grown without support. Very desirable for commercial purposes on account of its earliness and long season of bloom. Pkt., 4c.; oz., 10c.

Emily Eckford. Flowers large and fine. Reddish mauve and blue. Pkt., 3 cts.; oz., 8 cts.

Emily Henderson. One of the standard white varieties. Pkt., 3 cts.; oz. 8 cts.

Gorgeous. One of the largest and richest orange pink shades. Deep orange salmon, beautifully veined. Pkt., 4 cts.; oz., $10 \mathrm{cts}$.

Gray Friar. Beautiful watered purple on white ground. Pkt., 3 cts.; oz., 8 cts.

Hon. F. Bouverie. Eckford's 1900 novelty. A charming flower of grand shape and substance; color a beautiful coral pink. Pkt., $4 \mathrm{c}$.; oz., 10c.

Lady Grisel Hamilton. Eckford's 1900 novelty. One of the handsomest pale-lavenders; very large and free flowering. Pkt., $4 \mathrm{c}, ; \mathrm{oz} ., 10 \mathrm{c}$.

Lady Mary Currie. New. Orenge pink, suffused with rosy lilac and heavily veined. Very beautiful. Pkt., 3 cts.; oz, 8 cts.

Lady Nina Balfour. New, large, beautiful hooded of pale lavender or lilac. Pkt. $4 \mathrm{c}, \mathrm{oz} .10 \mathrm{c}$. 


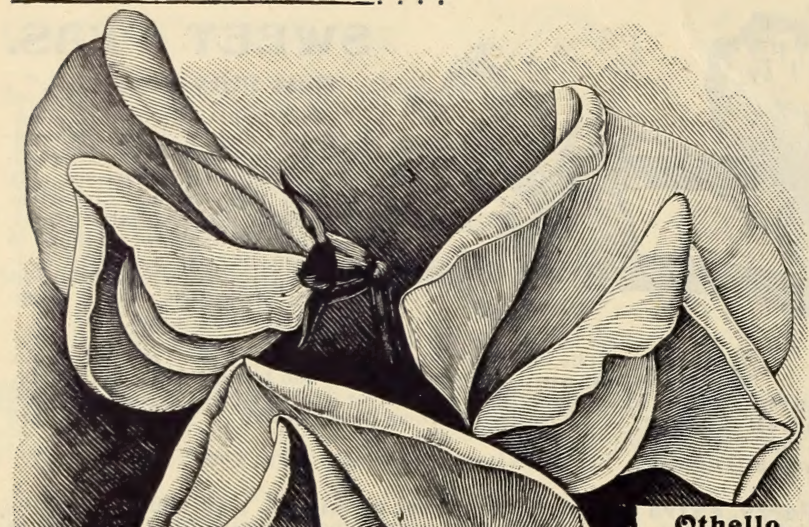

\section{SWEET PEAS.}

Lady Penzance. Standard a beautiful orange-pink; wings deep pure pink. Pkt., 3 cts.; oz., 8 cts.

Lady Skelmersdale. Eckford's 1900 novelty. An extremely pretty variety of the hooded form. Standards bright rosy lilac; wings, white, slightly shaded rosy lilac. Pkt., 4 cts.; oz.. $10 \mathrm{cts}$.

Lottie Hutchins. New. Delicately flaked with pink on a cream ground. Pkt., 3 cts.; oz., 8 cts.

Lovely. A beautiful soft shell pink. Pkt., 3 cts,; oz., 8 cts. Maid of Honor. An improved Butterfly. Flowers shaded light blue, on a white ground, and edged violet. Pkt., 3c,; oz.. 8c. Mars. Eckford's New Scarlet. A great advance on the Firefly. Pkt., 3 cts.; oz., 8 cts.

Mrs. Dugdale. Eckford's 1900 novelty. A peculiar shade of pink, with wings of buff pink, very large. Pkt., 4c.; oz., 10c.

Mrs. Eckford. Beautiful primrose yellow. Pkt. 3c, oz. 8c. Mrs. Joseph Chamberlain. The handsomest striped Sweet Pea, lovely pink on white ground. Pkt., 3 cts.; oz., 8 cts.

Navy'Blue. New, A distinct and striking variety. The color is a deep lavender purple, faintly suffused with a wine-red, giving the effect of a true blue. Pkt., 4 cts.; oz., 10 cts.

Oriental. Large, finely formed flowers of a bright orangesalmon heavily veined with \& deeper shade. Pkt., 3cts; oz. 8cts.

Othello. Eckford's 1900 novelty. A beautiful dark brown, chocolate red, a color not before obtained. Pkt., 4 cts.; oz., 10 cts.

Pink Friar. A soft carmine rose, delicately suffused on a white ground in finely watered markings. Pkt., 3 cts.; oz., 8 cts.

Prima Donna. Light blush-pink. Pkt., 3 cts.; oz., 8 cts.

Prince Edward of York. New. Flowers extra large; standard a bright scarlet, wings a deep rose. Pkt., 4 cts.; oz., 10 cts.

Prince of Wales. New, very handsome. Bright rose. Pkt., 4c; oz., 10c. Queen Victoria. The nearest to a yellow except Stella Morse. Color, a soft primrose yellow, slightly overlaid with a faint purple. Pkt., 3 cts.; oz. 8c. Ramona. Creamy white, daintily splashed with soft flesh pink. Prt., 3 cts.; oz., 8 cts.

Royal Rose. Deep rosy pink. Pkt. 3 cts.; oz., 10 cts.

Salopian. Deep crimson, tinged with mulberry-red. suffused with rich

\section{Sadie Burpee,}

\section{Bckford's}

\section{New White.}

The Sadie Burpee is the newest and best white sweet pea in quality of flower, and of a much higher germinating power than any other white variety. It is of the popular hooded form and the prettiest shaped flower yet produced. Pkt., 4 cts.: oz., 10 cts.

\section{SPLENDID ORFER.}

One packet each of my fifty named varieties, $\mathbf{8 1 . 0 0}$. Any ten packets, 25 cts. orange scarlet, giving a scarlet effect. One of the finest scarlets, Pkt., 3c, oz. 18c. Sensation. White suffused with a blush pink. Flowers large, often coming four on a stem. Pkt., 3 cts.; oz., 8 cts.

Shahazada, New. Dark maroon, shaded purple. Pkt., 3 cts.; oz., 8 cts. Stanley, Rich dark maroon. A fine dark variety. Pkt., 3 cts.; oz., 8 cts. Stella Morse, New. Rich primrose, flushed with pink. Pkt. 4c, oz. 10c. Triumph, Flowers of grand size and coloring. Standards white, suffused with salmon pink ; wings veined with rosy carmine. Pkt., 3 cts.; oz., 8 cts.

Venus, Lovely salmon buff, shaded rosy pink. Pkt., 3 cts.; $0 z ., 8$ cts.

Ft. Chase, Pa., Jan., 1900.-My seeds from you last year were a success. Sweet Peas especially were a show. Poppies, pinks and Nasturtiums also were fine."

So. Bristol, Me., April 4, 1900, - "Your Sweet Peas are by far the finest we have ever raised." MBS. J. W. Farsce. 
My 50 Varieties Mixed.

This is my choicest mixture and includes only the 50 named varieties described on the preceding pages. It contains the cream of the late novelties and established standard varieties, and is offered as a convenience to those who do not care for so large a quantity as a packet of each kind. Pkt., 4 cts.; $0 z, 10$ cts.; $1 / 4$ lb., 30 cts.; lb., \$1.

\section{American Seedling Sweet Peas.}

This splendid mixture has given the greatest satisfaction. The Florists' Exchange says of it: "This is the most remarkable strain of Sweet Peas ever produced," and I can fully endorse this high commendation. It contains flushed and solid shades of white, buff, pink. rose, fiery scarlet, etc., the prevail ing colors being light. Mixed. Pkt., 4 cts.; $\mathrm{oz}$ 10 cts.; $1 / 4$ lb., 25 cts.; lb., 90 cts.
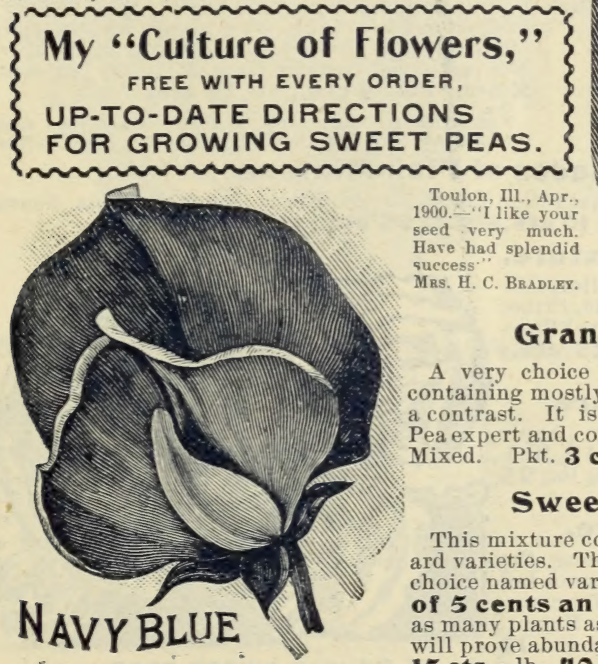

Toulon, III., Apr. 1900.- "I like your seed very much Have had splendid success MrS, H. C. BEAdLEY.

\section{Grandiflora Sweet Peas.}

A very choice mixture of only large-flowering types containing mostly light-colors, with just enough dark for a contrast. It is the result of hybridizing by a Sweet Pea expert and contains many of the expensive novelties. Mixed. Pkt. 3 cts, oz. 8 cts, $1 / 41$ lb. 20 cts, $1 b, 65$ c.

\section{Sweet Peas, Good Mixed.}

This mixture contains a beautiful assortment of stand ard varieties. The seed is what I have left over from my choice named varieties and is offered at the low price of 5 cents an ounce, This will give several times as many plants as would an ordinary 5 cent package, and will prove abundantly satisfactory, $\mathrm{Oz} ., 5$ cts.; $1 / 4 \mathrm{lb}$., 15 ets.; lb., 40 cts.

\section{Everlasting Sweet Peas.}

The blossoms of the perennial Sweet Pea appear in large, graceful clusters, in white and rose shades, and last throughout the summer. This seems especially adapted to those southern latitudes and regions where the annual Pea fails, though it is perfectly hardy anywhere. Mixed, white and rose. Pkt., 4 cts.

\section{Dwarf Cupid Sweet Peas.}

To accommodate those who would like to try the new dwarf Sweet Peas-the Cupids-1 offer a mixture containing Alice Eckford (creamy white suffosed with soft flesh-pink), Beauty (rose color) Pink. Pimrose and White. Five varieties mixed, Pkt., 5 ets., Oz.: 25 ets.

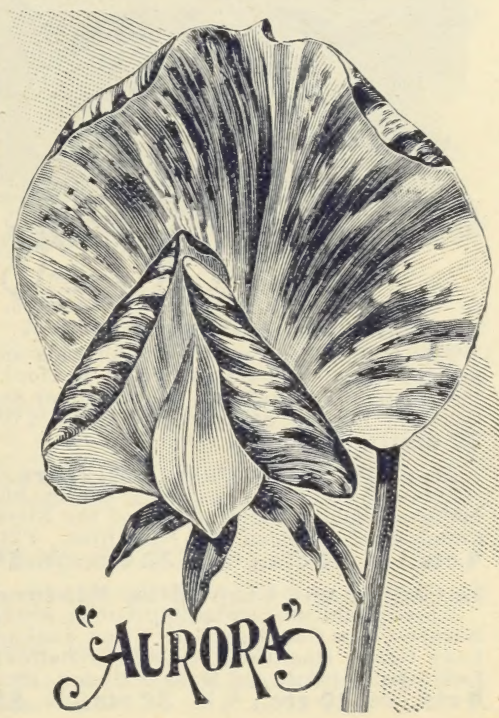




\section{SWEET PEA MIXTURES.}

For the many who prefer particular colore in Sweet Peas, rather than a general mixture, I offer special mixtures, made up from my choice named varieties. See pages 3 and 4.

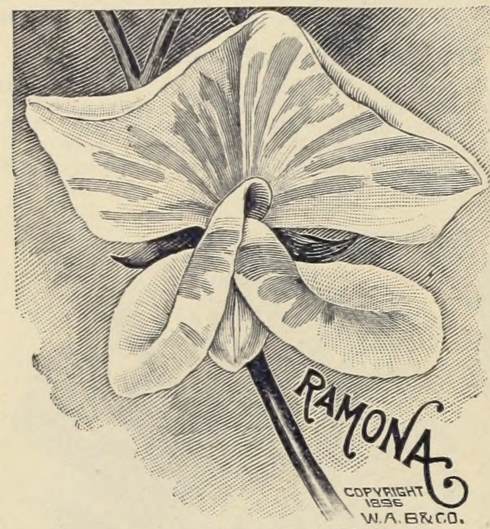

Claret and Maroon Mixture.

This includes the popular Shahazada and Stanley varieties, and also two of Eckford's just introdnced. Duke of Westminster and Othello. Pkt., 4 cts.; oz., 10 cts.; $1 / 4$ lb., 30 ets.; 1 lb., \$1.00.

Dark Blue and Purple Mixture.

This affords the richest dark shades, and includes Black Knight, Capt. of the Blues, Countess of Cadogan and Navy Blue. Pkt., 4 ets.; oz., 10 cts.; $1 / 4$ lb., 30 cts.; lb., \$1.

Lavender and Light Blue Mixture. A lovely mixture, containing Crown Jewel, Burpee's New Countess, Gray. Friar, Juniata, Lady Grisel Hamilton, Lady Nina Balfour, Lady Skelmersdale and Maid of Honor. Plt., 4 ets.; oz., 10 cts.; $1 / 4$ lb., 30 cts.; lb., \$1.

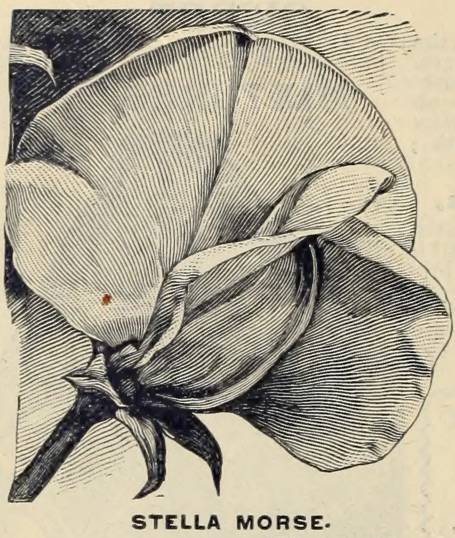

Red Mixture.

This includes Mars, Prince Edward of York, Salopian. Pkt., 4 cts., oz., 10 ets., $1 / 4$ lb., 25 cts., 1 lb., 90 ets.

White Mlxture.

This includes the well known varieties, Blanche Burpee and Emily Henderson, and the new white, Sadie Burpee. My grower says of this: "Customers often fail with white sweet peas, but with proper care the seed should yield a large percentage of plants." My "Culture of Flowers," free with every order, gives special directions for this class. Pkt, 4 cts., oz. 10 cts.. $1 / 4$ lb. 30 cts., lb. $\$ 1$.

New Double Sweet Peas.

Although the so-called Double Sweet Peas are not much more than semi-double, they are very distinct and beautiful. The plants are unusally vigorous and produce a profusion of flowers. Not all come double-from 25 to 50 per cent. Mixed. Pkt., 4 ets., oz., 10 ets.

North Yakima, Wash., Apr., 5, 1900.- "I find your seed splendid, and the Culture book very valuable. Mrs, G,W Stice.

\section{Light Shades of Pink Mixture.}

This includes Hon. F. Bouverie, Katherine Tracy, Lovely, Prima Donna, Ramona, Sensation and Venns. Pkt., 4 cts.; oz., 10 cts.; $1 / 4$ lb., 25 cts.; 1 lb., 90c.

Deep Pink and Rose Mixture.

This includes Captivation, Chancellor, Colonist, Her Majesty, Mrs.Dugdale, Ovid, Prince of Wales, Red Riding Hood and Royal Rose. Pkt., 4 cts.; oz., 10 cts.; $1 / 4$ lb., 25 cts.; 1 lb., 90 cts.

Pink and White Mixture.

A mixture of popular varietics, Apple Blossom, Blanche Ferry, Earliest of All, Mod esty. Pkt., 4 cts.; oz., 10 cts.; 1/4 lb., 25 ets.; lb., 90 c.

\section{Salmon Pink Mixture.}

Salmon or orange pinks are among the handsomest of the Sweet Peas and cannot fail to please. Countess of Powers, Gorgeous, Lady Mary Currie, Lady Penzance, Meteor, Oriental, Triumph. Pkt., 4 cts.; oz., 10 ets.; $1 / 4$ lb., 25 cts.; 1 lb., 90 cts.

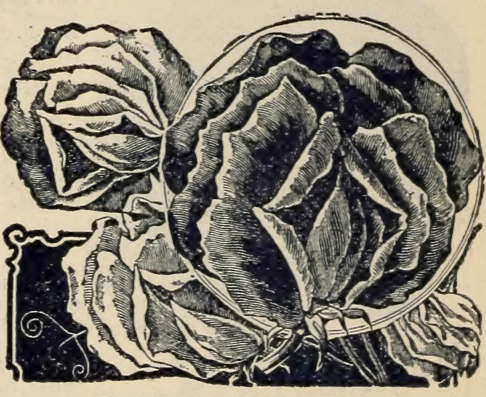

DOUBLE SWEET PEAS. 


\section{ASTERS....}

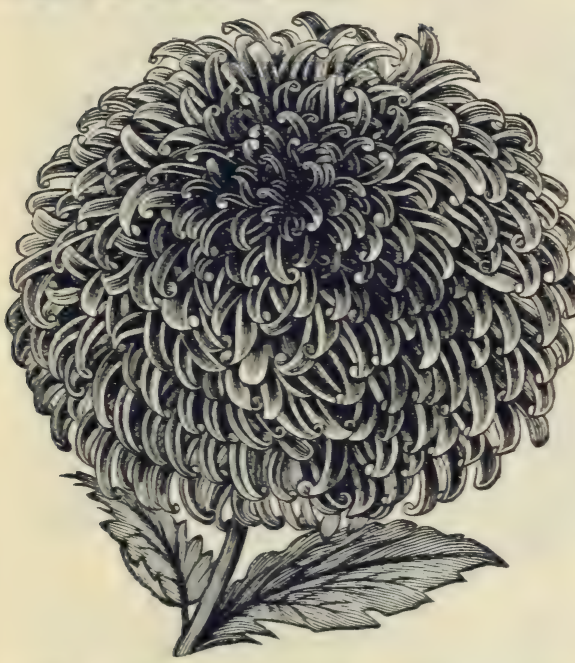

New Giant Branching Comet Aster

A grand new Comet Aster. The flowers are very large, sometimes measuring six inches in diameter, and the petals are so twisted and curled as to give a decidedly Chrysanthemum effect. The flower-bearing stems are long and splendid for cutting. The originator claims that there are "no handsomer $\mathrm{As}$ ters in existence." Like the ordinary Comet, they are early flowering, hence should be sown with late varieties to give a succession of bloom. Mixed. Pkt. 5 cts.; 2 pkts., 8 cts.

Tecnmseh, Neb.. Mar., 1900.— "I was well pleased with my flower seed last year, and hzd some of the finest Asters I ever saw.
I beg special and careful attention to my $1901 \mathrm{As}=$ ter list. It includes the cream of the standard varieties, and the seed, which is grown for me by an aster expert, I guar= antee to be unsurpas: sed in germination and quality and style of flowers. A few of many testimonials voluntarily sent me are given, and I should be glad to print all such expressions of satis faction did not lack of space forbid.

No better Aster mixture on the market than my Imperial Aster Mix ture. It contains all my named varieties. See p. 9

Syracuse, N. Y., March, 1900.-
"My Asters from your seed were admired very much. LENA Schutesser.

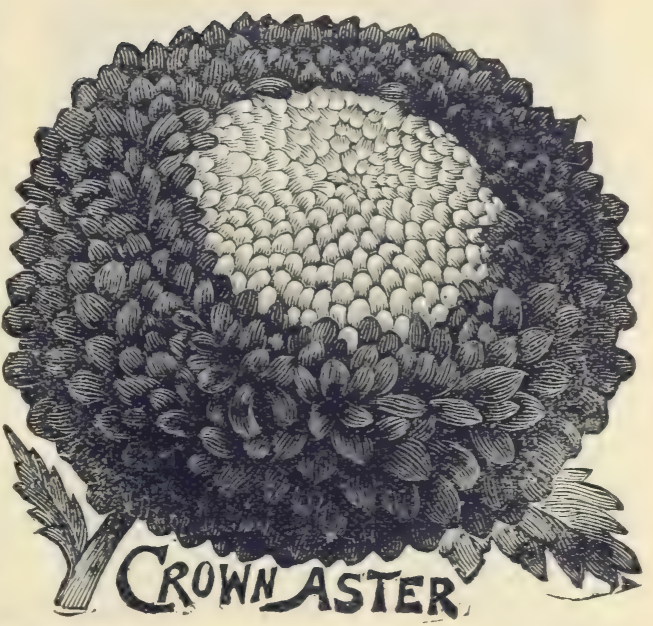

New Crown or Cocardeau Aster.

A very attractive variety, bearing great numbers of densely double flowers, each having a white center, with a wide margin of some brilliant color. Pkt., 4 cts.; 2 pkts., 7 cts.

\section{Dwarf Chrysanthemum Aster.}

In size of flowers and habit of growth, no dwarf variety is more desirable. The flowers are large, chrysanthemum-shaped, and produced in clusters of fifteen to twenty, or even more, in a truss, each plant forming in itself a beautiful bouquet. It will be found very useful for edgings, beds and for pot culture. Mixed. Pkt., 4 ets.; 2 pkts, 7 cts.

\section{Imbrique Pompone Aster.}

A free flowering Aster, of compact, branching habit. The flowers are densely double and beautifully imbricated. Mixed. Pkt., 4 cts.; 2 pkts., 7 ets.

\section{Ostrich Plume White Aster.}

A lovely white Aster of the Giant comet type, so named because of its long curling petals. Pkt., 6 ets.; 2 pkts., 10 cts. 


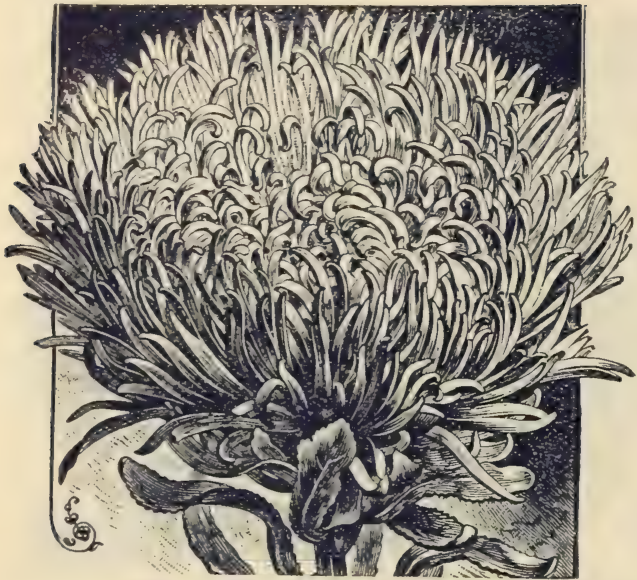

New Japanese, or Tassel, Aster.

A distinct new type. The flowers are very large, measuring five or six inches across and have long, curionsly waved and twisted petals. A single plant often has forty or fifty flowers, which are borns on long stems and resemble somewhat the well known Japanese Chrysanthemums. Colors, soft flesh pink and rose. Pkt., 5 cts.; 2 pkts., 8 cts.

\section{California Giant Silver=Tipped Aster.}

A new Aster of great beauty. The plants are rugged and branching, and bear elegantly formed double chrysanthemum-like flowers, the petals being broad and slightly recurved. The tip of each petal is tipped with silvery white, contrasting beautifully with the brilliant blue or rose pink beneath, and making a very striking flower

Silver $=$ Tipped, Blue Aster, Pkt., 6 cts.

Silver=Tipped, Pink Aster, Pkt., 6 cts.

Victoria Aster.

One of the most desirable strains and much used by florists. The petals curve outward and overlap each other regularly, and when the plant is in bloom the foliage is completely hidden by the massive flowers. Mixed. Pkt., 4cts,; 2 pkts., 8 cts. Victoria, blue shades, Pkt., 4 cts.; Vic= toria, rose 8 hades, Pkt., 4 cts.; Victoria, white, Pkt., 4 ets.
ASTERS

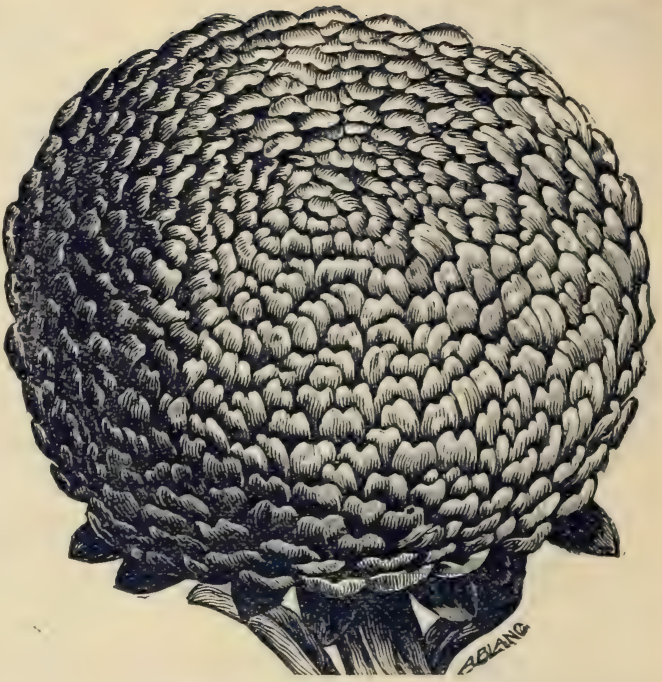

Jewel, or Ball, Aster.

This variety is somewhat after the Peony Perfection type, with petals incurving, forming handsomo ball-shaped flowers, splendid for cutting. The plant is tall and much branch$\epsilon d$ and a great bloomer. Mixed. Pkt., 5 cts.; 2 pkts., 8 c.

\section{Prize Quilled Aster.}

This variety is unlike any other in that the petals are tube or quill-shaped, bunched in a dense mass, surrounded by an involucre of ordinary shaped petals. The plants are tall and bear a great profusion of blossoms, which remain perfect many days after cutting. Mixed. Pkt., 4 ets.; 2 pkts., 8c.

Neligh, Neb., Sept.; 1900.- "I wish you could see my Aster bed this fall. I planted them in a hot bed and every seed came up, and now they are the wonder of the town-so large and so many varieties of color. My heliotrope, pinks and verbenas have done finely." 


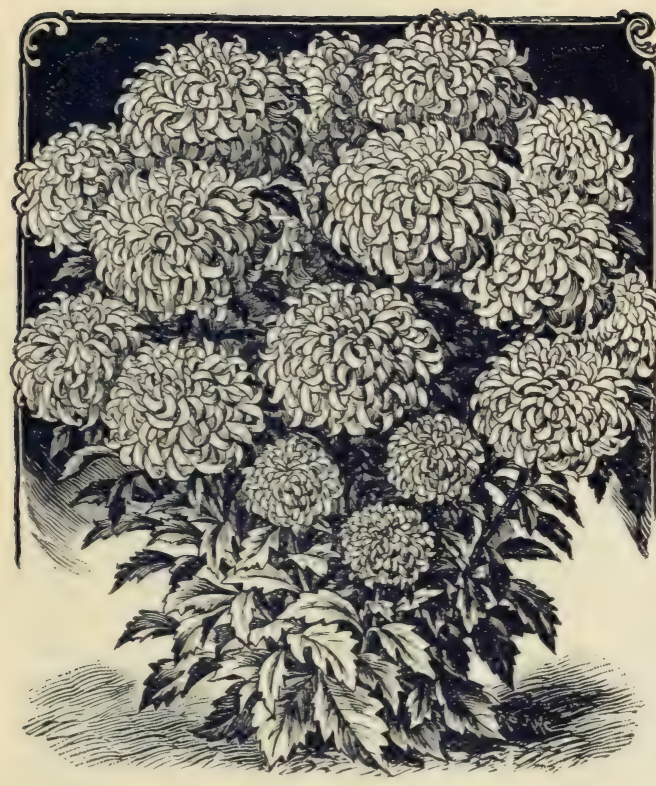

Semple's Branching Aster.

The handsomest strain of Asters grown, especially prized by florists. The flowers are large, chrysanthemumshaped and very double, and without the stiffness somesomewhat characteristic of the Aster family. Coming late, they prolong the Aster season until frost. A single plant will produce twenty or more flowers. Mixed. Pkt., 5 ets.; 2 pkts., 8 cts.

Semple's, dark blue, Pkt., 4 cts.

Semple's, lavender, Pkt., 4 cts.

Semple's, pink, Pkt., 4 cts.

Semple's, white, Pkt., 4 cts.

\section{ASTERS.}

\section{Truffaut's Paony Perfec= tion Aster.}

The most noted of all the Asters. The flowers are very double and of great size, which with their beautifully incurv ed petals gives a perfec-
tion of form unsurpassed in any other variety. The fiowers are splendid for cutting, and the range of colors is exceedingly wide. Truffaut's Perfec tion is the latest improvement of this most desirable Aster. Mixed. Pkt., 4 c.; 2 pkts., 7 c.

\section{Mignon Aster.}

A new class semi-dwarf in habit, one of the best for cut flower use. Each plant bears from 40 to 50 blos

lar Victoria Aster, though somewhat smaller. Mixed. Pkt., 4 cts.;2 pkts., 7c.
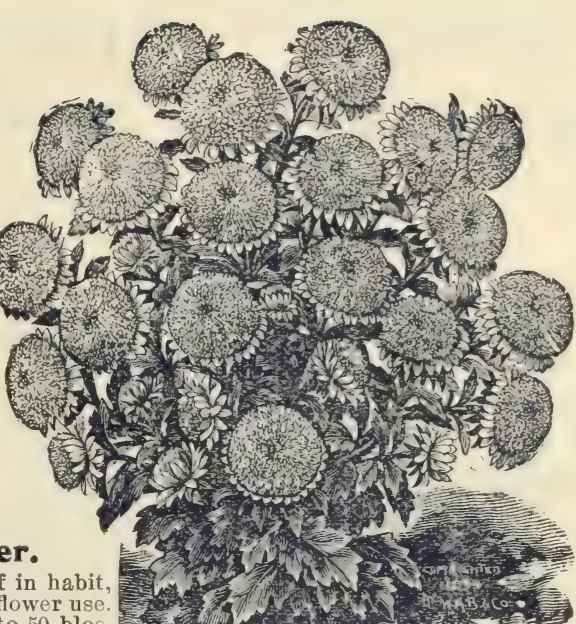

\section{Yellow Aster.}

The only really yellow Aster yet developed. It belongs to the quilled Aster group, having quills of bright sulphur yellow, densely crowded together and encased by a frill of petals of lighter shade. Plant, twelve to fifteen inches high, with its abundant blossoms borne on long stems, excellent for cutting. Pkt., 5 cts., 2 pkts., 8 cts.

\section{Imperial Aster Mixture.}

For those who would like to try all of my fifteen varieties I offer a mixed packet, containing all of these in equal proportion. A packet of this mixture will surprise you with almost every shade of Aster grown, iriving early and late bloomers, and many styles and shades of flowers. IIy Asters in the past have received many compliments, and I feel sure no other mixture will give better satisfaction. Pkt., 5 cts., 2 pkts., 8 cts.

Asters, Good Mixed. A choice mixture of many varieties in all the leading Aster colors. Pkt., 3 cts., 2 pkts., 5 ets.

collection of Asters. One packet of each of my fifteen varioties-fifteen packets in all $\rightarrow$ of the choicest Asters grown, 45 cts 
ALPHABETICAL LIST OF...

\section{CHOICE}

\section{FLOWER SEEDS...}

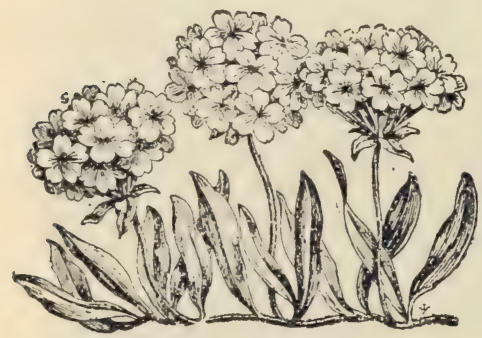

Achillea Ptarmica.

A beautiful plant, bearing in great pro fusion large clusters of double flowers, pure white, giving the plant appropriately the name of "The Pearl." It blossoms al summer and is invaluable for floral pieces, bouquets, and fine for cemetery "planting, as it is perfectly hardy and readily takes care of itself. Perennial. Pkt., 5 cts.; 2 pkts., 8 cts.

Arlington, III. Feb., 1900.- "Your seeds are the cheapest I have ever tried, and come good. My early cheapest have ever tried, and august and until frost killed them. The Giants of California Petunias were fine, both double and single. One white one measfine, both double and single., One white one meas.

\section{Abronia Umbellata.}

A beautiful trailing plant from California. The prostrate branches bear clusters of sweet scented, rosy-lilac flowers, resembling somewhat the verbena, only they are much more delicate. The blossom is especially fragrant towards evening. Annual. Pkt., 3 ets.

\section{MY CULTURE OF FLOWERS FOR 1901.}

Gives directions for growing all the seeds listed in my Catalog, with special instructions for Asters and Sweet Peas.

A copy sent Free With Every ORDER.

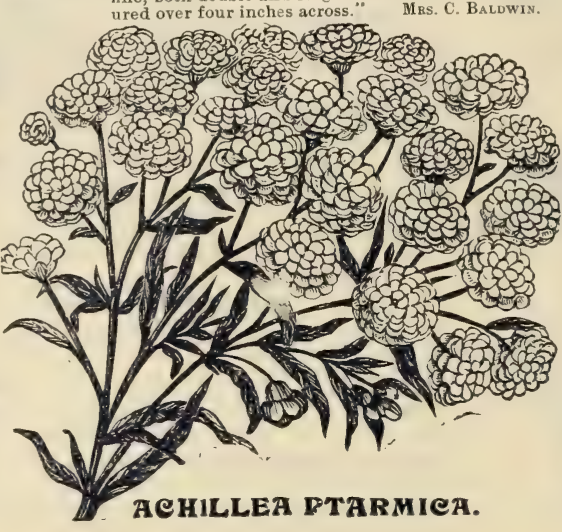

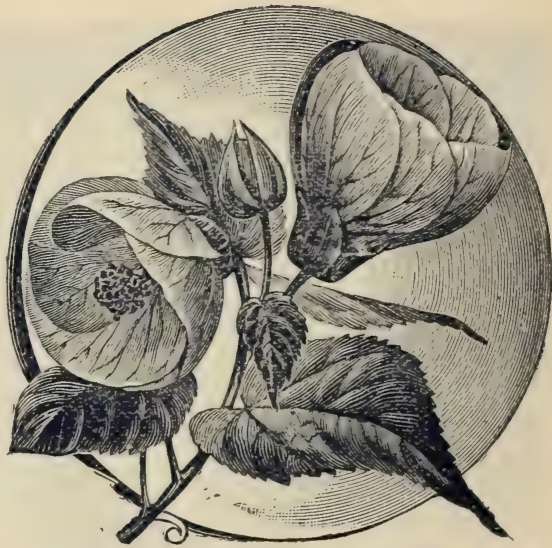

New Hybrid Abutilon

(Flowering Maple).

The florists advertise each year new and desirable varieties of these always popular plants, but the seed here offered will give as choice a selection, being grown from many of the newer and charming kinds. The colors range from pure white, straw and yellow, o rose, crimson and scarlet, with the beautiful reins and markings peculiar to these delicate bell-like flowers. They bloom from seed when ten or twelve inches high. Mixed. Pkt., 6 ets.

\section{Abrus Precatorius}

\section{(Crab's Eye Vine).}

The Prayer Bean, a handsome climber for pot culture or for the open ground in summer. It bears clusters of purple butterfly-shaped flowers, but is chiefly remarkable for its bright scarlet seeds, with black eyes, which are used for ornamental purposes and for rosaries. Tender perennial. Pkt., 4 cts. 


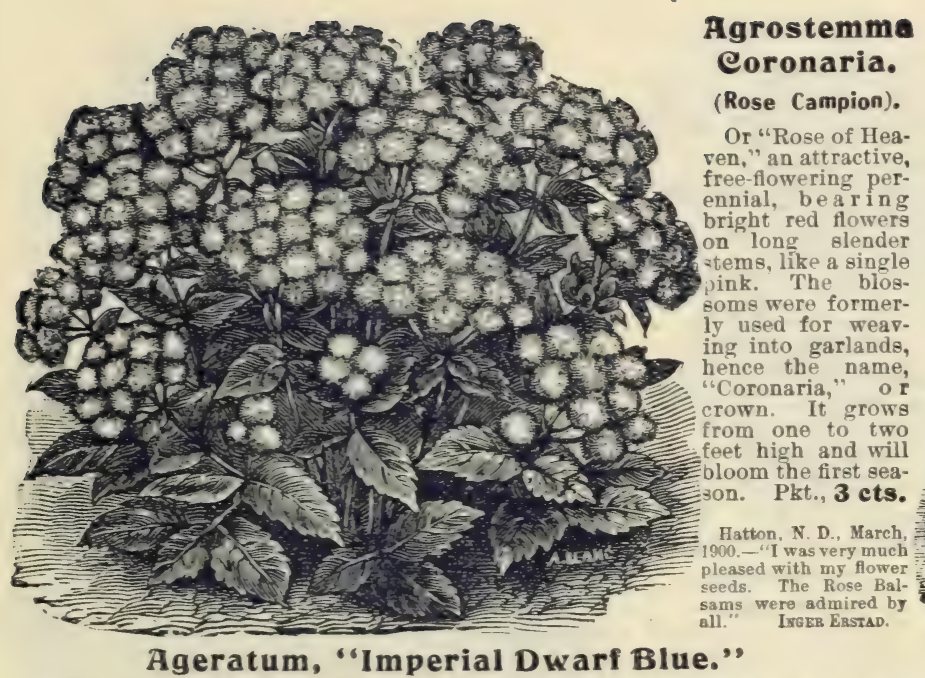

Every one knows this popular edging plant, but all do not know that it grows readily and quickly from seed. Even when sown in the open ground in May it comes into flower soon enough to answer it a purpose the same season, and if sown in August it makes nice pot plants for winter. A few cents will furnish enough plants for a border for a large bed, which will be dotted throughout the season with pretty blue. brush-like flowers. The "Imperial Dwarf Blue" is one of the prettiest varieties and freest bloomers. Tender perennial. Pkt., 3 cts.; 2 pkts., 5 cts ; ${ }^{1 / 4}$ Oz., 15 cts.

\section{Ageratum, "Swanley Blue."}

A fine, very large flowering, dwarf variety, with flowers of deep azure blue. Very pretty. Pkt., 3 cts.

\section{Anchusa Capensis.}

A hardr biennial, bearing handsome blue, forget-me-not like flowere. It thrives in shadr, out-of-the-war places where nothing else will grow. The flowers are of a clear deep blue, with a white center, and are desirable for cutting. The blooming season is long continued. Pkt., 3 cts.

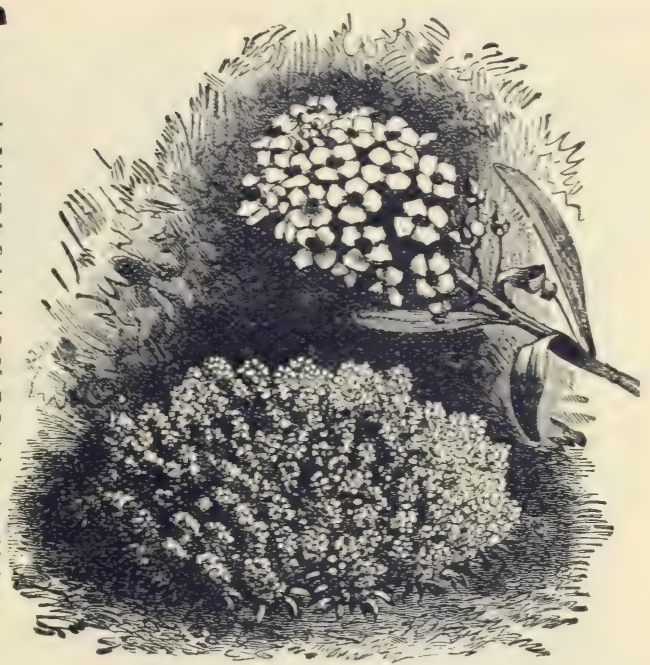

\section{Little Gem Alyssum.}

Splendid for cemetery planting or for edgings. The plants arc dwarf and compact, a single plant covering a space from 15 to 20 inches in diameter. The single flor et. are larger and more closely crowded on the flower sf it than in the common Alysium, making a showier blossom and converting the plant into a mass of white, which remains in full bloom throughout the season.

Pkt., 4 cts.; 2 pkts., 7 cts.; ${ }_{-1} \mathrm{Oz}$., 15 cts.

\section{Sweet Alyssum}

\section{Benthami).}

If desired for cutting, this, the common Sweet Alyssum. is the variety to sow. The long spikes of delicate white touch off a bouquet of Nasturtiums. Pansies or other coarser flowers, giving a finish and delicateness they do not have when massed alone.

Pkt.. 3 cts.; 2 pkts.. 5 cts.; ${ }^{1} \div$ OZ.. 10 cts. 


\section{New Amaranthus, “Brilliant"}

This is a hybrid of Amaranthus Tri-color. and is unquestionably the most beautiful of this class The leaves are brilliantly colored a variegated red, which with its crimson-rose. red and yellow-tinted head produces a gorgeous effect. The plant does not have the rank growth of the ordinary Amaranthus, but grows more like coleus, and in fact is a splendid substitute for the latter and well deserves a place in the foliage bed. Pkt., $\mathbf{3}$.

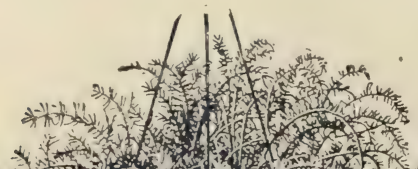

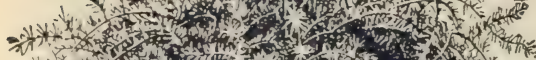

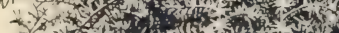

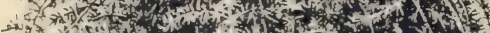

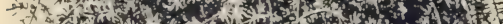

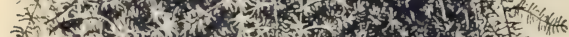

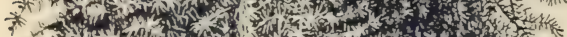

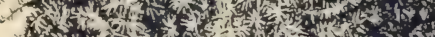

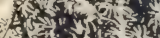

\section{*⿻十⺀㇂ \\ whe}

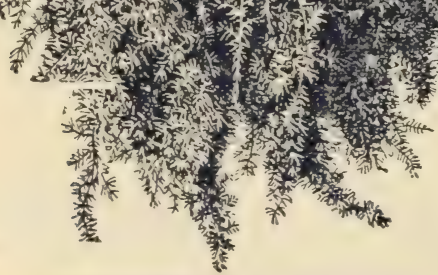

ASPARAGUS SPRENGERI.

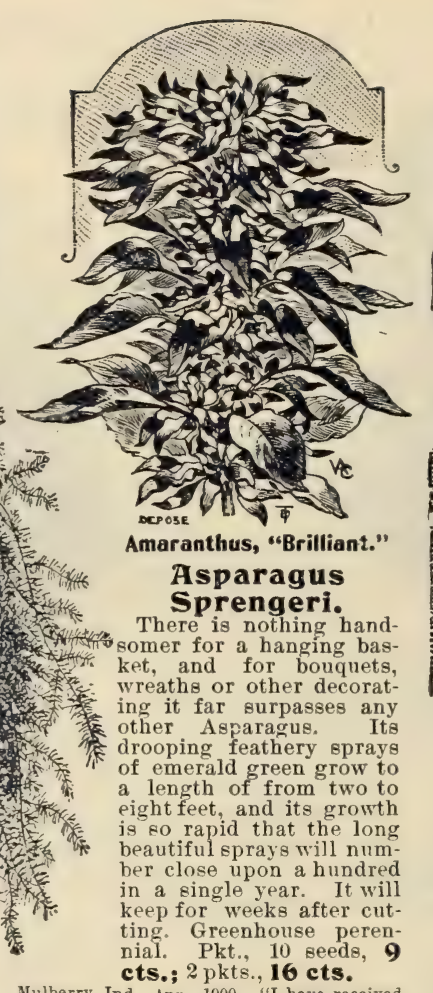

Mulberry, Ind., Apr., 1900._."I have received many catalogs, but yours being from a woman I thonght I would try your seed, and because Hattie F. Steckel.

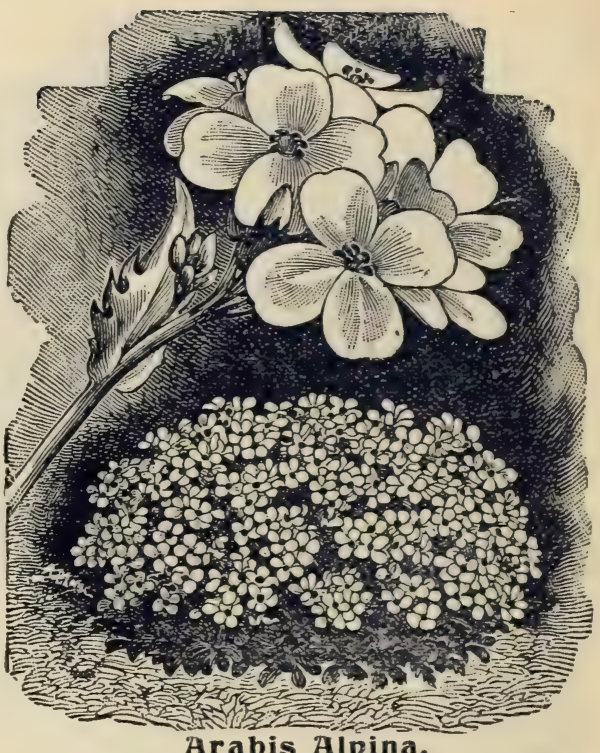

A very hardy perennial, specially prized because it comes so early in the spring, its bright silvery green foliage being covered by a sheet of white flowers almost as snon as the snow disappears. It is useful also for edgings, as the plant is low growing, and the silvery rreen leaves give a pleasing effect, even when it is not in bloom. Pkt., 3 cts.

\section{Anemone Coronaria}

(St. Brigid's Poppy.

A hardy perennial, producing large brilliant flowers, single, semi-double and donble, maroon. scarlet, pink, liÎac and purple. Pkt.. 4 ets. 


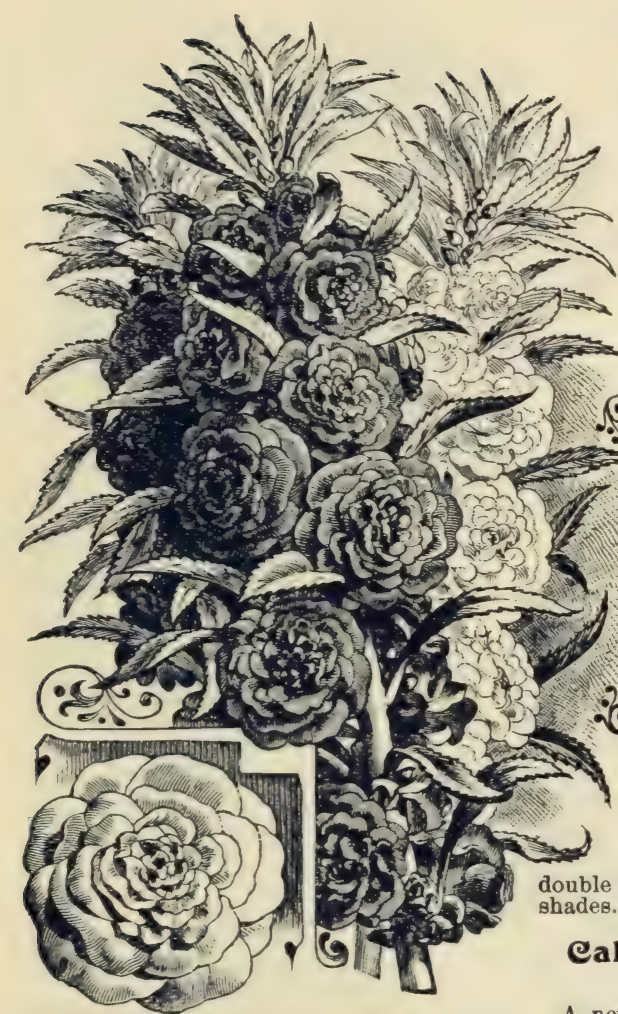

Improved Rose Balsam.

A splendid strain of largest size and extreme doubleness, incl u d in named varieties, selected to give a great variety of beautiful shades, viz., in solid colors, crimson, flesh, lilac, rose, scarlet, violet, white, etc., including also the Camellia, or spotted Balsams, the blossoms being on white ground, mottled in many shades. Give the plants sun, good soilnot too rich-and plenty of room. If they branch freely, prune them out. The fewer the branches the larger the blossoms. Mixed. Pkt., 5 cts.; 2 pkts., 8 cts.

\section{New Balsam,} Aurora.

The flowers are densely double, a beautiful salmon-pink color, and so - crowded on the stalk as almost to hide the foliage. One of the finest named varieties. Pkt., 5 cts.

Balsam, Good Mixed.

A choice mixture of

IMPROVED ROSE BALSAK.

California strain which sorts, with beautiful foliage and splendid large flowers. Pkt., 6 cts.

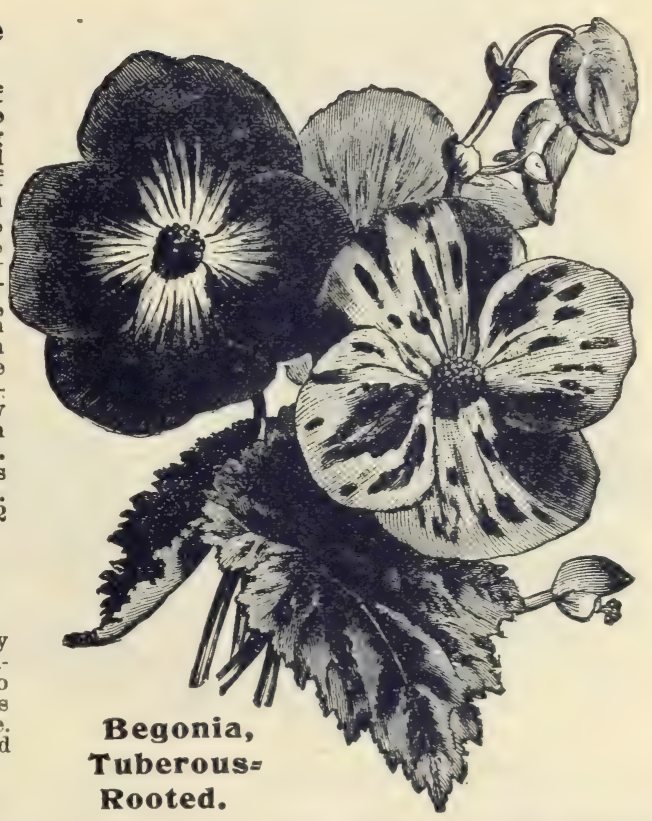

The Tuberous-Rooted Begonias have gained great notoriety for their large and showy blossoms. Blooming only in the summer time, they are fine for bedding, or for making brilliant the conservatory window at a time when most house plants are resting. For bedding. select a shady situation, and they will give a magnificent display throughout the summer. Mixed, double and single.

Pkt., 7 cts.

Golden $=$ Variegated Vernon Begonia. Choice new Vernon variety, yellow variegated foliage. Pkt., $6 c$. Begonia, mixed. All my three varieties mixed, Pkt., 6 cts. 


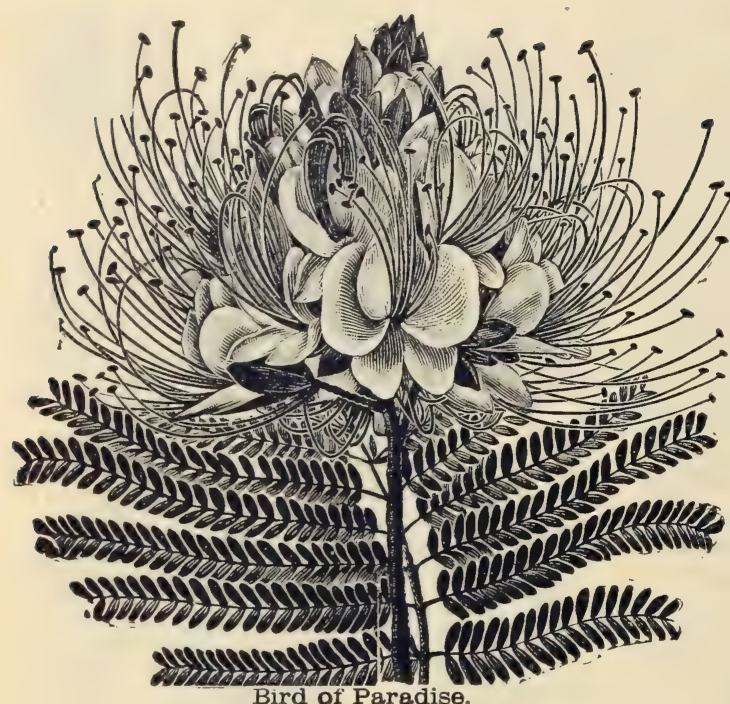

Bird of Paradise (Poinciana Gillesi).

An attractive plant, with large golden-yellow flowers. The flowers are produced in large compact trusses, from which the crimson stamens spread out in a peculiar, fan-shaped way, very striking and showy. The foliage is also very beautiful and highly decorative, similar to the acacia. Greenhouse perennial, except in the South, where it is hardy. Pkt., 4 ets.

\section{Balloon Vine.}

A rapid growing, annual climber. It bears small white flowers, not particularly showy, but the vine grows rapidly and makes a fine sereen, and bears curious, inflated seed pods, like small balloons, making it both desirable and interesting.

Pkt,, 3 cts.

Brachyce ome.

(SwanRiver Daisy.)

A pretty little plant bearing

charming Ciners, blue, white or rose. The foliage is finely cut and very pretty, and the plant is a free bloomer, blossoming quickly from seed. It grows to a height of from 6 to 10 inches, and is pretty for bedding, pots or rustic work. Half hardy annual. Mixed. Pkt., 3 cts.

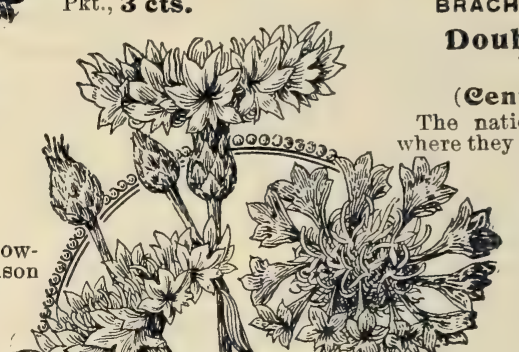

\section{Double Bachelor's} Button

(Centaurea Cyanus).

The national flower of Germany iv sus (10000333 where they call it the "Corn Flower" or "Kaiser Blumen:" also known as "Blue Bottle." and "Ragged Sailor." This old-fashioned flower bas come again into great popular favor; artists paint it, ladies use it for the corsage and it is prized for cutting. Mixed, many beantiful colors. Pkt., 3 cts.; 2 pkts., 5 cts.

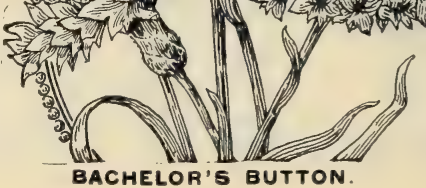

Bachelor's Button.

“Emperor William."

As there is so much call for blue Bachelor's Button, I offer this special variety, a rich deep blue. Pkt., 4 ets. 
Byng Inlet, Ontario "I have tried your seeds and find them good. don thelieve there was good, and this is a poor climate for flowers."

climate for flowers.
Mrs. Joe Benner

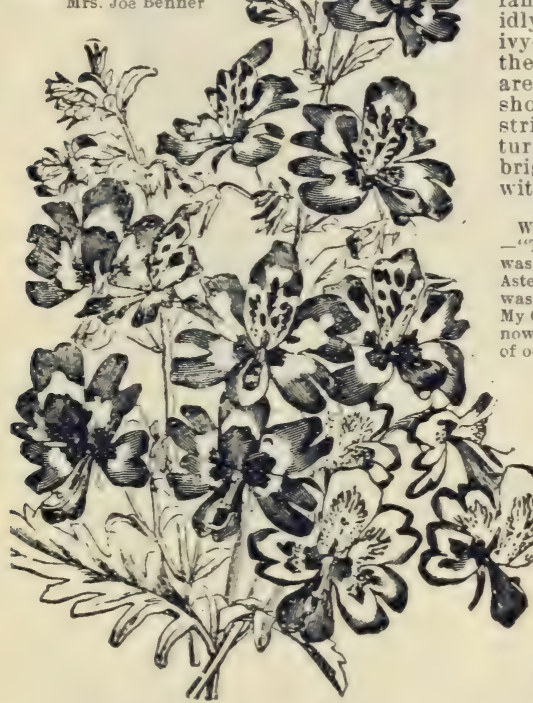

Butterfly Flower

(Schizanthus).

These are charming little plants, with delicate flowers of white, pink, lilac, or purple, curiously marked with crimson, lilac, purple and yellow blotches, all resembling a miniature butterfly. They are very pretty to mass together ог to combine with coarser flowers in decorating a bouquer. Annual. Mixed. Pkt., 3 cts.

\section{Bryonopsis}

Laciniosa.

$A$ beautiful annual climber of the gourd family. It grows rapidly, bearing pretty, ivy-shaped leaves and the yellow blossoms are followed by a showy fruit, first green striped with white, turning when ripe to bright scarlet marbled ith white. Pkt., 4c.

Wateploo, Ont., Apr., 1900. "The seed I got from you was very satisfactory. The Asters were beautiful. There was nothing here like them. My Calceolarias are blooming now, and are very lapge and Katie Becker. Decatur, III., Jan. 20 ,
1900.-"One of my neighbors was so delighted with my flow ers last year from your seed that she has joined with me this spring Mrs. E. J. Brewster.

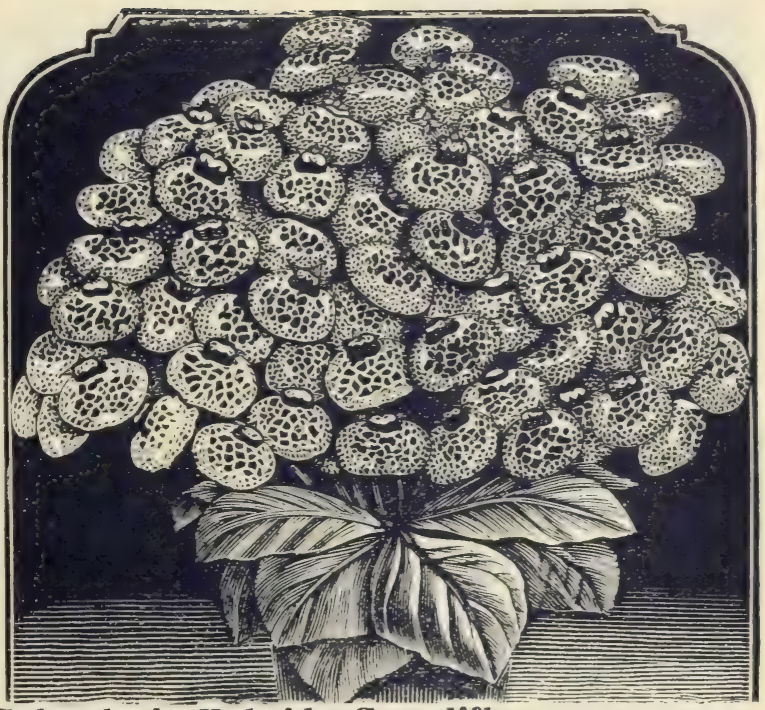

Calceolaria Hybrida Grandiflora.
These are gorgeous plants for the greenhouse or window. remarkable for their orchidlike blossoms and not difficult to raise from seed. They come into flower eight months after sowing, bearing hundreds of curious pocket-like flowers, beautifully spotted and margined. Greenhouse biennial. Pkt., 6 cts.; 2 pkts., 10 cts.

\section{Cacalia Coccinea.}

The "Tassel Flower " or "Flora"s Paint Brush." A pretty annual with brush-like flowers; blooms from June to September. Flowers in golden yellow and bright scarlet. Mired. Pkt., 3 ets.; 2 pkts., 5 cts.

\section{Centrosema Grandiflora.}

"Look-at-me-Vine" or "Butterfly Pea," a beautiful hardy perennial vine. It reaches a height of 7 to 8 feet the first season and bears beautiful clusters of 6 to 8 inverted peashaped flowers, $1 \frac{1}{2}$ to $2^{1 / 2}$ inches across. These are of a rosy violet hue with white markings through the center, while the backs of the blossoms and the buds are pure white. making a striking contrast. Arranged with their foliage, they are fine for cutting. Pkt. 4c. 


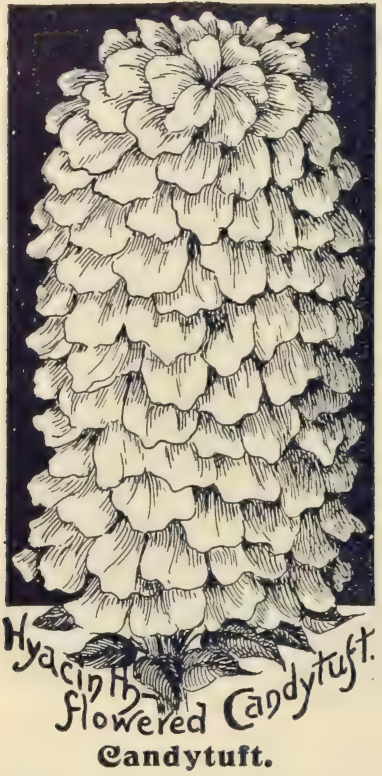

Giant Hyacinth-Flowered. This is an improved Rocket or Emppress Candytuft, bearing immense flower heads, sometimes six inches long and from two to three inches in

diameter. The florets are pure white and of unusual size. A plant has from four to nine branches, each crowned with a bunch of these magnificent flower spikes.

Pkt., 4 cts.; 2 pkts., 7 cts.; $1 / 4$ oz., 15 cts.

Rocket, or Empress Candytuft. Large showy heads, splendid for floral designs or for cutting. Pkt., 3 ets.: 2 pkts., 5 cts.; $1 / 40 z ., 10$ ets.

Umbellata Candytuft. Beautiful carmine shades. Pkt., 4 cts.

Candytuft, Mixed. Above three varieties mixed. Pkt, 3 cts.; 2 pkts, 5c. Iberis Gibraltrica. A hardy perennial Candytuft. Pkt., 4 cts.

These ornamental foliage plants with their mired. Although perennial, the plants grow rapidly and attain perfection the first summer. The leaves are large and curiously newest and most beautiful varieties. Mixed. Pkt., 8 cts.; 2 pkts., 12 ets.

\section{New French Coleus.}

A fine mixture of French hybrids, sure to give only choice varieties. Pkt., 5 cts.; 2 pkts., 8 cts.

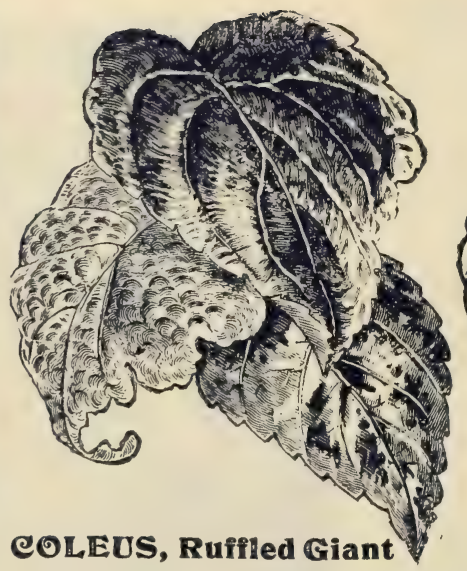

2 single plant, bearing from 100 to 200 blossoms.

Pkt., 4 cts.

Canterbury Bell, single mixed, Pkt., 3 cts. Canterbury Bell, double mixed. Pkt., 3 ets. canterbury Bell, mixed. A mixture of above three varieties. Pkt., 3 cts.; 2 pkts., 5 cts.

So. Brooklyn, O., Mar., 1900.- "My seeds arrived all right. Cosmos, Canna, Cobea und Mina Lobata are all up and growing fine- 


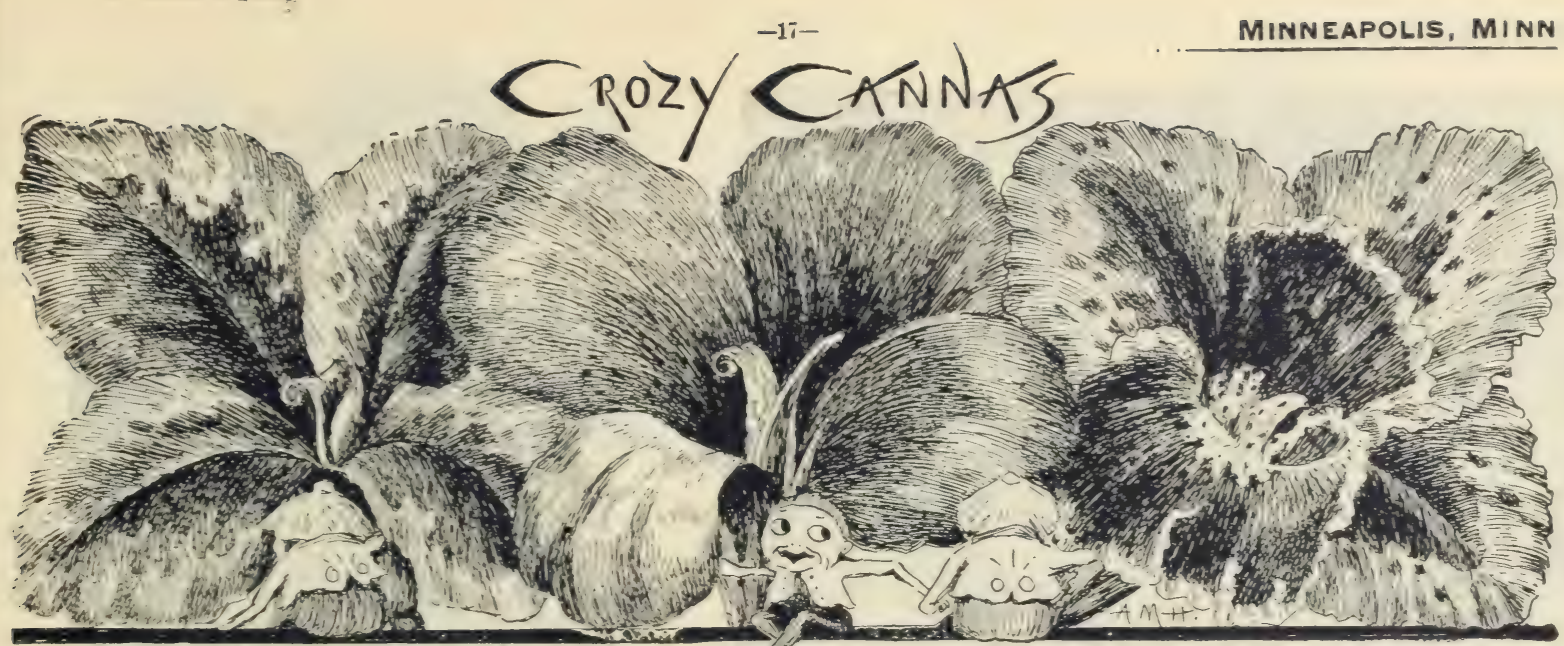

Madam Crozy Dwarf Canna.

Formerly cultivated principally for its imposing stateliness, but in its dwarf forms with their crowded spikes of greatly enlarged Gladiolus-like flowers, the Canna is now a great favorite on account of the beauty of its blos soms. It is easily raised from seed and blooms the first season. Keep the roots in the cellar over winter and there will be an abundance for next year's planting. My "Culture of Flowers," free with every order, gives ful directions for growing from seed. Pkt., 3e.; 2 pkts, 5c.

\section{Castor Bean}

\section{Ricinus).}

A mixture of two of the newer and most desirable var ieties. ZAXZ'BARFX-Is and 'AMBODGEXsis. In the former the leaves are light green, coppery brown or bronze colored. Those of the latter are bronzy maroon, with dark Teins and stems. Pkt., 4 ets.

\section{Canary Bird Flower.}

A splendid climber for the porch or trellis. It grows tapidly, has very pretty foliage, and curiously-shaped, grolden yellow flowers. Annual. Pkt, 4 cts.

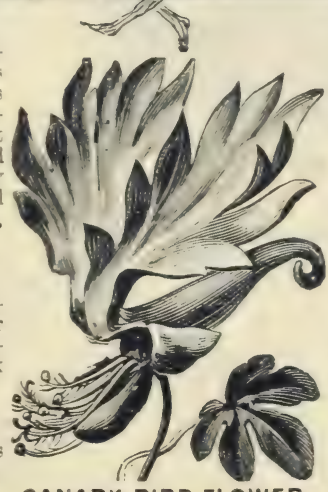

Florence Vaughan Canna.

One of the finest yellow spotted varieties. The color is a rich golden yellow, spotted with bright red. The flowers are of the largest size and borne in large, full heads in great profusion. Pkt., 5 cts.

Bronze-Leaved Canna. A mixture of the dark-leaved varieties. Pkt., 5 cts.

Mixed Canna. My three varieties mixed. Pkt., 4 ets.; 2 pkts., 7 ets.

COLUMBINE (Aquilegia).

Coming rery early before many other flowers are blooming, the Columbine is an essential feature of the perennial bed. The flowers are of curious formation, in some the spurs being developed to a great length. They come in both single and double flowers, and it is hard to tell which is prettier. I offer a very choice mixture, containing the Coerulea, a pretty blue and white, the Chrysantha, a long-spurred yellow variety, having a very long period of bloom, double white and many other desirable varieties. CANARY BIRD FlOWER. Double and single, mixed. Plit., 4 cts.; 2 pkts., 7 c. 


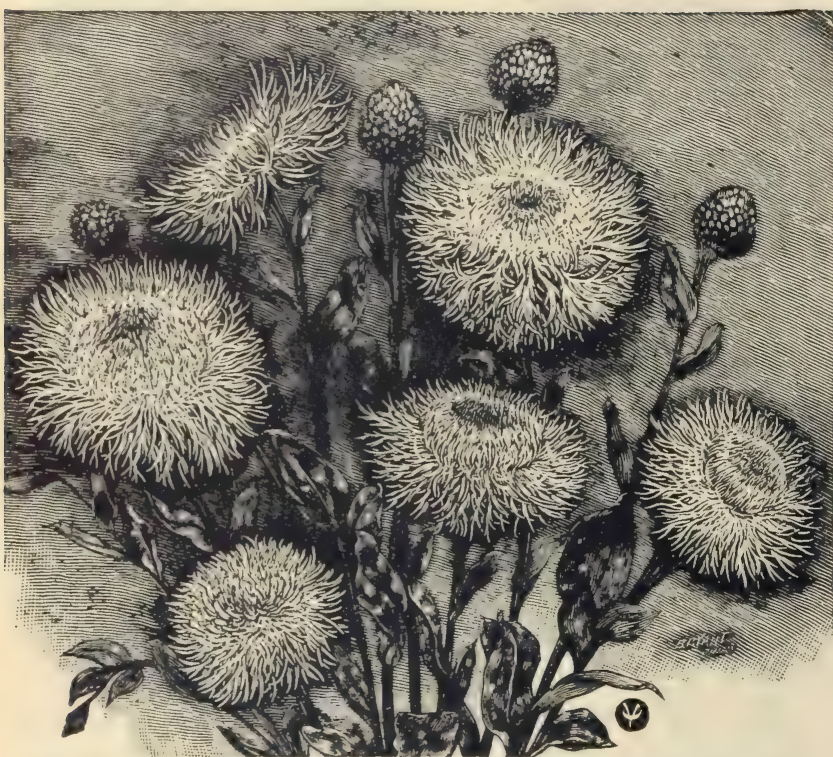

\section{CENTAUREA IMPERIALIS, Americana Alba.}

You should not fail to try this beautiful new Centaurea. It is a hybrid of the Centaurea Moschata (Sweet Sultan), and Centaurea Marguerite, the plants having the vigor of the former and the blossoms, the sweet oder of the latter, al though much larger. A leading Florists' Journal says of it: "It is one of the most important introductions of the present decade. The plant is very vigorous, easy to grow and literally covered with enormous white flowers, fully double the size of Centaurea Marguerite. The stems are long enough to satisfy the most exacting "Belle of New York." It cannot be surpassed for cutting, lasting two or three weeks in water. Easy cultivation and a long duration of bloom make a garden plant unsurpassed by any other annual. Pkt., 5 cts.

Centaurea Imperialis, Mixed. White, Lavender and Yellow. Pkt. 5c

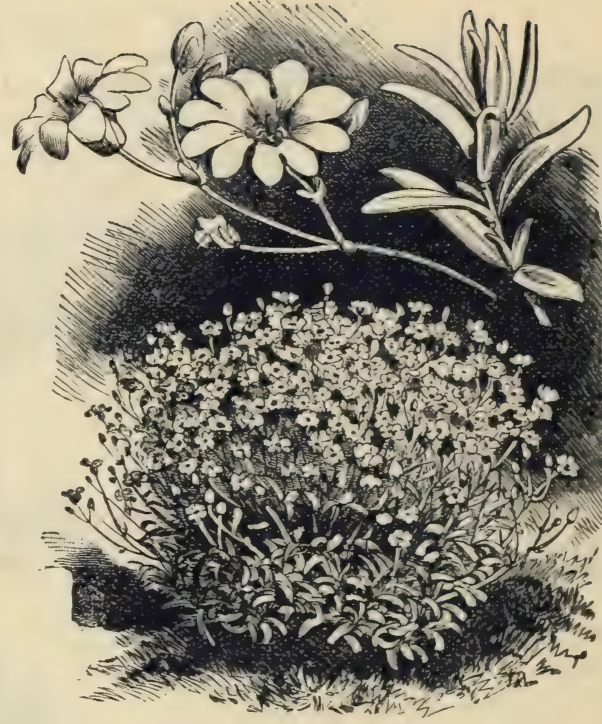

\section{Cerastium Tomentosum}

(Snow in Summer).

A handsome, dwarf foliage plant, with silvery white, variegated leaves, used largely as an edging plant. It is very effective as a border for a coleus bed, or when massed by itself, and is especially appropriate for cemetery use. Flowers white. Hardy perennial. Pkt., 4 cts.

\section{Centaurea Marguerite.}

On account of its beauty and fragrance this Centaurea has established itself in popular favor, and it will not be displaced by its more imposing sister, Americana Alba. Flowers pure white and size of large carnations. Pkt. 5c. 


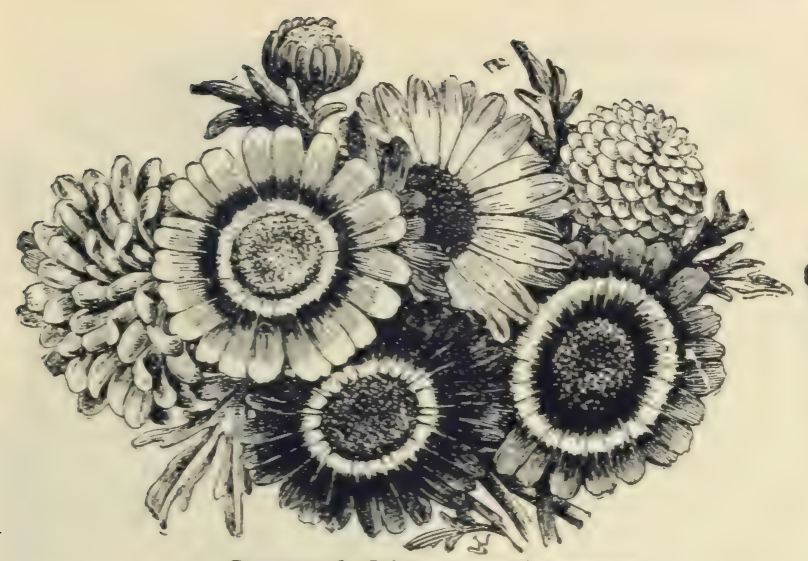

Annual Chrysanthemum.

"French Vargmerites" or "Painted Ladies." These come in both single and doubleforms. The double varieties are button-shaped. densely double, and golden yellow or eream white in color, and are very pretty. The single varieties are pure white. yollow or crimson. with dark centers or zones. Mixed. single and double. Pkt., 3 ets., 2 pkts, 5 cts.

\section{Japanese Chrysanthemum.}

This is the name givento the purenninl or hollse varintivs. These are generally wbrained as plants from florists. but beautiful and often new varieties may be got from seed. Mixed; sared from choice varieties. Pkt., 7 cts.

\section{Maximum Chrysanthemum.}

A splendid hardy perennial, something like the "Marguerite Daiss," only the blossoms are larger. Petals pure white with yellow disk. Pkt., 3 cts.

\section{Ostrich Plume Cockscomb.}

A fringed cockscomb of great beantr. The plant grows two or three feet high and is corrred with immense spikes of gorguns crimson-not the stiff and un graceful blossoms of the older varieties, but with dronping feathery sprays of brilliant color. It was one of the most showr things in my" garden. "Pkt.. 4c. Glasgow Prize cockscomb. The finest dwarf variety, with immense showy dark crimson combs. Pkt., 5 cts.

New Japan Cockscumb. Prramidal in shape, each branch bearing a finely fluted, rich, velvety crimson comb. Pkt., 4 cts.

cockscomb, mixed. The above three varieties mixed. Pkt.. 4 cts.

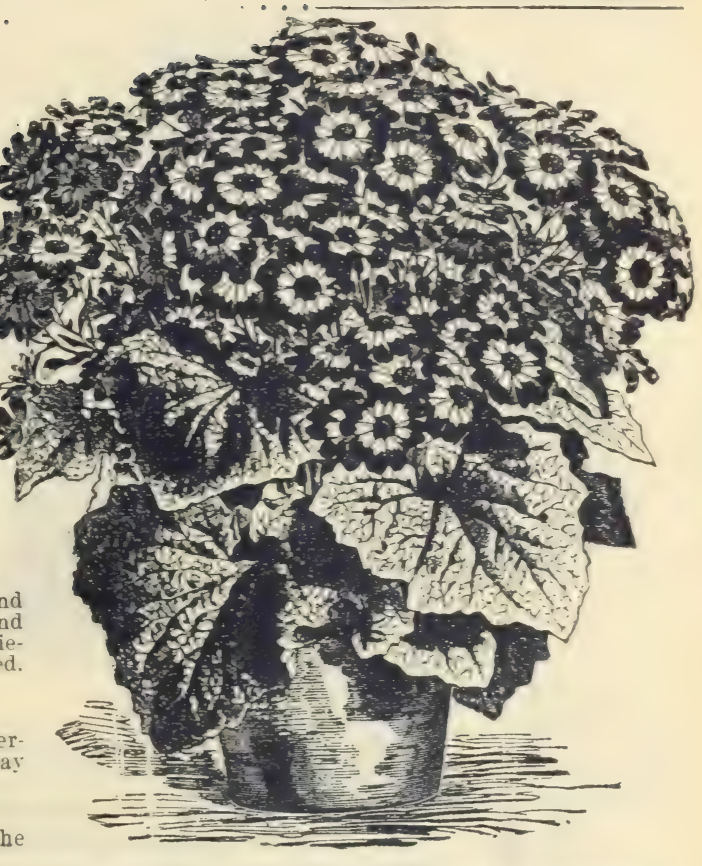

\section{New Dwarf Grandiflora cineraria.}

A beautiful greenhouse plant easily raised from seed. affording a great mass of blossoms in the late winter and spring. The new dwarf rarieties bear much larger flowers, which cover the plants with their brilliant crimson, magenta, violet, purple or variegated shades. Mixed. Pkt., 8 cts.

Cineraria Hybrida. Choice varieties mixed. Pkt., 5 cts. 


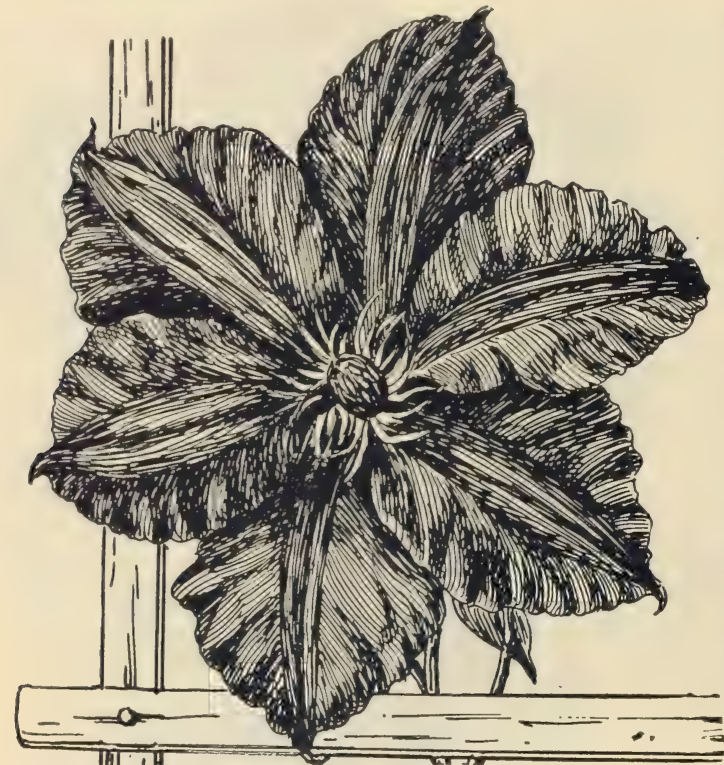

If elematis, Jackman's Hybrids.

These are the large flowering varieties, so beautiful and showy be cause of the dense mass of their immense blossoms, four or six inches in diameter, appearing in shades of blue, white, purple, etc. Fine for trellises, arbors, trunks of old trees, porches, etc. Pkt., 8 cts.

\section{Clematis Paniculata.}

This variety, the Japanese Virgin's Bower, is prized by many more than the largeflowering (lematis. The vine has beautiful dark green foliage, ornamental in itself without blossoms, but during the blooming season it is covered with a mass of feathery white flowers, deliciously fragrant, resembling somewhat the orange blossom. Hardy perennial. Pkt., 5 cts.
Cobea Scandens.

A beautiful climber conservatory window. Nothing is better for ions northern reg. climber. It crows 20 to 30 feet high, and ering a large surface. The foliage is highly ornamental. The bell. chaped flowers open a tear green, turning aflilac blue. Pkt., 4 ets.

\section{Summer eypress.}

A beautiful decorative plant, sometimes PIANT" also "P OF CHICA al quickly, form compact oval bushes, 2 to 4 feet high. The foliage turns in late summer to a brilliant dark red, making a gorgeous display. Splendid or a hedge. Annual.

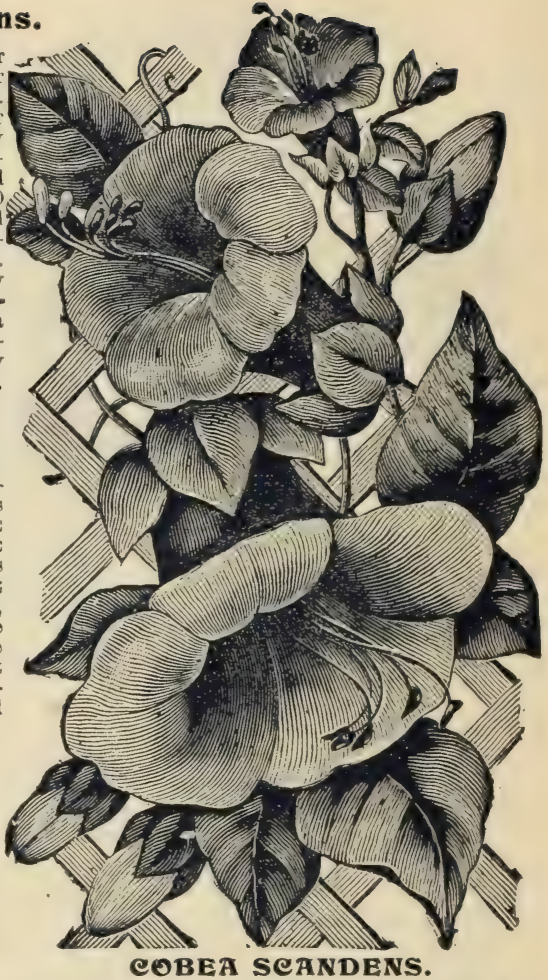

Hampton, N. H., June, 1900.-"I think every seed of my Cobea Scandens came, and my Heliotrope and Centaureas ar
fine."
Mrs. Gro. O. Wieor. fine. 


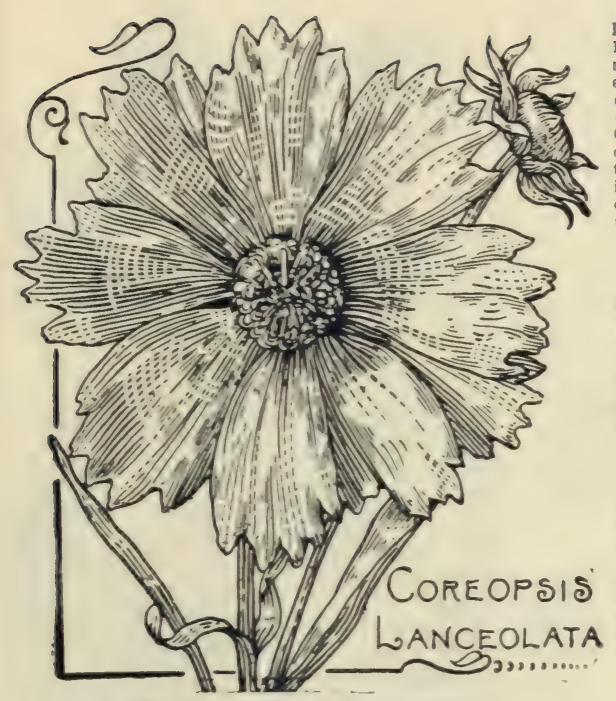

Coreopsis Lanceolata.

A new hardy perennial variety, a wonderful addition to the perennial bed. The blossoms are like great golden buttercups, some saucer-shaped, others flat, the petale having pinked or irregularly fringed edges. Pkt., 3 cts

\section{Coreopsis, Tall Mixed.}

To garden is complete without this old-fashioned flow er, with its wealth of colors in yellow, orange and reddish bronze. Splendid for cutting, either for the house or church decoration. Annual. Mixed. Pkt., 3 cts.; 2 pkts., 5 ets.

\section{"KIondyke"' Cosmos.}

A distinct strain, a dwarf Yellow Cosmos of Mexican origin, bearing beautiful orange flowers. If started in February, it commences to bloom early and will grow and bloom until frost, bearing hundreds of beautiful large golden flowers. Pkt., 4 cts.
Greensburg. Ind.. Mareh. 1900.- "I was ed and pleased ed and pleased on receiring a copy of your er saw any thing so bleas ingly and so up. J. F Hunter.

Ruanoke,Ill. March. 1900.I have receiv19 new cat alogs this spring, and you are the first one I have Mrs. Hent Bucher.

Grand Rapids, Ilich. Jan., 1900.- - . was quite tak en with your pretty Catalog and pleased that our women are coming to the front." Wrs. D.

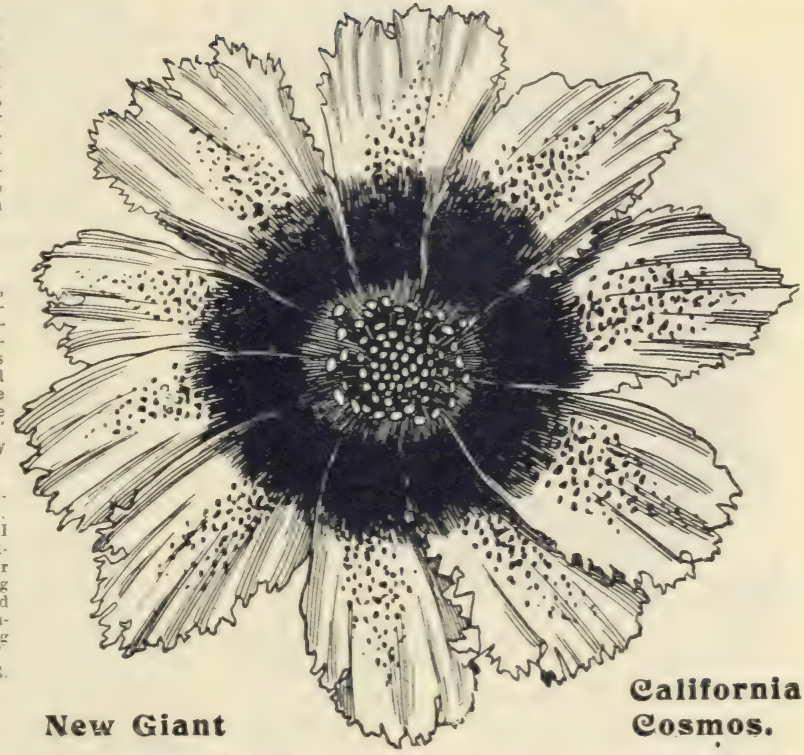

One who has raised the Cosmos will never be without it. The large, bushy plants. 3 to 6 feet higher, are fall with beautiful ray flowers, pink. white or red. Both thowers and foliage are unsurpassed for decoration. This is an improved strain gromn by a (alifornia specialist. It in cludes all the kinds named below, and other fancy varieties. Mixed. Pkt.

4 cts.; 2 pkts., 7 cts.

Giant Pink, Red and White Cosmos, separate, each per pkt.. 4 c. Marguerite cosmos. White. pink and flushed shades. Pkt.. 4 cts.

"Tints of Dawn" Cosmos. White ground, delicately tlecked. Pkt., 4 c.

\section{Early Flowering Cosmos.}

splendid for the more Yorthern states especially, where the frosts often eatch the cosmos before flowering. If you have been disappointed in the othe varieties, trythis. This mixture contains the "Early Dawn" a beautiful white ('osmos, together with the usual cosmos shades. Mixed. Pkt., 4c; 2 pkts, 7 e. 


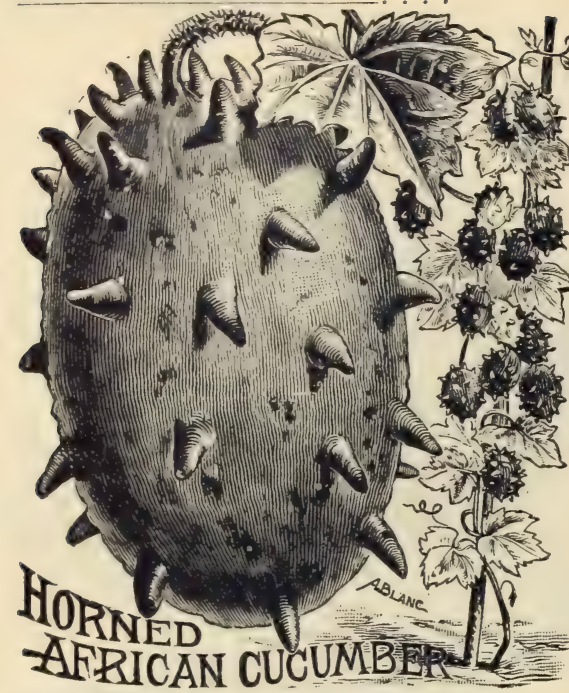

African Horned Cucumber.

The name indicates something for the vegetable rather than the ornamental garden, but this really combines the two, for the vtne is handsome and luxuriant, and the fruit may be used for pickles or eaten green. It is especially useful for a trellis where a dense shade is desired, as it grows faster and makes more vine than almost any other climber, but it is equally good as a trailer. Whether dotted with its pretty yellow blossoms or bearing its curious fruit it is always ornamental. When mature the fruit is about four inches long by two and one-half in diameter, and is covered at intervals with strong points or horns. As it ripens it turns to a brilliant orange and yellow, with speckled and clonded effects. The vine may be grown as a curiosity, an ornament, a shade, or a useful vegetable. Pkt., 4 cts.

\section{wild Cucumber.}

Though common, this well-known climber has so many favorable qualities easy of cultivation, rapid growing, dense foliage, graceful blossoms, self sowing - that we cannot do without it. For the porch and for covering unsightly heaps of rubbish, old stumps or fences, nothing is prettier, cheaper or more satisfactory. Pkt. 3 cts ; oz., 25 cts.

\section{Cypress Vine.}

A beautiful climber, with delicate feathery foliage, bearing bright, velvety, star-shaped scarlet or white flowers. It is pretty to train over old stumps or rock work. Pkt., 3 cts.; 2 pkts., 5 cts.

Digitalis Monstrosus.

The old-fashioned Foxglove, a popular, hardy perennial. The long flower stalks are covered with hood-like flowers, in shades of purple, white, rose and yellow. Mixed. Pkt., 3 cts.

\section{Dusty Miller.}

A valuable foliage plant, making a fine contrast when massed with darker leaved plants, or preity for edging beds. This is a fine mixture of Centaurea Gymnocarpa and Cineraria Maritima seed, The foliage is silvery gray and deeply cut, and has a white downy covering. Hardy perennial. Pkt., 3 cts., 2 pkts., 5 cts. S? My "Culture of Flowers"... Revised and Enlarged for 1901 .

FREE WITH EVERY ORDER.

Mapleton M N W Mapleton, Minn., Mar., 1900.- "We were mueh pleased with the flowers from your seed. The would not helieve that they came from seed." Gratrude Gaefley.

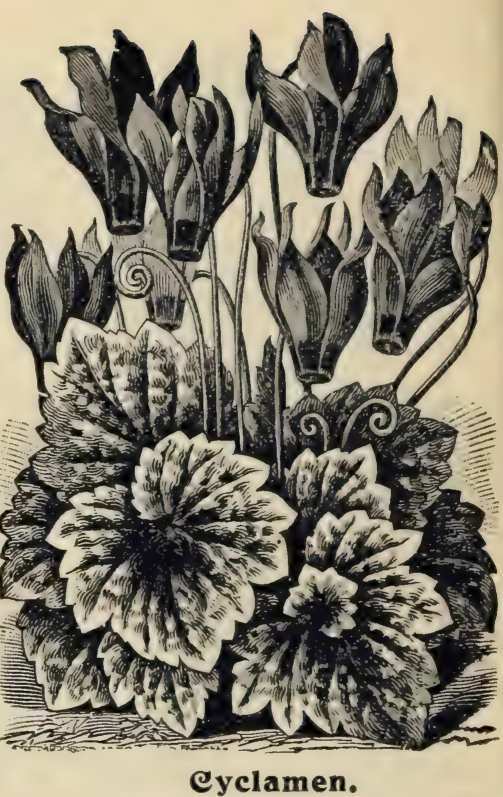

Cyclamen Persicum. Beautiful for its orchid-like blossoms, in pink, white or crimson shades, and ornamental foliage. Seed may be sown at any time, but for winter blooming should be started early in the house or hotbed, as it takes from three to six weeks to germinate. By autumn a bulb will be formed, which will bloom the following winter or spring. Pkt., 5 cts., $\approx$ pkts., 8 cts.

Cyclamen Gigantewm. Very large flowers and highly ornamental foliage.

Pkt., 8 cts., 2 pkts., 14 cts. 


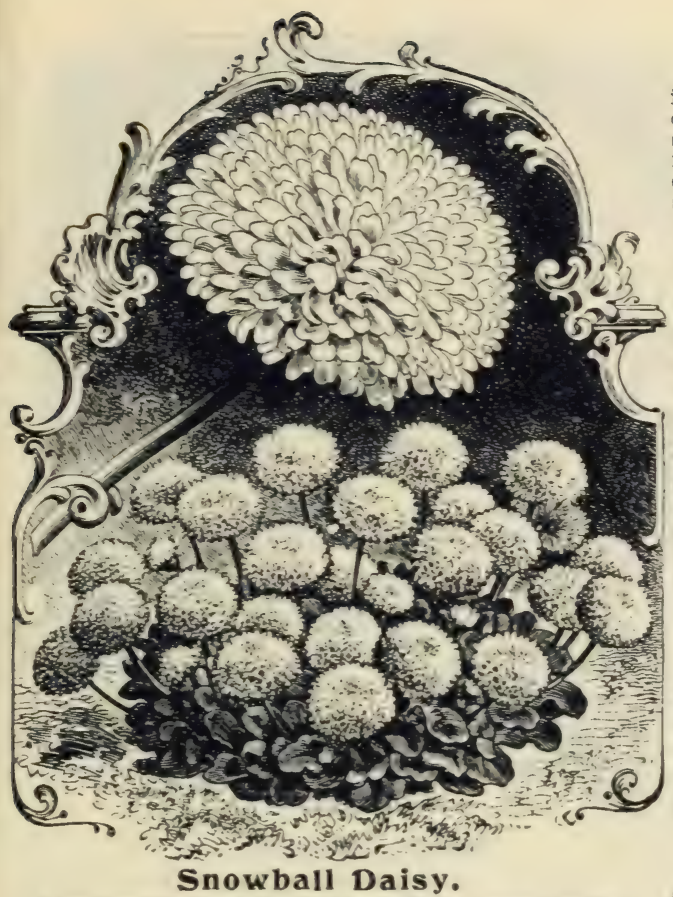

A profuse bloomer, bearing extra large. very double, pure white blossoms, a splendid contrast to its companion in pink. About $\$ 0$ per cent come pure white. Pkt..5c.

\section{Longfellow Daisy.}

The "wee modest crimson-tiplpad" fower. It blooms earls in the spring and is covered during the entire season with it dainty, rosy blossnms. Perennial. blooming the first year if sown early. Pkt.. 4 cts.

\section{Datura.}

A bushy plant, bearing large funnel shaped blossoms, delicately scented, there being as many as 200 blossoms on a single vlant in a season. In the double variety two or three distinct funnels grow one within the other, making a handsome and graceful flower, notwithetanding its large size. My mixture contains the double white, Golden Queen, or double yellow: also the single Datura, called "sweet Nightingale." or "Trumpet Flower, "a soft, velvety white and deliciously fragrant, by many preferred to the double. Pkt., 3 cts.

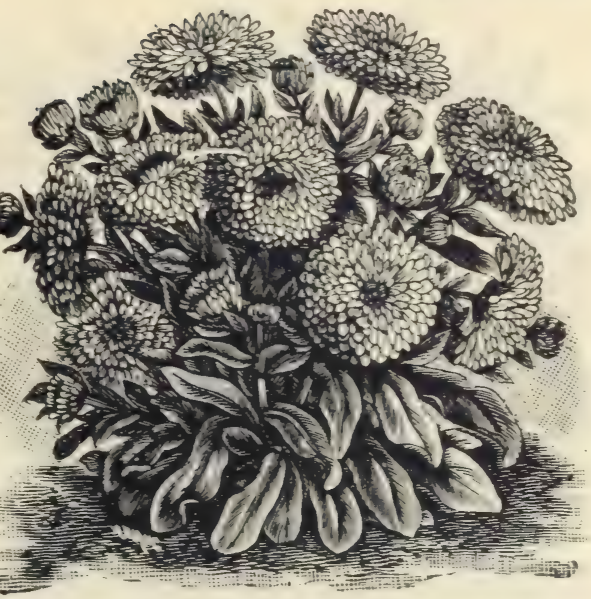

Paris Daisy (Calendula).

Handeome varietiee of the Calendula or "Pot Marigold," one of the finest of rellow flowers for cutting, and considered especially aesthetic for the corsage A ladr. a great lover of flowers, sars: "Your customers once knowing the Paris Daisies would never be without them. They come in every shade of yellow to deep golden, with light centers and with dark, single and double, and it is hard to tell which is the prettier. They are just lovely, and keep so well." Annual. Mixed. containing a large per cent of the two most desirable varieties. Meteor and Orange Prince. Pkt., 3 cts.; $1 / 4-0 z ., 10$ ets.

\section{Orange Daisy (Erigeror Aurantiacus).}

Anv flower fine for cutting is gladly welcomed by all who do much decorating. This somewhat resembles the ister, though the flower heads are much flatter: the flowers are about two inches across and of a bright orange color. Hardy perennial, blcssoming the first season if started early. Pkt.. 4 cts.

\section{Giant Double Daisy (Bellis Perennis).}

To fiower has more often been the theme of the poet than the dainty English Daisy. This mixture will give extra large and verv double flowers and contains also the snowball and Longfellow varieties. I few will come single. Mixed. Pkt., 5 cts. 


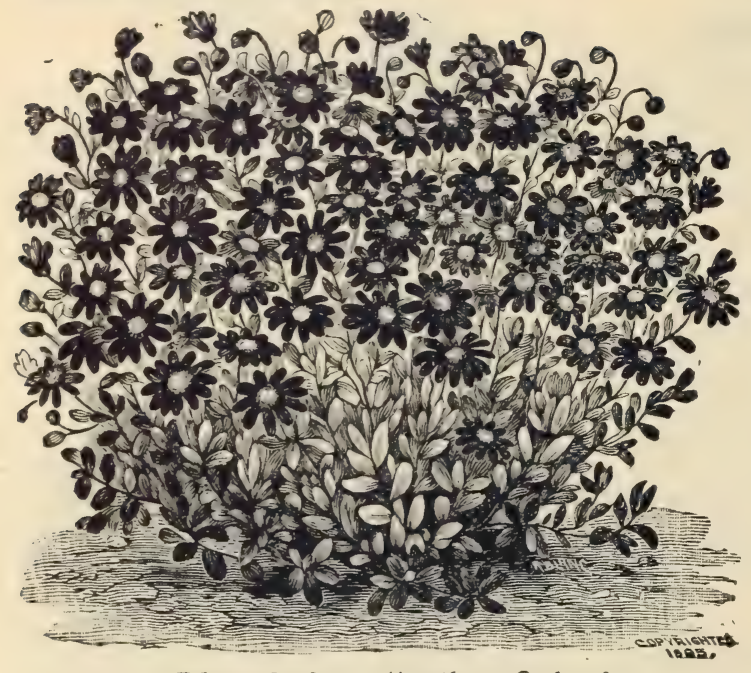

Blue Daisy, (Agathæa Colestis).

The plant grows about eighteen inches high, is much branched and literally covered with blossoms of a beautiful sky blue, a counterpart in size and shape of the Marguerite Daisy. It is a greenhouse perennial and may be used for the garden in summer, or the window in winter. Pkt., 4 cts.

\section{Dracen a Palm, (Dracena Indivisa).}

The Dracena is much used as a decorative plant for vases, window boxes or foliage beds, and it is also pretty for the window. The long, linear-shaped leaves droop in graceful curves, giving somewhat the effect of a palm.

Pkt., 3 ets.

\section{Tom Thumb Dahlia.}

A dwarf single strain of especial beanty and merit. The single sorts are very popular, and by many are considered more aesthetic than the double varieties. Choice mixed. Pkt., 4 cts.

Inkster, N. D., Feb., 1900. - "My neighbors were mach pleased with my Everlastings from yonr seed.

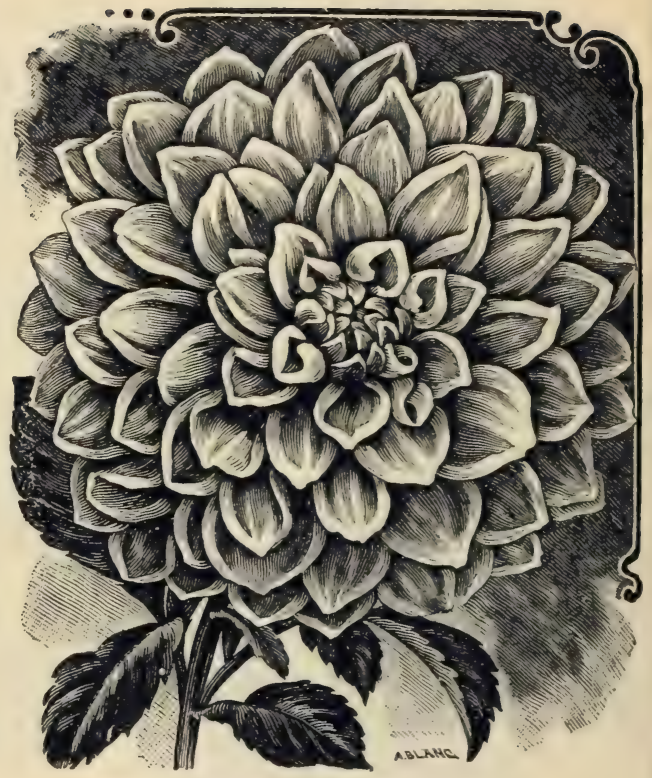

Double Dahlia.

The Dahlia is one of our best autumn flowering plante and is so easily raised from seed that one need not go to the expense of buying bulbs. They flower the first season if started in the house in March or April. To give my patrons several varieties, without increased expense, I have included in this mixture three fine strains, the new Cactus Dahlia, a splendid strain of Giant Dahlias, and the new dwarf sorts. Mixed, many colors. Pkt., 4 cts.

Nampa, Ind., Mar., 1900._"My Dahlias from your seed were fine." Mrs, 0, P. Jorses: 


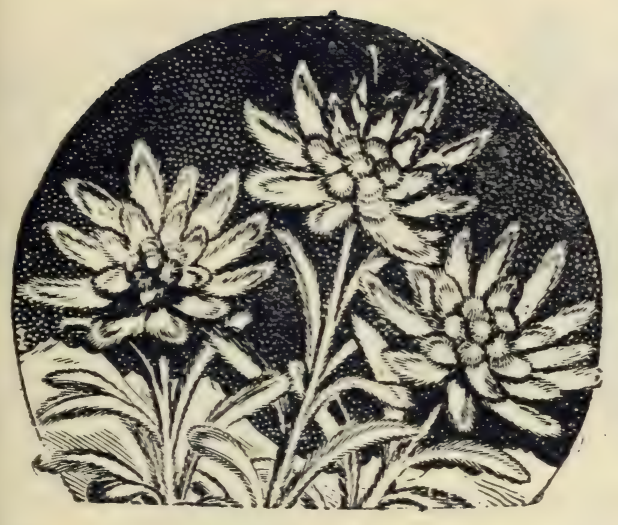

EDELWEISS.

Helichrysum Monstrosum. A popular Everlasting, almost as showy in the garden as an $\mathrm{As}$ ter. Blossoms large and extra double, and in many shades of yellow and scarlet. Mixed. Pkt., 3 cts.

Globe Amaranth. The plants bear great quantities of clover-like blossoms, attractive in bud and flowers. Mixed. Pkt., 3 cts.

Helipterum Sanfordi. Bears large globular clusterrs of bright golden yellow flowers. Pkt., 3 cts.

Rhodanthe. Fine for the garden or pot culture. Flowers deep blood-red, rose and yellow shades, with dark eye. Mixed. Pkt., 4 cts.

Xeranthemum. Showy Everlastings, bearing beautiful violet and rose-colored flowers. Both buds and flowers are handsome to save. Pkt., 4c.

Collection of Everlastings. One packet each of my eight varieties. 20 cis,

\section{Mixed Everlastings.}

A mixture of the above named eight varieties, which will give a large variety both in form and colur or these popular flowers. Pkt., 4 cts.

\section{EVERLASTINGS.}

Acrocinium Roseum. One of the most beautiful Everlastings. Flowers are double their delicate rose pink contrasting with the golden centers. Pkt., 3 cts.

Ammobium Alatum. Flowers white and very double. Being emaller than the Helichrysum or Acroclinium they give variety to the winter bouquet. The buds, too, are very pretty and should be gathered freely. Pkt., 3 cts.

Edelweiss. The Alpine flower of which so much is written in song and story. Pkt., 5 cts.
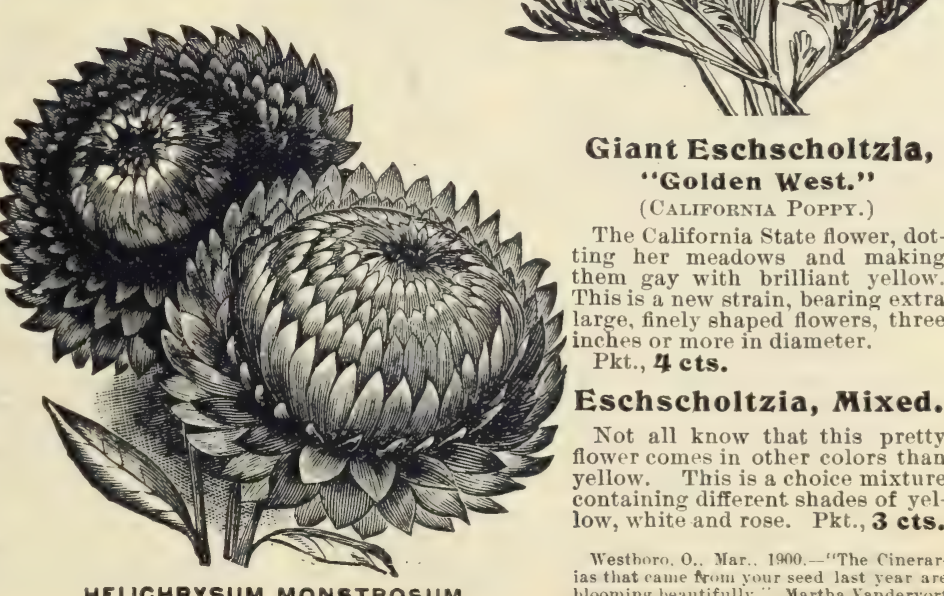

Giant Eschscholtzla, "Golden West." (California Poppy.)

The California State flower, dotting her meadows and making them gay with brilliant yellow: This is a new strain, bearing extra large, finely shaped flowers, three inches or more in diameter. Pkt., 4 cts.

Eschscholtzia, Mixed.

Not all know that this pretty flower comes in other colors than yellow. This is a choice mixture containing different shades of yellow, white and rose. Pkt., 3 cts.

HELICHAYSUM MONSTROSUM
Westhoro, 0.. Mar.. 1900.--"The Cinerarias that eame from your seed last year are blooming beatifully." Martha Vandervort 


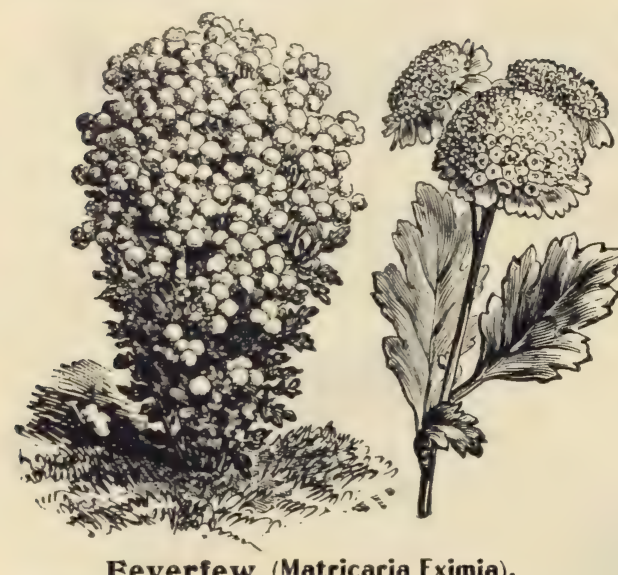

Feverfew (Matricaria Eximia).

Snowball. The plants grow about eight inches high, oval in shape, and are very desirable for bedding or for edging. During the long blooming season they are densely covered with clusters of pure white, double fiowers. Pkt., 3 ets.

Golden Ball. Another dwarf variety, bearing beautiful golden ball-like flowers. A combination of the white and golden Matricarias makes a lovely show, either in mass or as an edging. Both are hardy perennials, blooming the first season. Pkt., 3 cts.

Golden Feather. Parthenifolium Aureum. Low growing plants, with golden variegated foliage, extensiveIy used for edgings. A beautiful contrast with the darker foliage plants. Pkt., 3 cts.; 2 pkts., 5 cts.

\section{Sweet Fern.}

A graceful plant, growing four or five feet tall with finely cut foliage and tiny greenish flowers, prized for its aromatic qualities. A few sprays aftord a beautiful garnish for a bouquet, or placed in the handkerchief box impart a delicate perfume. Hardy annual. Pkt, 3 ets.

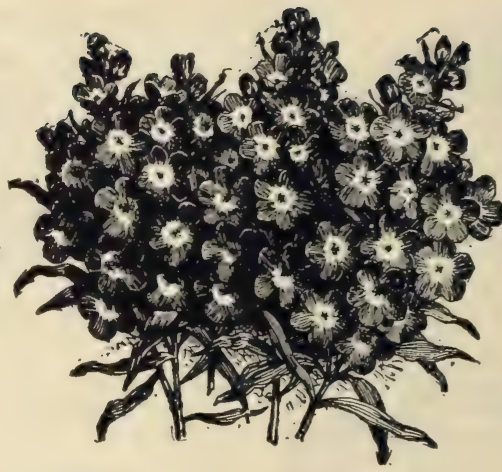

Euphorbia.

A mixture of $\mathbf{E} \mathbf{u} \mathbf{p} \mathbf{h} \mathbf{o} \mathbf{r} \mathbf{b}$ i Heterophylla, the "Mexicen Fire Plant," and Euphorbi Variegata, "Snow on th Mountain." Both are remarkabl for their showy foliage. The leave in the former turn to a brillian orange scarlet, and those of th latter are prettily veined with white, so that the tips of th branches look like immensw clusters of white blossoms. Pkt., 3 ets.

\section{Scarlet Flax (Linum).}

A showy annual, bearing durin long season, hundreds of bril iant scarlet flowers. Foliage an flowers equally pretty. Pkt., $3 c$

\section{Forget $=$ Me $=$ Not (Myosotis).}

In days of old, a German knight lost his life in trying to secure for his lady-love a tiny blue flower, growing on the Danube, crying, as he fell inte the river, "Vergiss mein nicht!" (Forget me not), thus naming this beautiful flower, and making it an emblem of tidelity. The variety here offered is of compact habit and a profuse bloomer, presenting when in full flower a mass of exquisite blue. Hardy perennial. Pkt., 4 cts.; 2 pkts.. $7 \mathrm{c}$.

\section{Freesia.}

These beautiful bulbous plants ma be easily raised from seed, and made to bloom the flrst year. Sow at any time in pots or boxes, in light, rich soil. Perennial. Splendid strain of white and mixed colors. Pkt., 5 cts.

Spencer, Ida., Feb., 1900._"Your seed were seeds this year. My Fuchsias, Bahy Rose and Carnations grew nicely and are now beautiful spencer, Ida., Feb, 80 good that we send to you for most of our
Lynchbarg, Va., Mar., 1900._- "Your seed were so entirely satisfactory last year the I wish to try them again."

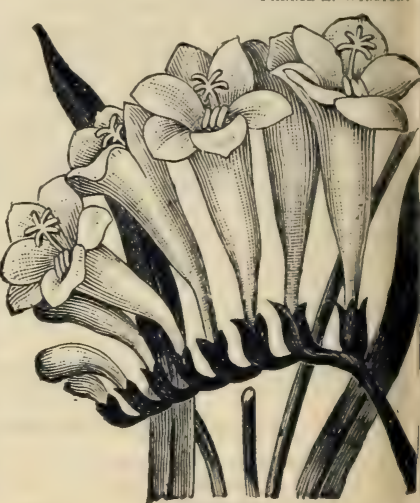

FREESIA. 


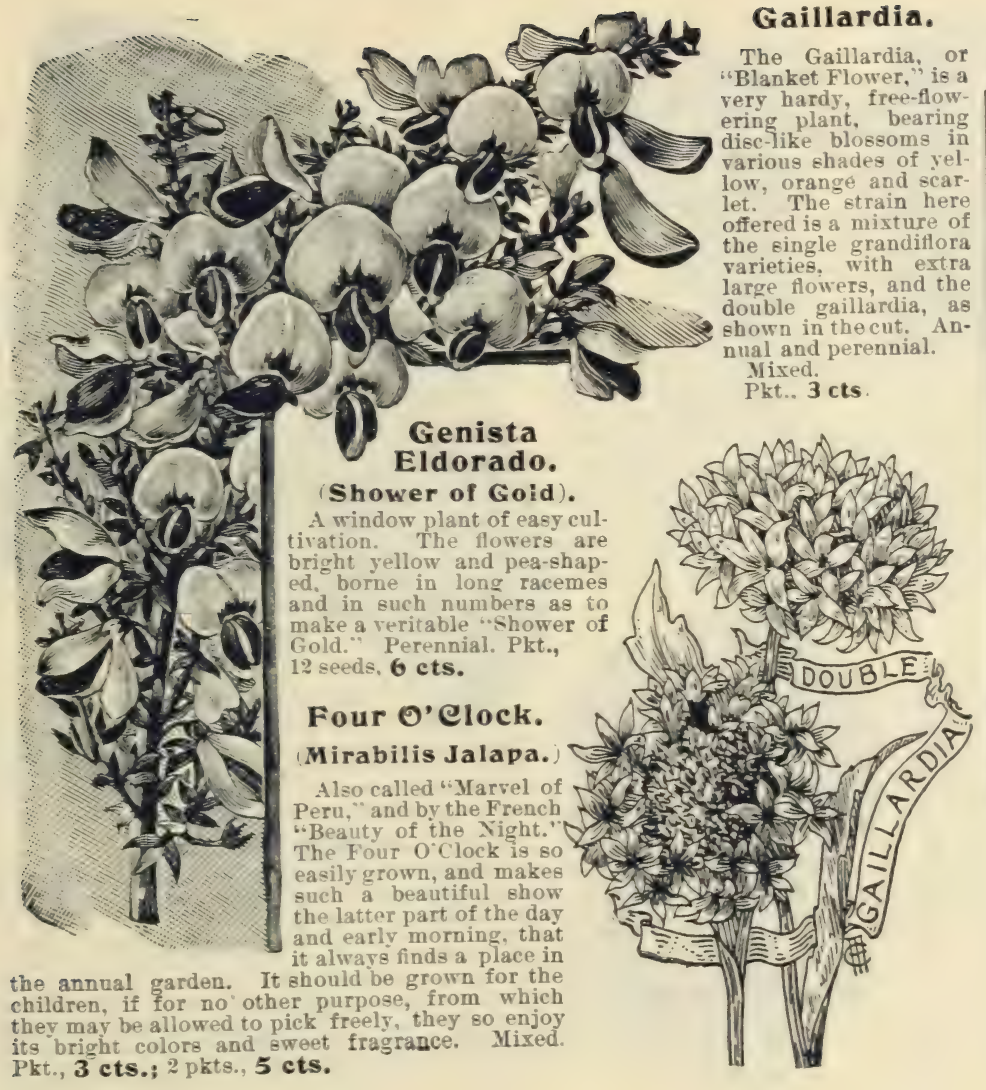

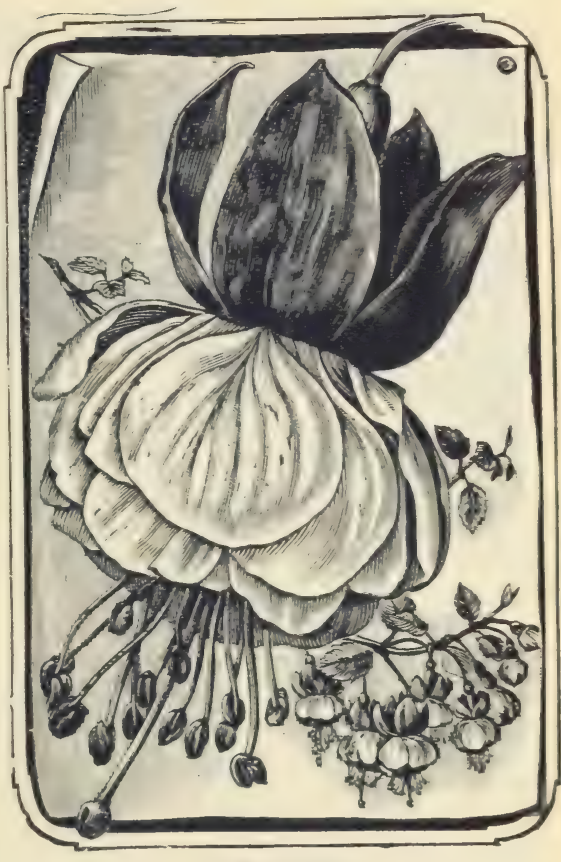

Fuchsia.

Seedling Fuchsias make robust plants and often give new varieties. If sown in the early part of the year they will be in flower in July or August. This seed has been carefully saved from choic single and double varieties. Pkt., 25 seeds, 8 c.

Scotland, S. D.. Mar.. 1900.- - Your seeds are the best I erer
tried. The Daisies are heauties: Balsams, Forget-Me-Nots and Four O'Clecks were all very nice." Mararert GisBos. 


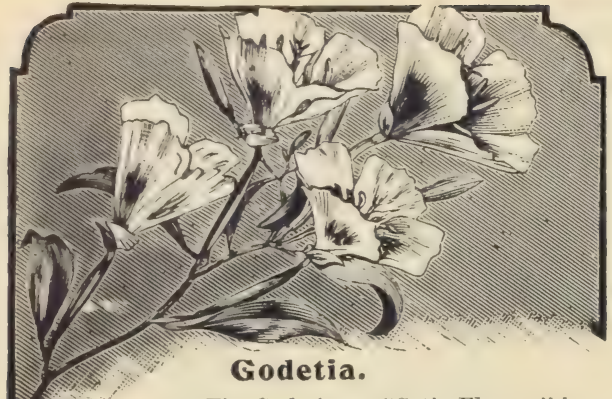

The Godetia, or "Satin Flower," is a low growing annual, bearing large, wideopen, shining, satiny flowers of white. lilac rose and deep shades of pink and crimson delicately shaded and spotted. They bloom in such abundance as almost to hide the foliage, and when massed together make a brilliant show and are especially adapted for an edging plant. They will thrive even in shady places where nothing else grows. Mixed. Pkt., 3c.

\section{New California Geranium.}

Seedling Geraniums almost always give some new varieties, and being easy to cultivate they are an interesting plant to grow from seed. This mixture contain 8 splendid new strain of California Zonale varieties in shades of blush, pink, crimson, scarlet, also many beautiful varieties of the Sou de Miranda and Aureole types, together with strains of Lady Washington and AppleScented Geraniums. Knowing that only the best gives the best satisfaction, I have discarded this year the cheaper grade of Geranium at a low price, but offer instead a half packet of $m y$ choicest strain, the only difference being that the latter does not contain the applescented variety.

New California Geranium, best mixed. 40 seeds, 10 cts.

New California Geranium.

Ilalf packet, 20 seeds, 5 cts.

ApplesScented Geranium. The finest plante come only from seed. Pkt., 30 seeds, 6 cts.

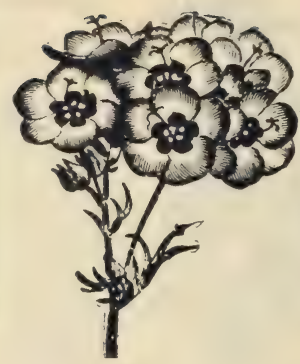

Gilia.

The Gilia grows about a foot high, has graceful, finely-cut foliage, serving nicely for a decoration of green, and dainty flowers in rose, blue or white. It is suitable for rockwork and desirable for cutting Pkt., 3 cts.

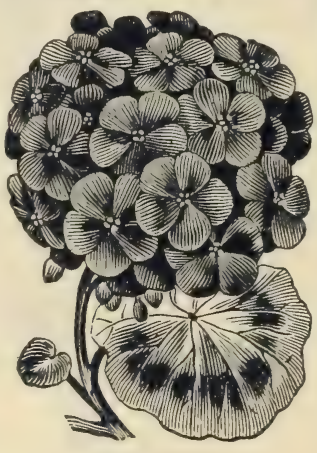

GERANIUM.

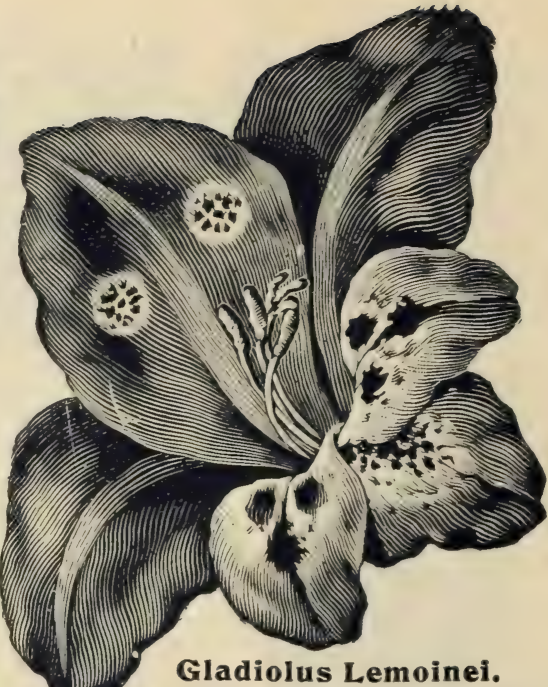

It is interesting to raise Gladioli from seed and see the endless variety of colors and fantastic markings that come from the seedlings, scarcely any two being alike. No finer varieties are offered than the Lemoinei. Pkt., 4c.

\section{Hardy Hibiscus.}

The Marsh Mallow; hardy perennial that bloome first year, beginning in midsummer after flower ing season for most of the shrubby perennials is over. My seed is a mixture of three choice varieties, namely: "Crimson Eye," having large white blossoms with a bright crimson center: "Sunset," flowers canary yellow with garnet throat; and "Royal Pink," soft delicate pink, with throats of a deep crimson. The blossoms are hollyhockshaped, measuring from six to eight inches across; are very abundant and showy. Pkt. 5c. 


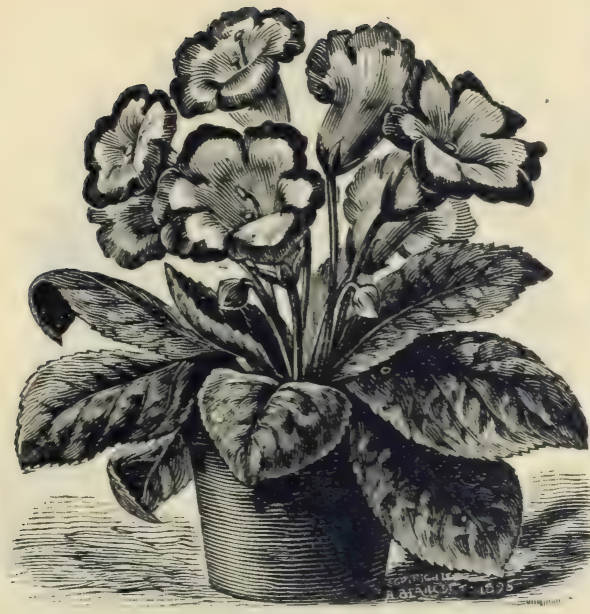

Gloxinia Grandiflora.

Popular greenhouse and conservatory plants of dwarf habit and profuse flowering. The handsome, bell-shaped flowers, are of gorgeously brilliant colors, curiously spotted and mottled, ranging from darkest, richest shades of crimson, all through different shades of red to pure white, and some appear in blue, making as showy a plant as one can have in the window. I can hardy imagine anything more beautiful than well-grown plants of Gloxinia-except more of them. I offer the choicest mixture of French Hybrids of the Grandiflora type. Pkt., 75 seeds, 7 c.

\section{Lavatera.}

Old fashioned annuals that deserve to be restored to more general favor. The blossoms are large and cup-shaped, pure white or delicate pink. If the foliage is plucked out and blossoms massed, they are fine for the vase or corsage. Pkt., 3 cts.

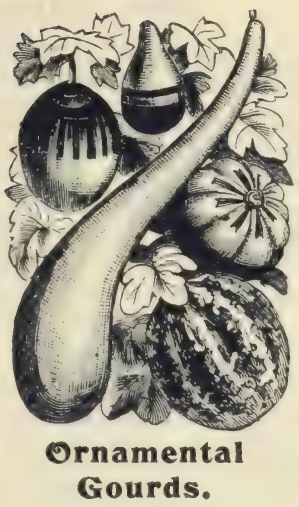

If you have an odd corner or an old brush heap, trail the gourd vine over it. Its fruit has many uses, but if for no other purpose raise it for the little ones. They much enjoy the gaily striped, odd shaped fruits. This mixture will be sure to please, as it is made up of many named varieties, including dipper, striped, pear-shaped, ostrich egg, apple, orange, turban, or Japanese Red, and dishcloth gourds. It will give both large and small sizes and an innum erable variety of shapes. Mixed. Pkt., 4 cts.

Madison, Wis., Apr., 1900._"I was visiting my son of New Lis bon, and must say that their flowors from your seed were the most beautiful I have ever seen, especially the Asters. Mrs, S, H. Cowles.

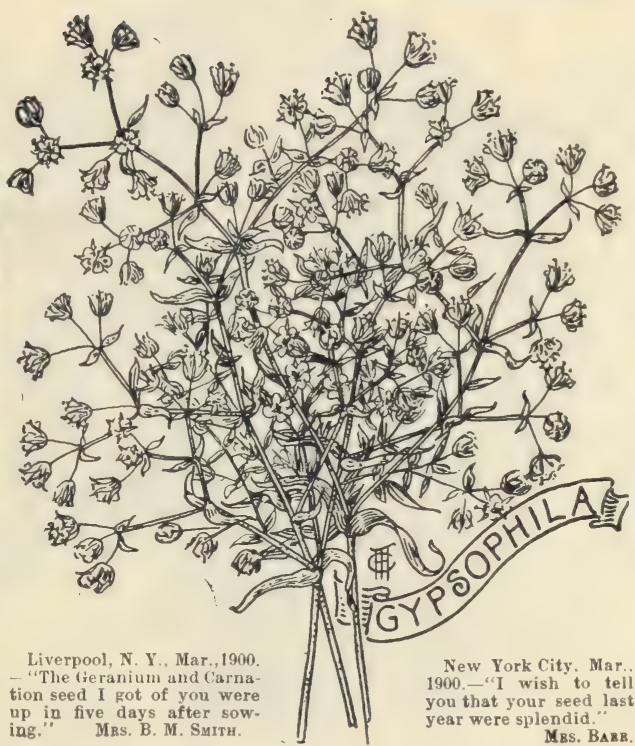

\section{Gypsophila Paniculata.
"Angel's Breath."}

No lady who delights to adorn her rooms with beautiful flowers should be without the Gypsophila. It is extensively used by all who do any decorating to mix with other and coarser flowers. Its mist-like sprays set off a bouquet as dainty lace does a lady's dress. Hardy perennial; once established, you will always have it

Pkt., 3 cts.

Gypsophila Muralis.

The annual variety. Sow a quantity to use for decorat ing. Pkt., 3 cts. 


\section{MISS EMMA V. WHITE,}

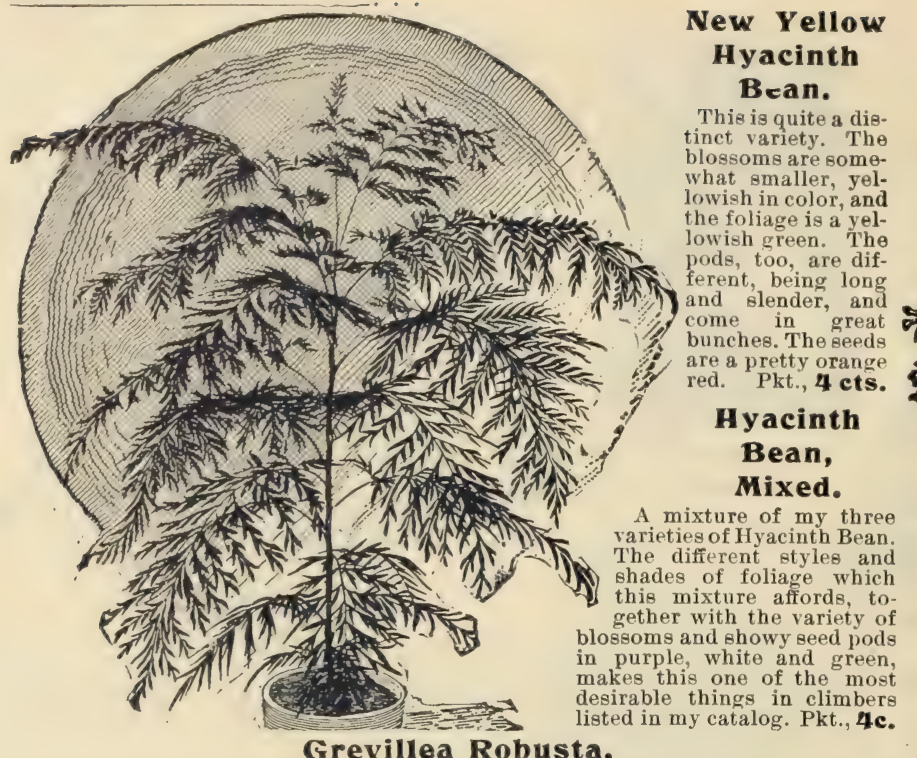

Grevillea Robusta.

The "Silk Oak," a valuable decorative plant, germinating readily from seed and making in two or three months' time a very ornamental little plant. The laciniated foliage gives it somewhat the appearance of a fern, but it is much hardier and more useful as a decorative plant. Pkt., 5 cts.

\section{Hyacinth Bean, (Dolichos Lablab).}

Always a desirable climbling vine, because of its quick growth and dense foliage. The flowers, great clusters of purple, are abundant and pretty, and the large shining, purple seed pods are very showy. Pkt., 3 cts.

\section{New Hyacinth Bean, "Princess Helen."}

One of the prettiest and most rapid climbers, growing by midsummer to a height of 15 feet. There will be an abundance of snow-white, sw set-scented blossoms, very pretty in themselves, but more showy still are the creamy white pods which follow and hang to the vines till late fall. Pkt, 4 ets.

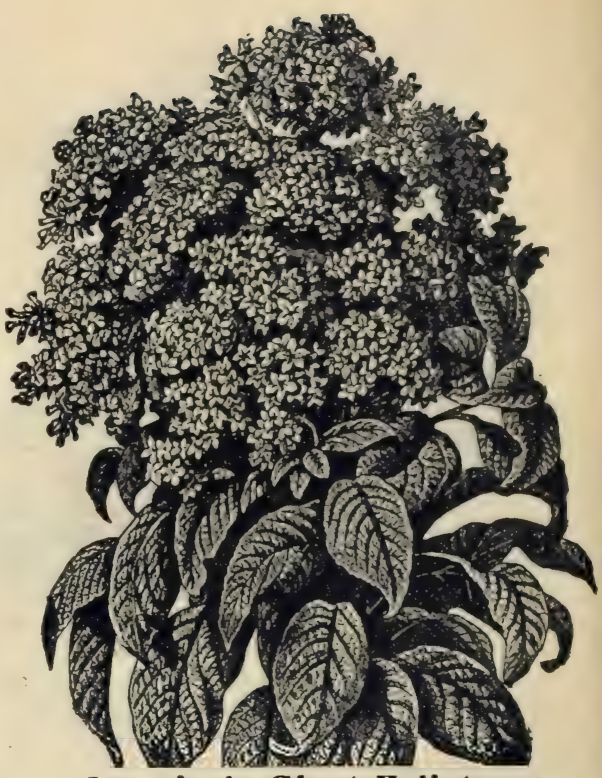

Lemoine's Giant Heliotrope.

A magnificent new strain, with large, glossy leaves and immense heads of deliciously fragrant flowers, much larger than in the ordinary varieties. A single truss in a well-developed plant measures from ten to fifteen inches across and contains thousands of individual florets. Pkt, 5 cts.

Garden Heliotrope, Valeriana Officinalis.

Hardy perennial, doing well in almost any position. It grows to a height of two feet, and bears large heads of sweetly-scented, delicate flowers. Mixed. red and white. Pkt., 3 cts. 


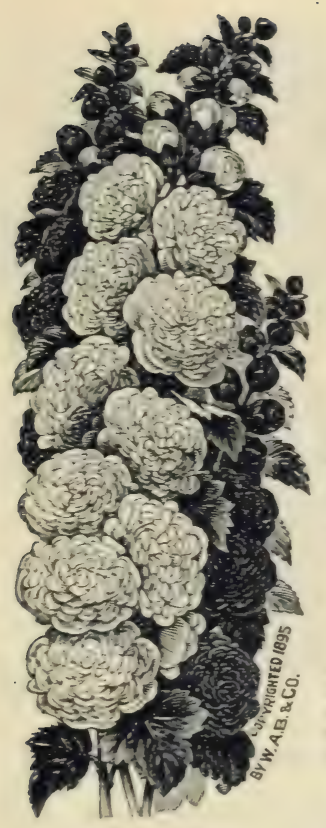

Double

Hollyhock.

A choice strain with magnificent spikes of extremely double flowers. Mixed. Pkt., 4 cts.; $1 / 4-02,25$ c. Double Pink, Pkt., 4c. Double Red, Pkt., 4c. Double White, Pkt.,4c. Double Yellow, Pkt.tc

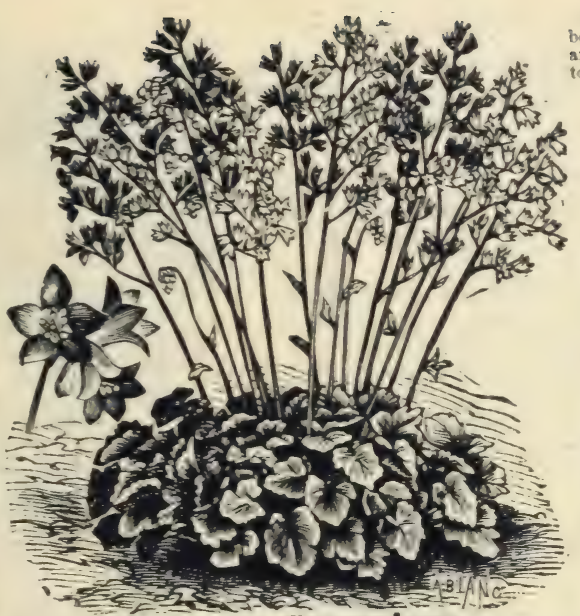

Heuchera Sanguinea.

One of the finest of recently introduced hardy perenniale. The plants are dwarf and compact. with foliace beautifully cut and marbled. The flowers are a brilliant red, very showy, and borne in extravagant abundance in long. graceful spikes. It should find a place in every garden, Pkt., 4 cts.

Fringed Hollyhock-New Allegheny.

A handsome new type lately introduced. The A handsome new ty pe latedy with petals somewower irregularly arranged and finely eut, and of a than transpare flower. instead of the stiff and bunchy apgraceful floter. indinary double blossom. The flowpearance of the ordinary double blossom. The

Pkt., 4 ets.

Single Hollyhock.

The single Holl hocks are fully as ghowy and handThe as the double varieties, and make a nice back ground for the gaaden fence or perennial bed.

Pkt. 2 ets. ${ }^{1 / 4}$ oz.. 10 ets.

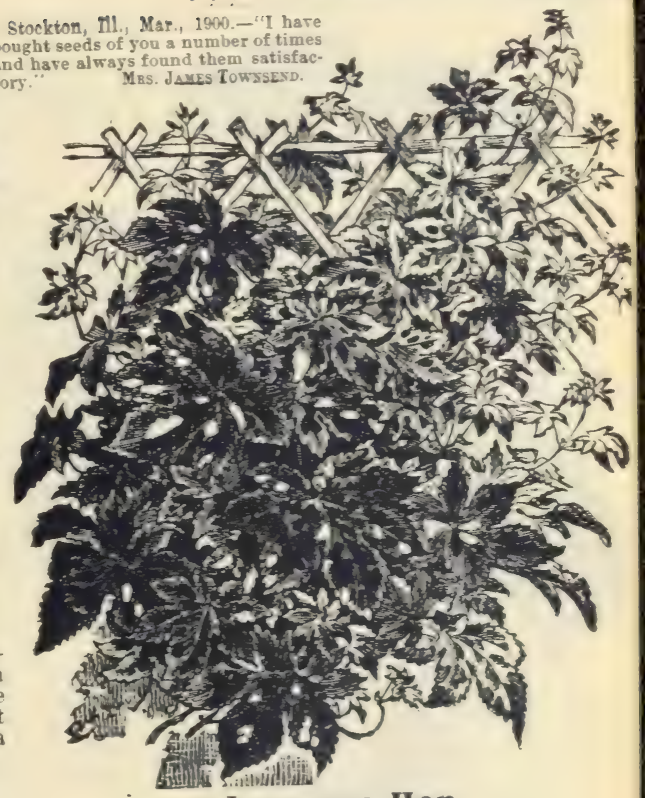

Japanese Hop.

For any place where a rapid growing rine is neede For any place where a the Japan Hop. The foliage luxuriant, the leaves being smaller and more delica than those of the common hop, and euriously mark with silvery and yellowish-white streaks. Hardy pe ennial. Pkt., 4 ets.

\section{Japanese Iris}

(Iris Kaempferi).

All know the beauty of the Iris family. The Kaem feri begins flowering in. July and continues for fire or ? weeks, the blooms rivaling the lily in stateliness and t 


\section{Lychnis Chalcedonica.}

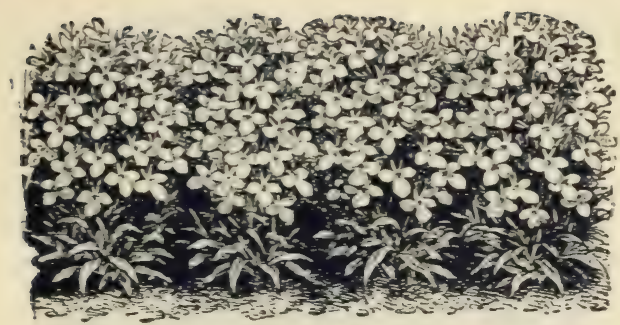

Every list of desirable perennials contains the Lychnis. It blooms the first year, and if kept from seeding will be covered for months with its brilliant scarlet flowers. It is the most striking and notice able thing in the garden. Pkt.. 3 cts.

\section{Lavender.}

The old-fashioned, sweet-scented Lavender, al ways found in our grandmother's gardens. One sees now-a-days dainty farors made by using the leaves, or by weaving the long stems with "baby" ribbon into pretty wands for the handkerchief box. Pkt., $\mathbf{3}$ c.

Lobelia, Crystal Palace.

To plant is finer for edgings or for massing in a bed: very effective also for the hanging basket rockerv, porch bos, or it makes charming little pots of blue to fill in the niches in the conserrs tory window. It blooms in four or five weeks after sowing. The handsomest blue variety.

Pkt., 3 cts.; 2 pkts., 5 cts.

Lobelia, "The Parrot."

A charming new red, white and blue Lobelia The flowers are dark blue, with whit eyes and carmine red spots. Pkt., $\mathbf{5}$ cts.

\section{Double Larkspur.}

Double varieties, much branched and as handsome as the Gilliflower. The spikes are sometimes a foot in length. closely crowded with the dainty double flowers, in many shades. Those who have seen only the old-fashioned single varieties can bave no idea of their beaut

Mixed. Pkt., 3 cts.; 2 pkts., 5 cts.

\section{Perennial Larkspur.}

Stocky plants, with immense spikes, densely crowded with large flowers in rich blues and other shades. The Bee Larkspur, included in this mixture, is interesting because of the curious way

the petals are folded up in the center of the flower so as to resemblo a bee. Very hardy. Some will blossom the first year. Mired. Pkt., 4 cts.

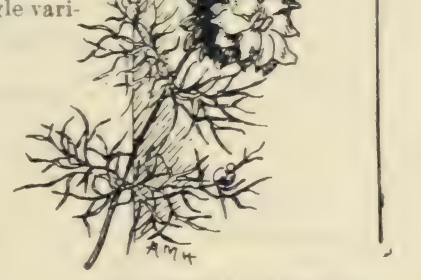

DOUBLE LARKSPUR.

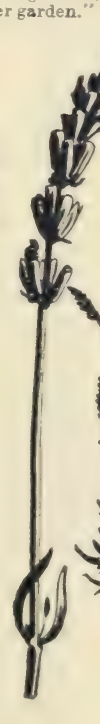<smiles>C1C[As]1</smiles>
$+(m)=120$

Norwalk, Ct. Apr., 1900. "I bought seed of you last year and al
were good. I had a lovely flower garden."
MrS. H. KxAPp.

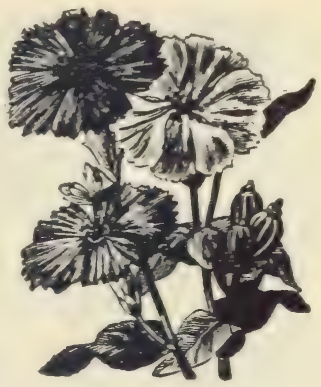

LYCHNIS.

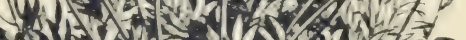

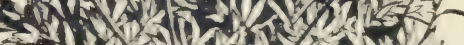

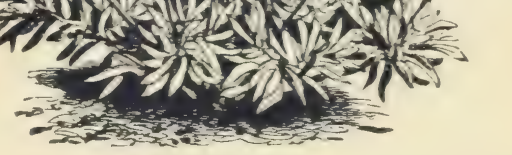

LAVENDER. 


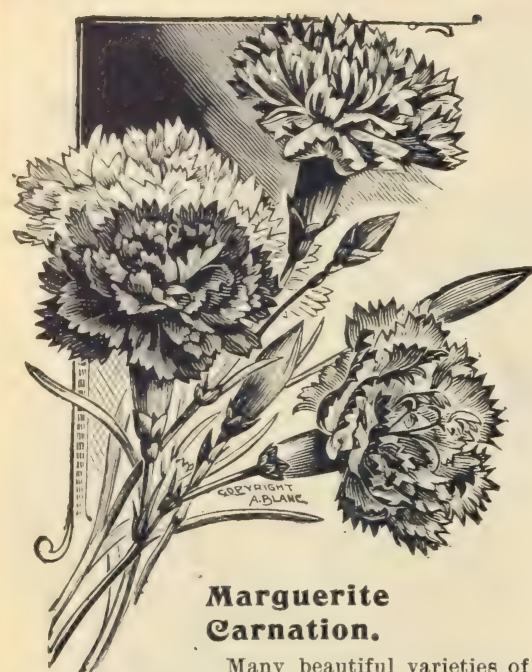
Carnations may be obtained from seed, equaling the greenhouse-grown blooms in fulness and fragrance. These new favorites are a great advance over the old varieties, as they will be in blossom in from two to four months from seed sown in the open ground. If taken up and cut back they make tine plants for the window in winter, or seed may be sown at any time in pots for indoor blooming. Fully eighty per cent will come double. Choice mixed. Pkt., 5 cts.

\section{Giant Marguerite Carnation.}

A new, large flowering, wonderfully improved strain. The blossoms are very double, with petals beautifully fringed, and under proper cultivation will often measure three inches across. Mixed, including the new yellow carnation.

Pkt., 8 cts.

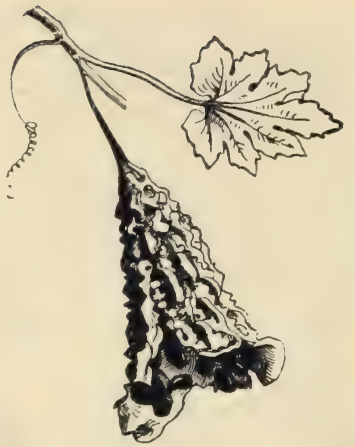

\section{Mormordica}

Charantia,

"Balsam Pear,"

An ornamental climber of the Gourd family. It makes a rapid growth and affords a splendid dense shade. The foliage and flower are both very pretty and it is a great curiosity to see hanging from the vines the long pear-shaped fruits, in various tints of delicate green, from the tiny newly formed, to full grown orange yellow, covered with warty excrescenses, but most curious of all is its habit of bursting open, showing the seeds, clinging to the walls, each incased in a brilliant crimson jacket.

Pkt., 4 cts.

Marguerite Carnation. Flaked yellow. Pkt., 6 cts. Marguerite carnation. Rose. Pkt., 6 cts.

Marquerite Carnation. White, Pkt., 6 cts.

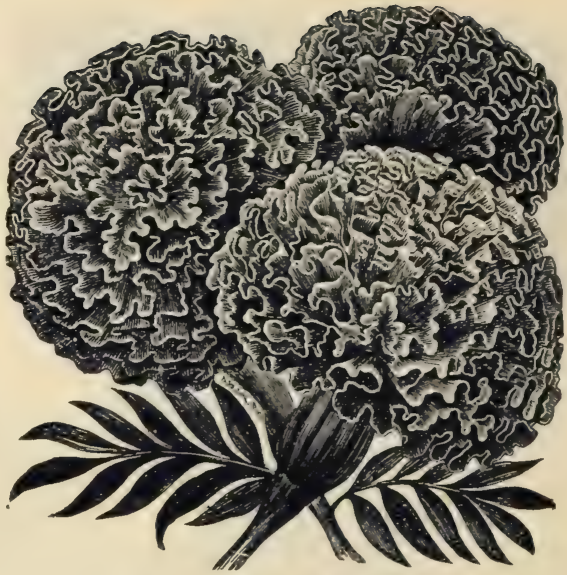

Eldorado Marigold.

The Eldorado grows very rank and tall and is sur mounted by great golden balls, sometimes fourteen inches in circumference. As many as flfty or sixty blossoms have been counted on a single plant at one time. The flowers are very double, with petals quilled as in the Dahlia, appearing in shades of lemon, golden or orange yellow. It is by far the handsomest of all the Marigolds. Pkt., 3 cts., 2 pkts., 5 cts.

\section{Dwarf French Marigold.}

Those who object to the Marigold because it is coarse and straggling will find in the dwarf varieties compact and ornamental plants. The miniature blossoms, too, in various shades of yellow and bronze, make a brilliant show in the garden. Children enjoy them because they are so easy to grow. Mixed, including Legion of Honor, Pulchra and many other choice double and single varieties, Pkt., 3 cts, , 2 pkts., 5 cts. 


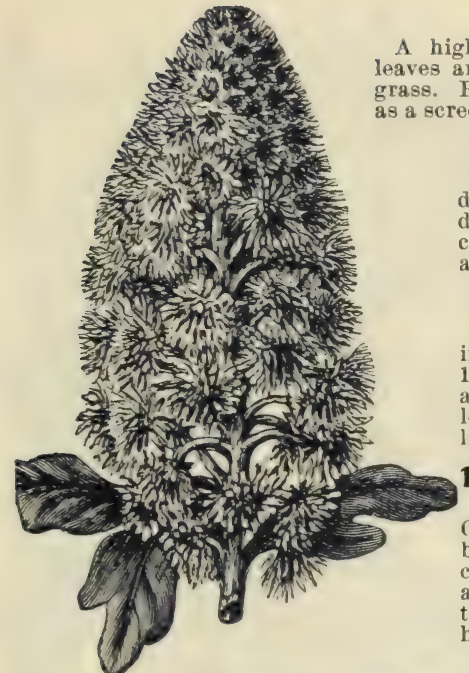

Japanese Maize.

A highly decorative ornamental corn. The Aves are variegated, like those of the striped rass. Pretty for the center of a tropical bed, or a screen against a fence. Pkt., 4 cts.

\section{Maurandya.}

A graceful annual climber for the window or open ground. The leaves are of a dainty green, pretty shaped, and for decorative purposes it is almost as desirable as Smilax. Pkt., 3 ets.

\section{Mina Lobata.}

A rapid and luxuriant climber, attain ing a height af 15 to 20 feet. The flowers, 15 to 20 in a cluster, appear in the bud as a bright red, then change to orange yellow, while the blossoms are a still lighter tint. Annual. Pkt., 4 cts.

\section{Brazilian Morning Glory}

A unique variety of the Morning Glory family. It is a rapid grower, bears large clusters of beautiful rosecolored flowers, and is very ornamental, because of the tiny brown spines that cover branches and stems and the hairy appearance of the leaves. Pkt., 5 cts,

\section{Allen's Defiance Mignonette.}

The finest and most fragrant variety yet produced. The spikes are very long and the individual florets large, and have such long keeping qualities as to make it the favorite for cutting. Pkt., 4 cts.

\section{Giant Pyramidal Mignonette.}

The spikes are large, pyramidal in shape, and of a reddish tint. Pkt., 3 cts. $1 \mathrm{oz}, 15 \mathrm{cts}$.

\section{Golden Machet Mignonette.}

A dintinct new variety of the well-known Yachet type, but the massive spikes, instead of having the reddish tinge, are crowded with golden yellow flowers of delicious fragrance. Pkt, 4 cts.; one-half ounce. 20 cts.

\section{Mignonette, Odorata.}

The common sweet variety. Pkt., 2 cts.; oz., 10 cts.

Mixed Mignonette. A mixture of my four named varieties. Pkt., 3 cts.; 2 pkts.. 5 ets.

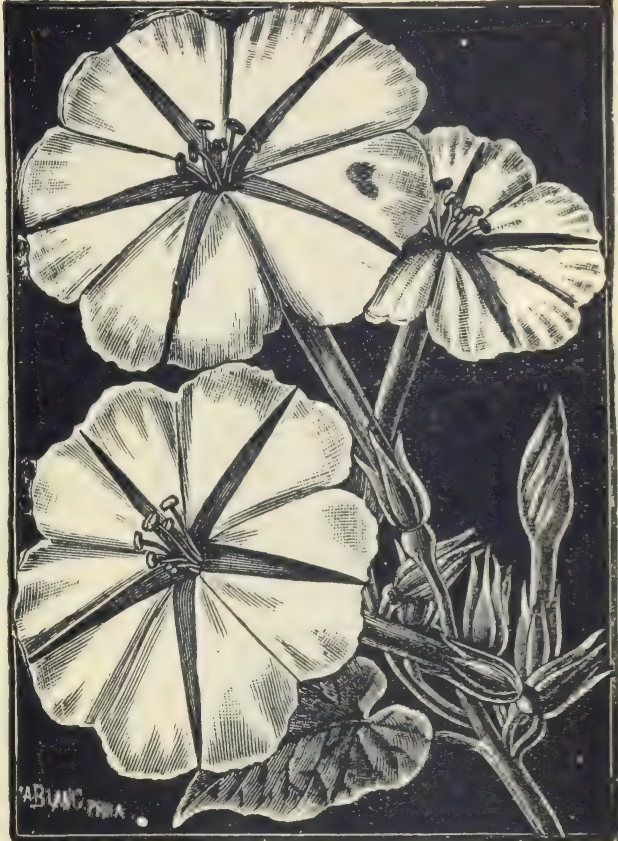

Early Moonflower (Ipomoea Granditlora).

The genuine Southern Moonflower, of whose beauty and fragrance so much is told. People in the North are often disappointed in not getting the Moonflower to bloom before frosts. Here is a grand new hybrid variety from 40 to 60 days earlier than the old style, bearing just as large and beautiful flowers. It will come into flower in the extreme north about Aug. 15 from seed sown out of doors May 1. Starting it in the house in April will give a longer period of bloom. Pkt., 8 seeds. 7 ets. 


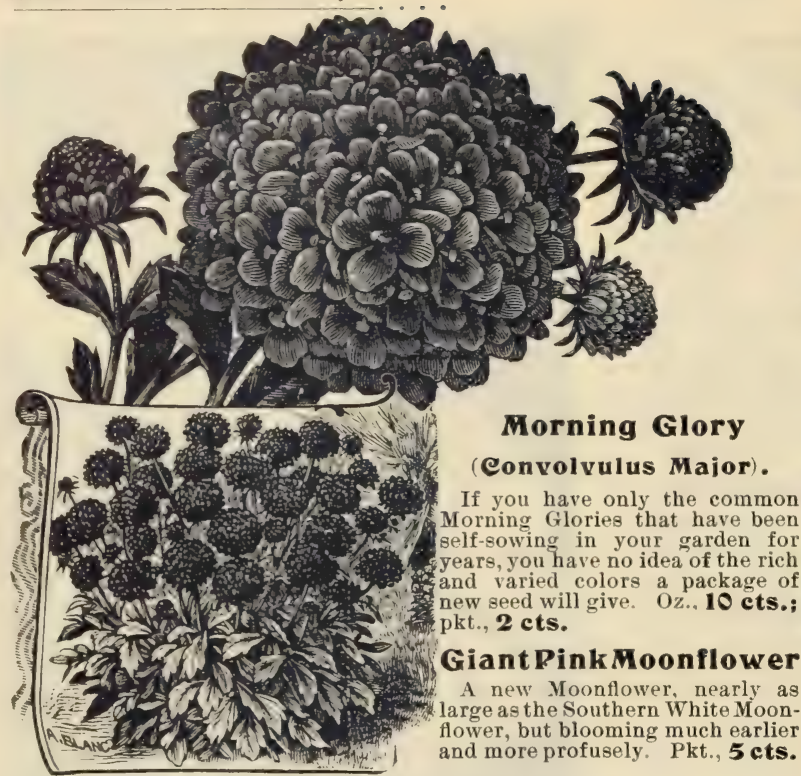

Mourning Bride, Giant Black.

A new Scabiosa, a rich velvety maroon, of extreme size, so Jark as to be almost black in color. Pkl., 4 cts.

\section{Mourning Bride, Snowball.}

A white Sicabiosa, a vivid contrast to its companion in black, Large and very double. Pkt, 4 cts.

\section{Mourning Bride, Mixed.} (Scabiosa).

A mixture of many colors, ranging from white through lilacs and reds to a dark purple maroon. The flowers are borne on long etiff stems and are fine for cutting. Mixed. Pkt, 4 ets.

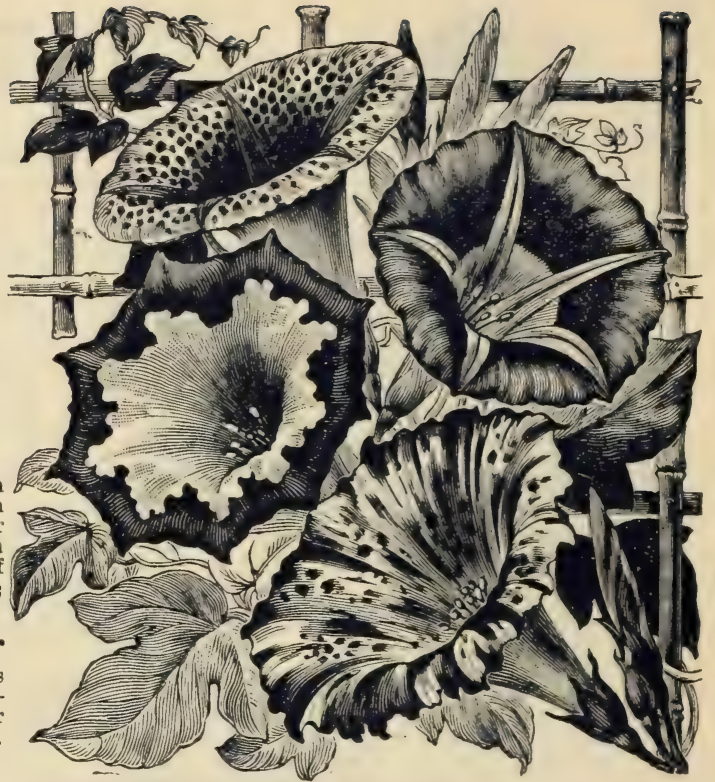

Imperial Japanese Morning Glory.

The beautiful, rich, velvety colorings of the common Morning Glory are intensified in this variety, and the shadings and markings are decidedly curious and varied, while the size of the flowers, 4 and 6 inches across, and variegated foilage are additional elements of beauty. This has proved a great delight, and all that the brilliantly colored designs and extravagant descriptions depict. See my "Culture of Flowers" for special directions. Mixed. Pkt., 4 cts.; 2 pkts., 7 ets. Monkey Flower (Mimulus).

Mimulus Tigrinus. Beautifully spotted. Pkt., 3 ets. Mimulus Moschatus (Musk Plant). Yellow. Pkt, 3 cts. 


\section{DWARF NASTURTIUMS.}

Crystal Palace Gem. Sulphur yellow with maroon spots. Pkt., 4 cts.

Golden King. Grand flowers, golden yellow. Pkt., 4 ets.

King Theodore. Dark maroon, with dark foliage. Pkt.. 4 ets.

King of Tom Thumbs. Brilliant scarlet. Pkt., 4 cts.

Tom Thumb, mixed. A splendid mixture of dwarf varieties. Pkt., 4 cts.; oz., 12 cts.; 1/4 lb., 40c.

\section{Liliput Nasturtium.}

A extra dwarf variety, forming emall dease bushes, which is so profuse in flowering as to fairls hide the foliage. Mixed. Pkt., 5 cts.; oz., 15 cts.

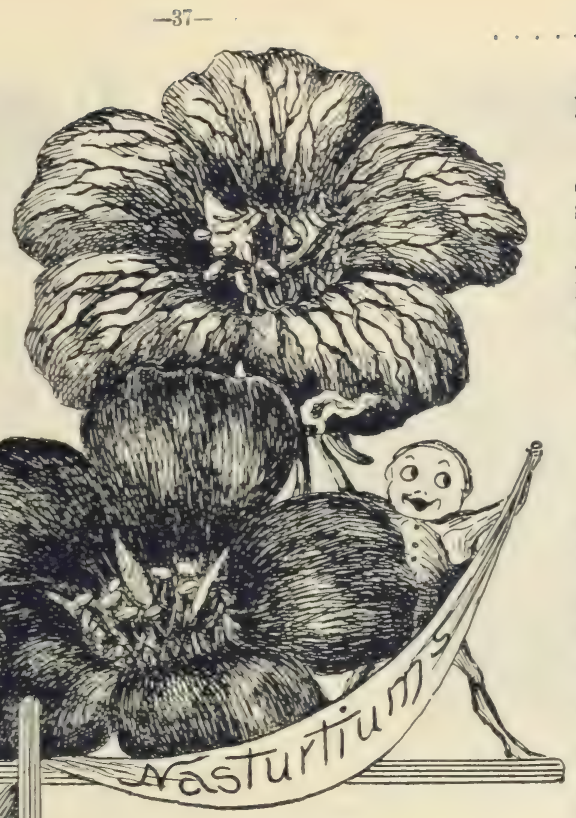

Nasturtiums, Mixed.

An opportunity to try all my varieties of Nasturtiums. This contains the three mixtures described above and my eight named varieties, and includes everything I offer except the Liliput Nasturtium. Pkt., 5 cts., 3 pkts., 10 cts., oz., 20 cts.

\section{Collection of Nasturtiums.}

\section{One packet each of my twelve kinds, 36 cts.}

Peru, Ill., April, 1900. - "This is the third year I have ordered of you. My Asters last year were a perfect success, also the Nasturtiums, and I cannot say enough of the Japanese Morning Glories.

Phillipsburg, N. J., April, 1900.-" This is my second order. Gloxinias:
TALL VARIETIES. Madame Gunther Nasturtium.

Tall, or climbing Nasturtiums, Their robust wich foliage and extra shades. This strain has been before public some years now and an unrivaled Mixed. Pkt., 5 cts.; 0z., 12 cts ; lb., 35 cts.

\section{Lobbianum Nasturtium.} 位oing Nasturtiums, far tall varieties. Many colors mixed. 4 cts.; Oz, 10 cts.; $1 / 4 \mathrm{lb}, 30 \mathrm{c}$ rilliant Fulgens. Vivid, ge. Pkt. 5 cts

King Theodore. A dark Mercier Iaco.

lvety, purplish crimson. Pkt.5c. he handsomest yellow. Foliage, ight green; flowers a rich, golden ellow, borne in great profusion. kt., $5 \mathrm{cts}$. 


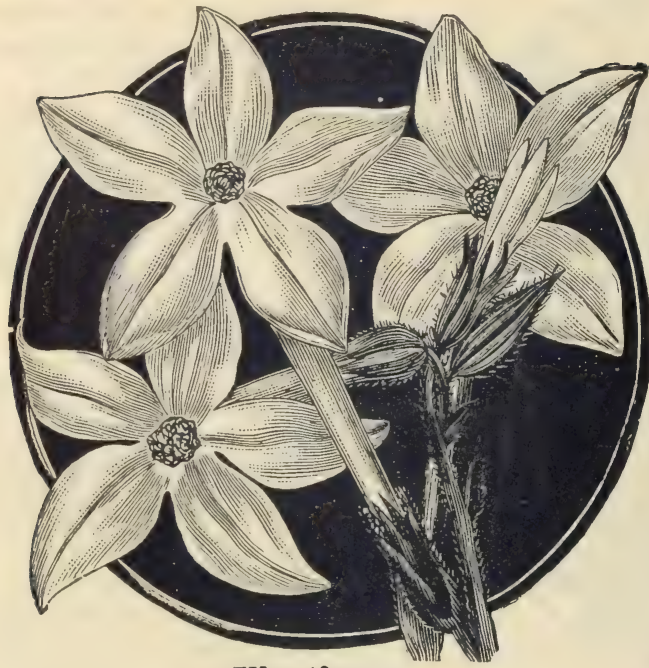

Nicotiana.

A night-blooming tobacco, a lovely flower for the garden or window. The plant attains a height of three feet, and at evening or early morning is covered with large, pure white, star-shaped flowers of delicious fragrance. It can be kept in flower the whole season by cutting back from time to time. Annual. Pkt., 3 ets.

\section{Japanese Tree Paeony.}

The flower queens of China, and in Japan, where viewing the flowers is one of the important fetes of the land, they are great favorites. Their immense blossoms measure from nine to twelve inches across, are very double and of most vivid colors, appearing in white, pink, mottled and scarlet shades. Mixed. Pkt., 10 seeds, 6 cts.

Murdock, Neb., March, 19\%._-"My Asters and Poppies from your seed were the best I ever had.

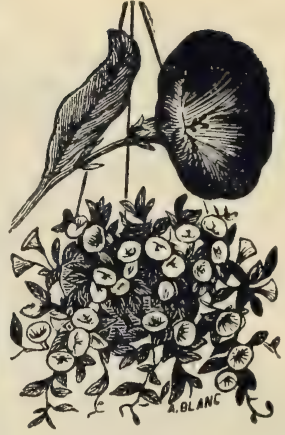

Nolana.

The Nolanas are charming little trailing plants, unsurpassed for pots, rock-work or hanging baskets. Flowers a beautiful sky blue. Pkt.; 3c.

\section{Nemophila.}

Pretty, free-flowering hardy annuals, with cup-shaped flowers of many bright colors. They thrive best in somewhat moist soil and partial shade. For convenience in making change, this is put in at one cent a package. Mixed.

Pkt., 1 et.

\section{Nigella.}

An old-fashioned annual, known also as "Love-in-amisl," "Devil-in-a - B u \& h " "Ragged Lady," etc., from the manner in which its pretty blue flowers are curiously enveloped in a thick,tangly mass of fine feathery foliage.

Pkt., 2 ets.

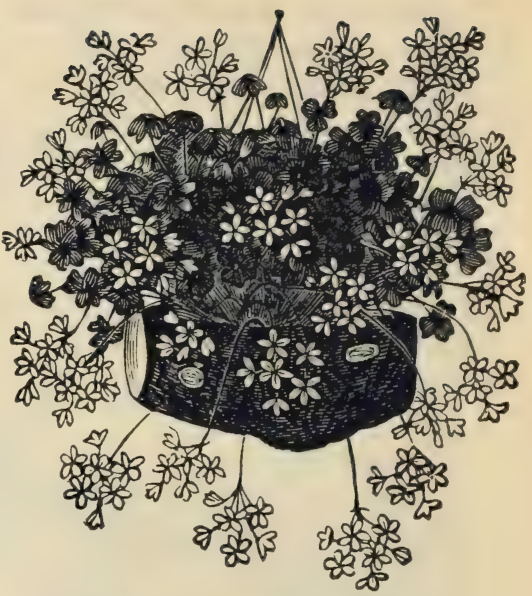

Oxalis Tropacoloides.

An annual variety of Oxalis, bearing a profusion of lovely deep yellow flowers, blossoming from June to September. It is much prized on account of its foliage, the leaves being a rich purplish brown, which makes it so desirable for edgings. It is the variety 80 often appearing in our parks and is as valuable as those grown from bulbs. Pkt., 3c.

\section{Chinese Paony.}

In the varying flower fashions the Prony has been somewhat neglected of late, but the tide has turned, and it is again on the crest of popular favor. It is offered now in many new shades. The Chinese varieties are somewhat later flowering, but furnish the finest forms: easily raised from seed. Once established it will repay the long waiting. Mixed. Pkt., 14 seeds, 5 cts. 


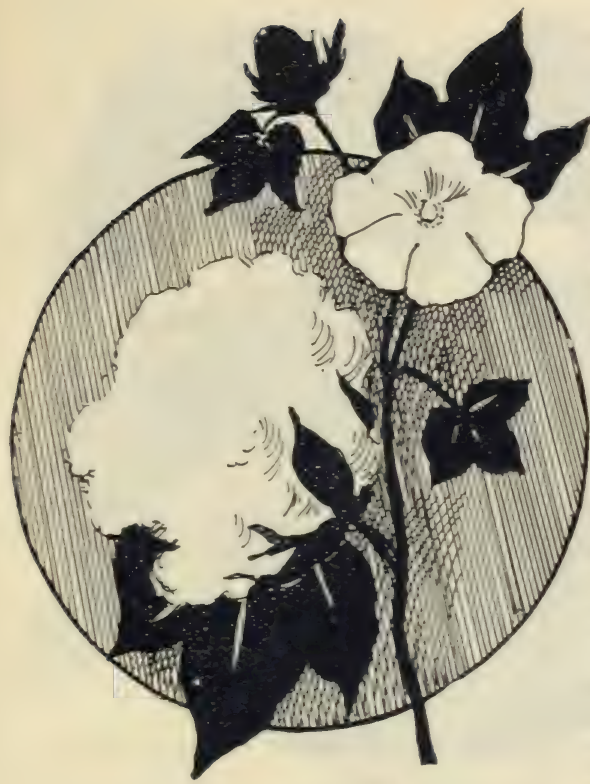

Ornamental Cotton.

Something new and choice for the foliage bed. In habit it is like the common cotton of the south, which is indeed a lovely plant. The ieares, stem and stock are a deep glowing red. like a dark coleus. The Howers are sompthing like those of a Hibiscus and on opening in the morning are creamy white, streaked and dashed on the outside with pink: toward noon they change to a deep pink. and at sundown are red. The unripe bolls are also red, but when ripe they burst and outstreams the snowiest white cotton lint. This makes a wonderful show massed in a bed, or is handsome as single speci menis, Pkt., 5 cts.; 2 pkts., 8 cts. Tail, Pampas,

Pkt., 5 cts.
Oenothera Mexicana

"Mexican Primrose."

If you want something that will slways be in flower, $t r y$ the Mexican Primrose, as it is t is pretty for a hanging asket or as a pot plant, or it rows equally well and blooms as profusely in the open The blossoms are ped. of a pretty rose

OrnamentalGrasses

These should have as permanent a place in the garden ornamenting the border. for summer cutting, and for the inter bouquet to mix with indispensable, This ture is made from 14 named vrieties, including Quakin Animated Oat and other choice and desirable grasses.

Prairie City, Mo., March, 1900. "Was well pleased with your vegetable seeds." Helen Fox.

\section{Phacelia Campanularia.}

A low growing annual, as pretty for pots, or for edgings, as the Lobelia. It blooms in four weeks from sowing, and continzes to flower all summer in great profusion. The blossoms are a lorely chade of blue, shading to white at the center of the throat. Pkt..3c.

\section{\$250.00 IN CASH PRIZES FOR FLOWERS}

GROWN FROM MY SEED... 


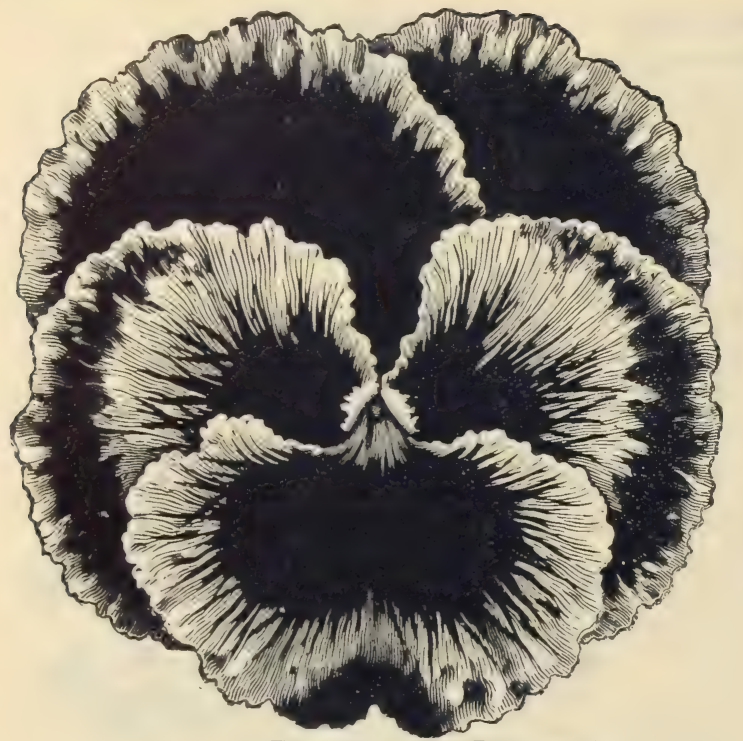

Royal Challenge Pansy Mixture.

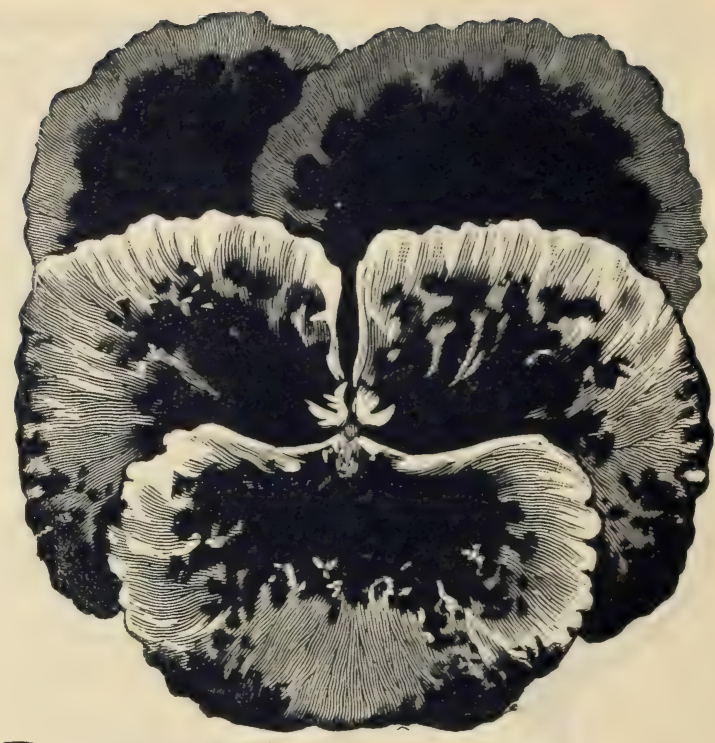

This is my special mixture, and I have taken great pains to make it the best on the market. It contains all the following named Giant Pansies and many other desirable strains and mixtures, all large-flowering. I should be pleased to publish all the good words that come to me for this mixture, but it would fill too large a space in my catalogue. Pkt., 10 cts.; 2 pkts., 15 cts.

Giant Blue Pansies. A splendid mixture of various large flowering blue Pansies, including Giant Emperor William, a beautiful ultra-marine blue, with purple violet eye; also handsome shades in light, black and violet blue. Pkt., 6 cts.

Giant Odier, Cassier and Bugnot. A superb mixture of these famous, large-flowered, spotted Pansies. The petals are large, of various colors, in the center of three, or sometimes of all five, of which are dark, velvety blotches, shading out toward the edges and ending in fine, hairy lines. Pkt, 6 cts.

Giant White. The upper petals are pure white, with large, deep violet blotches at the center on the lower petals; a beautiful thing. Pkt., $\boldsymbol{G}$ ets.

Giant Yellow Pansy. A glossy yellow, with large black eye, forming a vivid contrast to the pure golden color of the surrounding petals. Pkt., 6 cts.

Delhi, Ia., Feh., 1900 - "We were much pleased with your Pansy seed; our Prim. roses were quite a success, and we were delighted with our Giants of California Pe. tunia." Emma L. Brayton. 


\section{PANSIES.}

Lowell, Mich.. Mar.. 1900."I had some of your flower seeds and was very much pleased with them. The Pansies were the nicest ever saw.

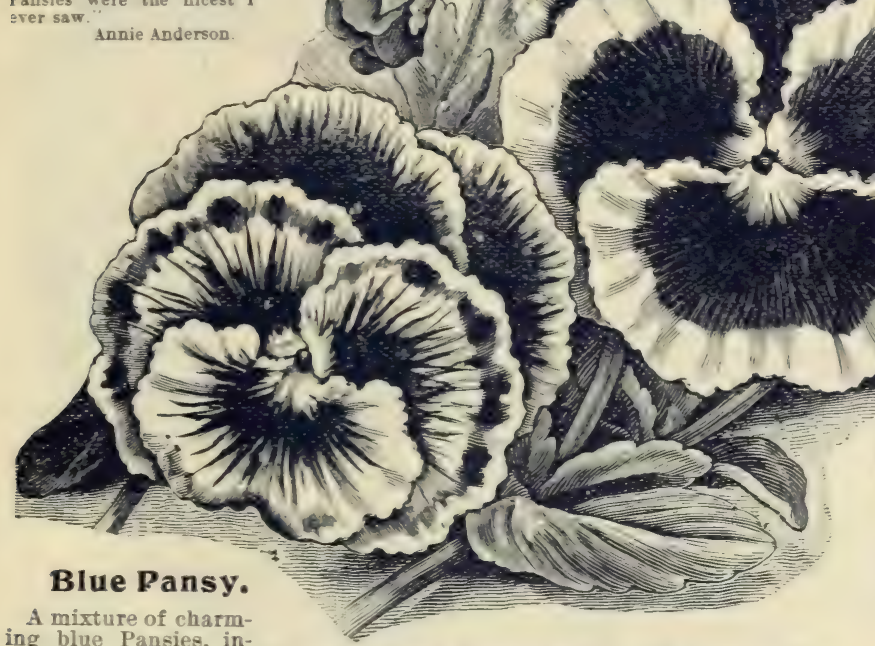
ing blue Pansies, in

cluding Emperor William, a deep ultramarine blue: Peacock, the uppor petals dewp blut. the lower claret. margined with white: Delicata, light porcelain blue with white center: other charming varieties. Pkt. $4 \mathbf{c}$.

\section{Bronze Pansies.}

A distinct class, in various shadms of bronzw. both light and dark, some with a satiny finish, others curionsly mottl-d. Mixed. Pkt., 4 cts.

\section{King of Blacks Pansy.}

A beautiful rich coal black. with a glossy, vivety finish; flowers large and of good substance, coming true from seed. Pkt., 4 cts.

\section{Rainbow Pansy.}

A quadri-colored Pansy, very beautiful. Pkt., 4 cts. eilver or gold: Fire Dragon, sellow, claret and maroon: Victoria, the nearest approach to a scarlet in pansies, together with other red shades and markings. Pkt., 4 cts.

\section{Snow Queen Pansy.}

A mixture of pure white, white with a dark center, and white with violet eye, making a wonderfully pretty show when massed by themselves. Pkt., 4 cts.

\section{Sweet Scented Pansy.}

A new class, obtained by hybridizing the Pansy with the Violet, affording the sweet perfume of the latter and the large and many-colored blooms of the former. Pkt., 5 cts.

\section{Finest Mixed Pansy.}

A mixture of the above described Pansies, together with numberless other shades and combinations, Pkt., 3 cts.. 2 pkts., 5 cts.

Ida Grore, Ia., Mar., 29, 1900.-- "I have used your seeds for three years and am better pleased with them every year. 


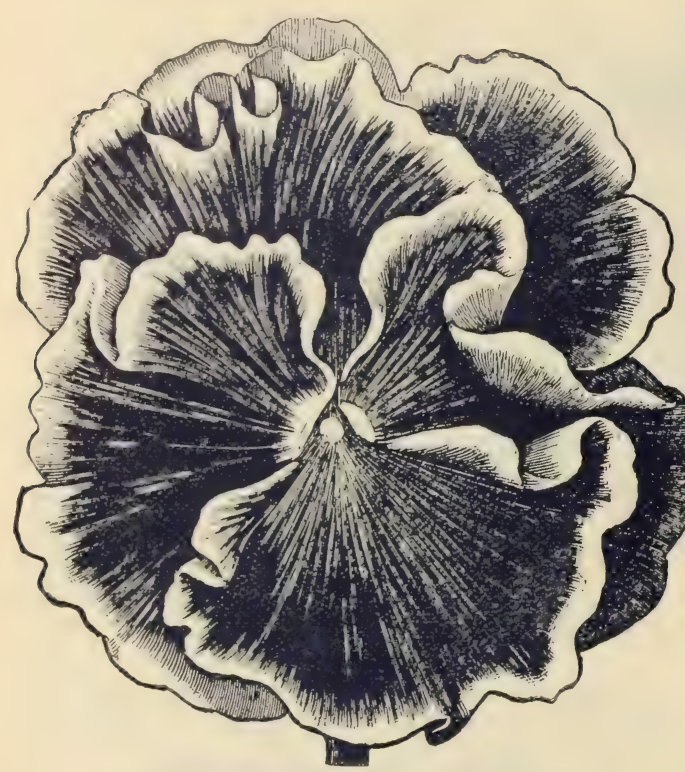

GIAN'T PANSY, "Masterpiece."

I am glad to be able to offer my customers this remarkable new Pansy. The border of each petal is conspiciously curled or fluted, giving the flower a unique double appearance. The enormous blossoms are borne well above the foliage on strong stems. They come in various colors, some tints being distinct from those found in any other pansy. Each petal is marked with a large dark blotch, and most of the flowers are margined with a white or yellow edge. Pkt., 8 cts.

Gardner, Mass., Aug., 1900.-" "This makes my third order this year. All my seedling plants are doing well. The Portulacas are beautiful. Eaeh day finds some new variety open.

\section{Physalis Franchetti}

The Chinese Lantern Plant, introduced from Japan, allied to the Winter Cherry. Noted for its ruby red fruit encased in large inflated husks, which turn to a bright orange scarlet in the fall. The fruit may be used for preserving or eaten raw. Hardy perenniai.

Pkt., 4 cts.

\section{zomomanam}

Duplicate Catalogues... \{ Should you re- \{ copy of this Cat-3 alogue please hand it to some in flowers.

\section{Lushton} Lushton, Neb., March, 1900.- This is the third year 1 have ordered my seeds from you. I have been well plsased with Mrs. Minnie Myers.

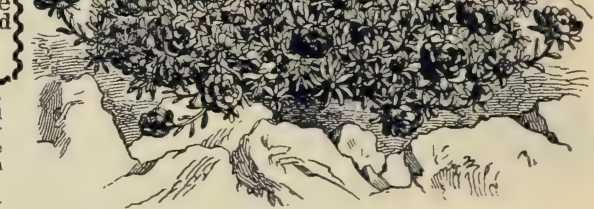

\section{Double Portulaca, or "Moss Rose."}

Low trailing annuals, with mauy brilliant colorings and variegations. The flowers are densely double, like charming little roses. A very eatisfactory plant, it is so hardy and succeeds almost anywhere. The seed here offered is of the choicest, a very large percentage coming double. Mixed. Pkt., 4 cts.

\section{Single Portulaca.}

Just as handsome as the double in brilliancy and variety of color. Pretty for a border or to mass in a bed or on some sunny slope. Mixed. Pkt., 2 ets.; $1 / 40 z ., 12$ cts.

\section{Perilla Nankinensis.}

Ornamental foliage plants, pretty for the tropical bed. The leaves are a very dark, glossy purple, and make a fine contrast to use with yellow or silvery-leaved plants. Hardy annual, growing freely in anp soil. Pkt., 3 cts. 


\section{PETUNIAS...}

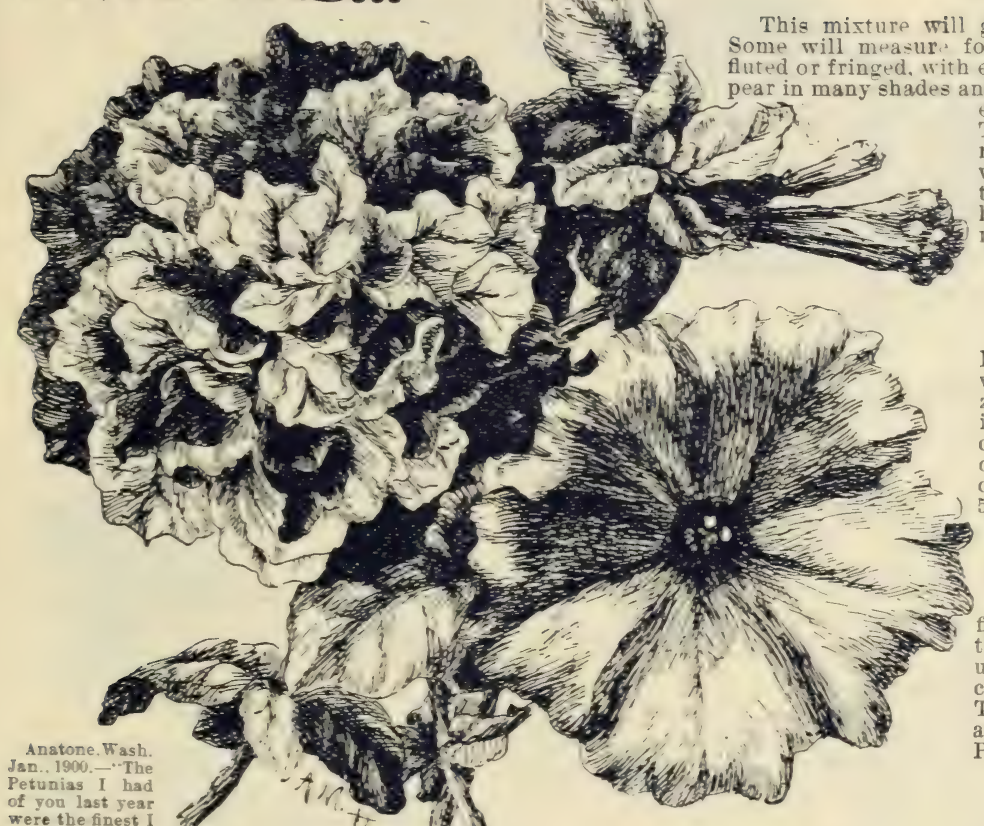

\section{Snowball Petunia.}

Sidney, Tex., Jaz, 1900.-_ "I had bean tiful Phlox and Petanias from your seed last year."

$$
\text { Mrs. Cassie Johnson. }
$$

Marshall, Mich., April, 1900.- "I would not be without your little 'Culture of Flowers.' It is worth many times the amount of my orders."
Mrs. C. B. Powers.
A Liliput Petunia growing eigh or ten inches high, bearing hundreds of beautiful white, satiny blossoms. Fine for edgings.

\section{Giants of California. \\ Single.}

give as handsome Petunias as warp prer produced. fur or five inches across. the corollas being rufted.

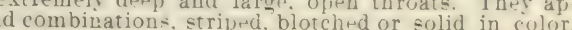
each one a "thing of beauty" and a perpetual d-light. The seed is raised by parties who have been experimenting in Petunias for sereral years and who have won a wide reputation for their beautiful productions. They grow also for the Eastern seedsmen, hence this is the same strain you would get in that market. Mixed. Pkt., 8 cts.; 2 pkts.; 15 cts.

\section{Giants of California.} Double.

What is said of the abore applies also to this class. Flowers deeply and finely fringed and of beautiful varieties. Double Petunias seed only by hand fertilization, hence the seed never has quite so much vitality as that of the common variety, and does not all come double. This seed will give a good percentage of beautiful, double-iringed flowers. Those that come single will be of choice varieties. Mired. Pkt.. 50 seeds, 10 cts.; 2 pkts., 15 cts.

Double White. Pkt., 40 seeds, 10 cts.

\section{Petunia Inimitable.}

Nothing makes a finer show in the garden than a fine strain of Petunias. Throughout the summer they give a wonderful wealth of color. Don't give up your space to faded-out blossoms, when new and choice varieties may be obtained for a few cents. This mixture will give various solid colors, stripes, and includes also the beautiful "Star Petunia." Mired. Pkt., 3 cts.; 2 pkts., 5 cts.

\section{Liliput Petunia.}

Otherwise listed as the "Dwarf Inimitable" and"Star Petunia." The plants are compact and completely covered throughout the season with richly colored, starred and mottled flowers. No nentral shades in this mixture, but virid crimsons and magentas and beautiful pink shades. For all common purposes this is really the most desirable petunia I offer.

Pkt., 4 cts.
Pkt., 4 cts.

Yew Trier, Minn.. Feb., 19(x),_" Mr Pansies last year were beautiful, as were ny Duuble Petunias. 


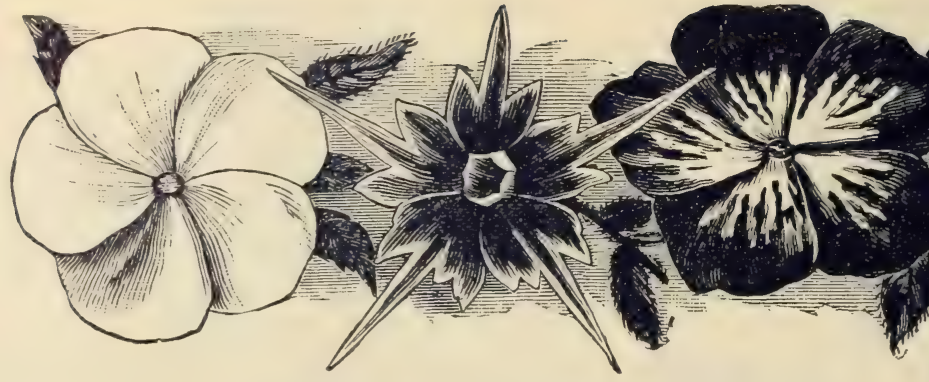

\section{PHLOX DRUMMONDI.} Phlox Grandiflora.

A bed of Phlox insures perpetual bloom and supplies an abundance of cut flowers for the house. Its hardiness, easy cultivation, rich colorings and long keeping make it an indispensable feature of the summer garden. The Grandiflora is a large-flowering variety, both the single blossoms and flower heads being very large and showy. This is my special mixture of named varieties. Pkt., 4 cts.; 2 pkts., 7 cts.

\section{Double White Phlox.}

The single Phlox I should certainly pronounce the more desirable, but include this in my list because of its exceptional value for floral designs, decorations and all cut-fiower purposes. Massed in a bed, it is atso very handsome. Pkt., 4 cts.

\section{Fringed and Star Phloxes.}

A mixture of the Fringed, or Fimbriata, and Star of Quedlinburg Phloxes, both of which are represented in the cut. The petals of both are toothed or fringed: in the former they are bordered by an irregular line of white, while in the latter each petal sends out a long point, giving the blossom a star-like appearance that adds much to its daintiness and beanty. Found in all the Phlox colors. Mixed. Pkt., 4 ets.; 2 pkts., 7 cts.

\section{Hortensia Dwarf Phlox.}

A lovely dwarf variety only about six inches high and very compact. Splendid for edgings. The single blossoms, as well as the clusters, are smaller than in the common Phlox, but they are borne in abundance and appear in many new and beautiful colors, forming a floral crown for each little plant which will last for weeks. Mixed. Pkt, 4 cts.

Phlox Drummondi, Mixed. The above varieties mixed. Pkt., 4 cts.; 2 pkts., 7 c.

Collection of Phlox. One pkt. of each of the above varieties, 12 cts.

Bradford, Pa., April, 1900._-"The flowers raised from your seed last year were a source of endless delight. My wife contributed many bouquets to the W. C. T. U. home mission work

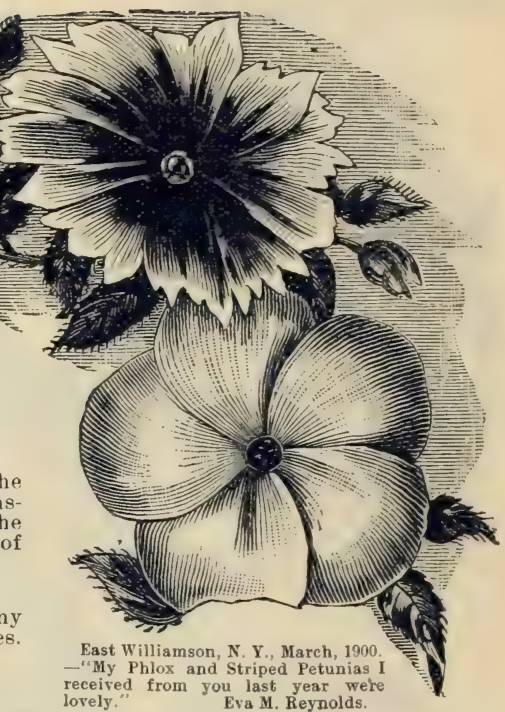

\section{Perennial Phlox.}

As I ride through the country or towns and see the homely, faded-out magenia shades of the Perennial Phlox, I wonder if people know of the many and greatly improved varieties of this Phlox, It is so hardy and easily cultivated, taking care of itself. and makes such a fine show in the garden, I wonder, also, that every one does not cultivate it. For four cents you can get some of the newest and choicest hybrid varieties. Why not try it? Finest mixed. Pkt, 4 cts.; 2 pkts., 7 c. 


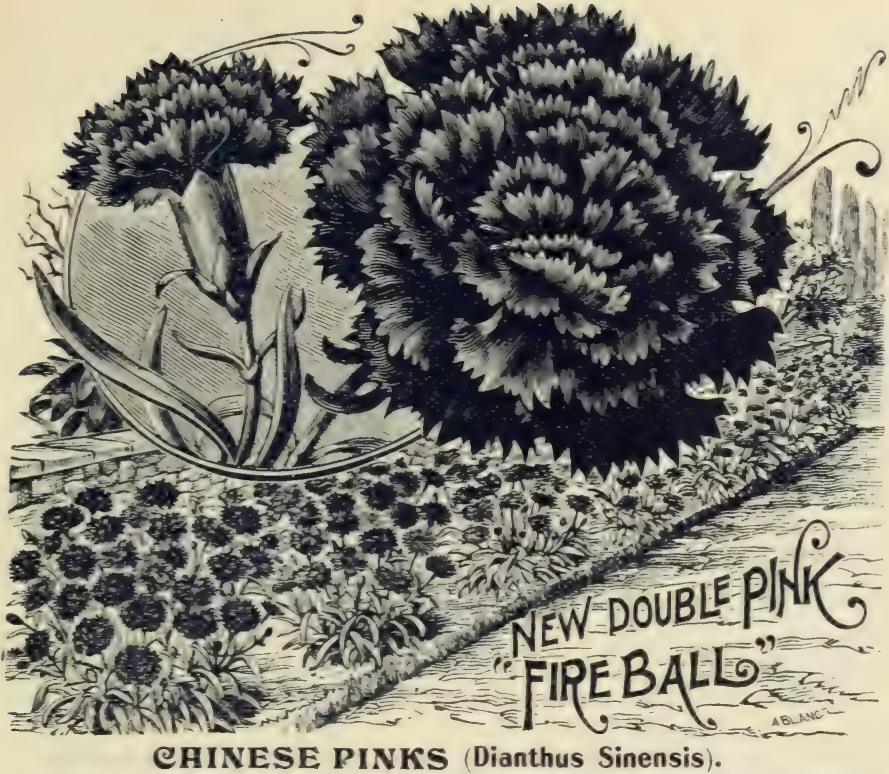

Double Fringed. A magnificent variety, with large, double, fringed and beantifully colord liowers, from the purest white to rich, velvety reds. Mixed, extra. Plit., 4 cts.

Giant Snowball. A large flowering, double white Pink of the Heddewigi type. Very free flowering. Pkt., 4 cts.

Mourning eloak. A large double flower of velvety blackish purple, margined and fringed with white. Pkt., 4 cts.

Salmon Queen. A late novelty in single pinks. A beautiful salmon pink, with finely fringed edges. Pkt., 4 cts.

Single Fringed. Blossoms laret and disc-like, some in solid colors, others mottled or zoned. A desirable strain. Mixed. Pkt., 4 cts.

Dianthus Plumarius, "Pheasant Eye" Pink.

The old-fashioned garden pink. bearing in the early spring its clove-scented flowers in great profusion. Pkt., 3 cts.

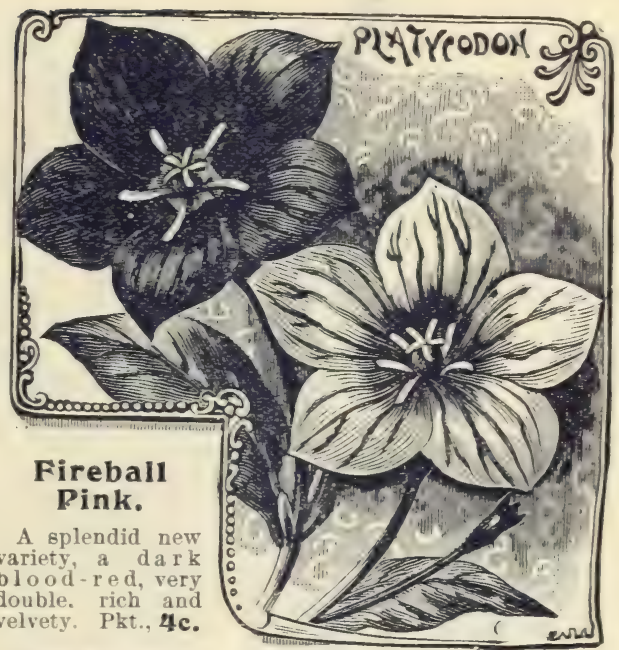

JAPANESE PINKS, "Oriental Beauties." A strain from South Japan, more beautiful, if anything than the Chinese varieties, bearing very large flowers, many of them exquisitely fringed and fluted: the colors, range from pure white, through shades of pink and red to the darkest velvety crimson and black. If cut back they will bloom throughout the summer. Pkt., 5 ets.

Pinks Mixed.

A mixture of my eight kinds of Pinks. Pkt., 4 cts.; 2 pkts., 7 cts.

\section{Platycodon.}

A hardy perennial, blooming the first year from seed. Its buds are very curious, the petals being joined at their edges, forming a perfect puff ball, whose development it is interesting to watch. The flowers are large and starlike, a rich deep blue or pure white in color. with delicate veinings or pencilings on each petal. Pkt.. 4 cts. 


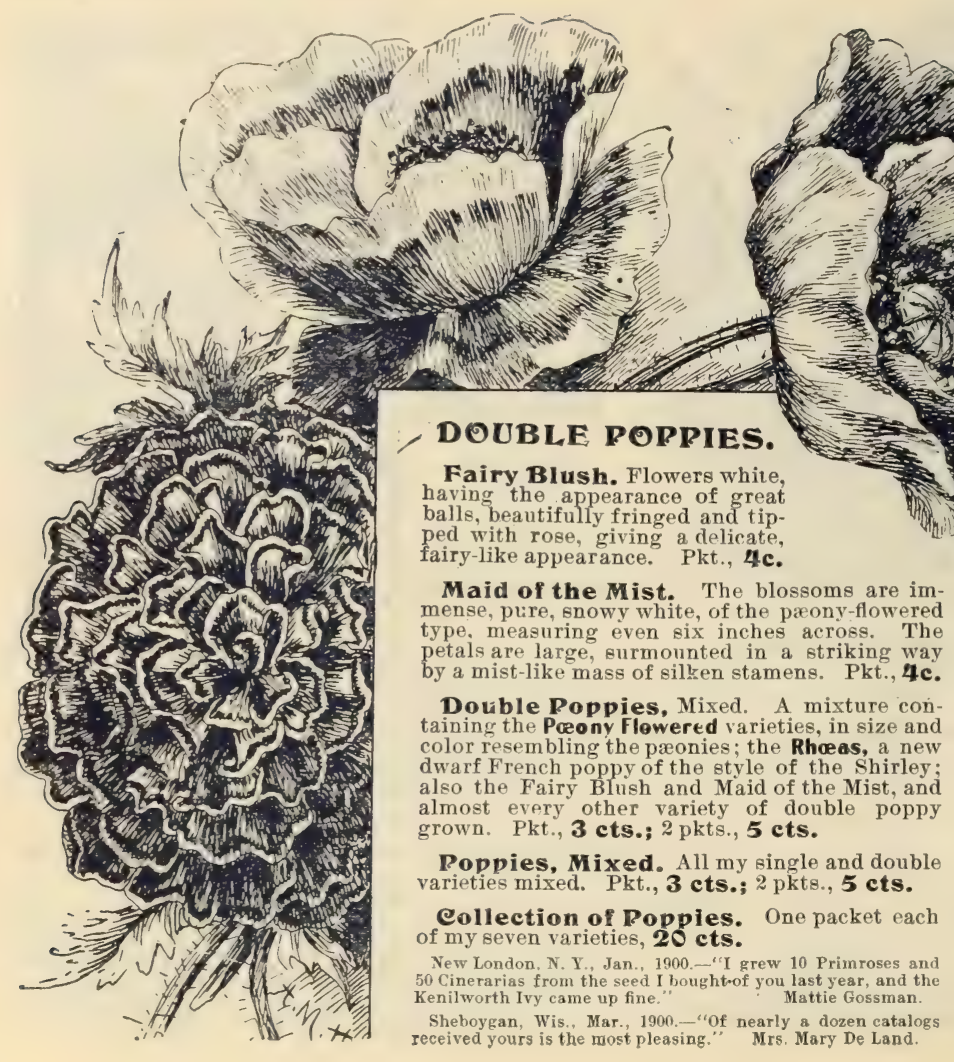




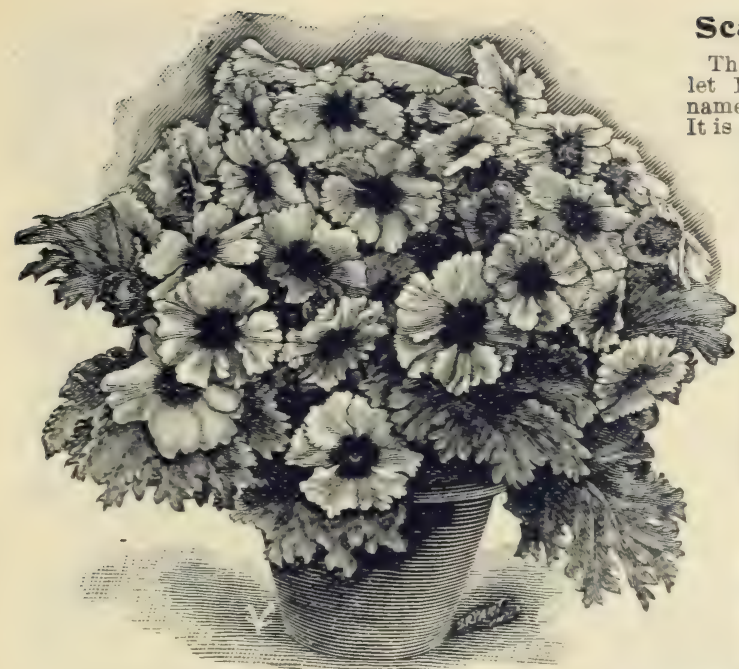

Scarlet Runner.

The bean known as Scarlet Runner is highly ornamental as well as useful. It is a rapid climber, grow- 4 ing to a height of ten iage and flower is as its more aristocratic neighbors.

Pkt.. 3 ets.

\section{PREMIUMS}

$-\mathrm{OF}-$

Plants or Seeds

Offered on ....

Orders of 50c or More.

See page 1.

\section{Primula Sinensis (Chinese Primrose).}

Primulas are easily raised from seed. My " culture of Flowers." which each customer receires, gives careful directions. br which an amateur mar succeed with them. Ther bloom vear after vear, but new plants alway: blossom more freely, and it is well to sow sped each year. Yothing blooms more continuously or gives more satisfaction for the window than the Primulas.

Primula Fimbriata. Mixed. Splendid mixture of new varieties: flowers extra large, with beautifully fringed and crinkled edges. Pkt., 40 seeds. 7 cts.

Primula Fimbriata, Red (Kermesina). Pkt.. 40 seeds, 7 cts.

Primula Fimbriata, White. Pkt.. 40 seeds. 7 cts.

Primula, Good Mixed. C'hoice and beautiful varieties. Mixed. Pkt., 50 seeds, 5 cts.

Cleveland, Mont April. 19ig) - I have been trying for three years to get Heliotrore from seed, but never succeeded until I tried yours."

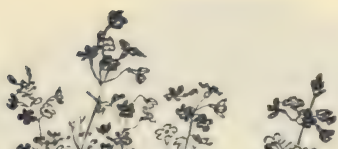

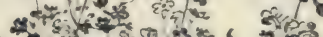

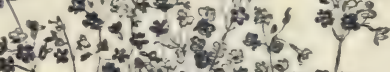

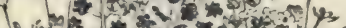

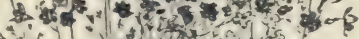

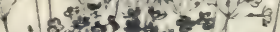

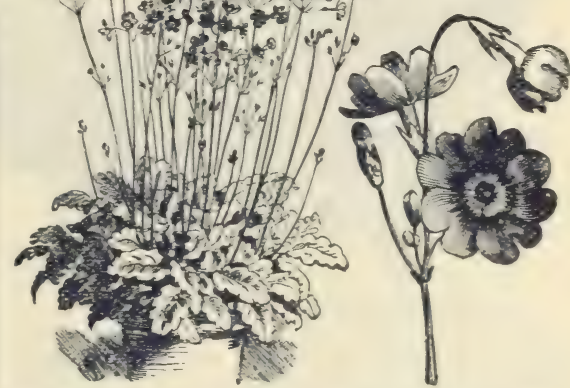

Primula Forbesi, "Baby Primrose."

One of the "cutest" little plants imaginable. It begins to flower in three months from sowing, and will continue to bloom for months. The flowers are small, hardlv half an inch across, of a pleasing rose color with a yellow eye, and are borne in clusters on long erect stems. The plant is vigorous and hardy, thriving even in unfarorable locations.

Pkt.. 50 seeds. 5 cts.

\section{Primula Obconica.}

A distinct species, almost ever-blooming, being in flower from ten to twelve months at a time. The blossoms are pure white. sometimes shading to lilac and are produced on long stems in large showy clusters of from ten to tifteen Howers in a bunch. Pkt., 50 seeds, 4 cts. 

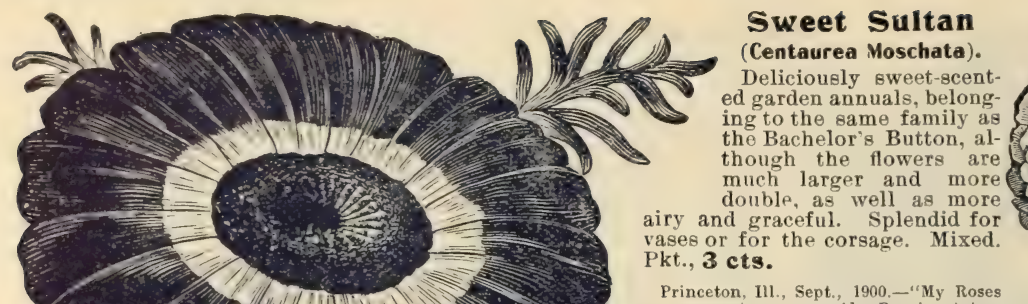
Princeton, III., Sept., 1900._-"My Roses were a great success. Also Pansies, Asters and Salpiglossis." Mrs. H. W. Hodgman. roses I got of you last year were besutiful.

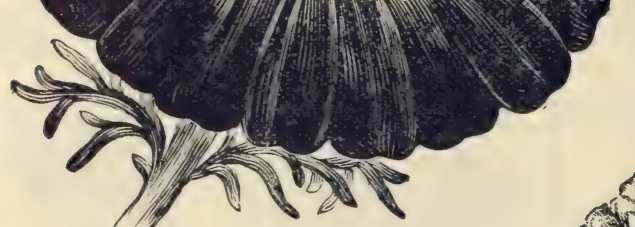

Deer Harbor, April, 1900,- "Your "Cul Deer Harbor, April, 1900.- "Your 'Cul-
ture of Flowers, is the very best guide of ture of Flowers, is the very best guide of
the kind I have seen." Mrs. W. P. Cadwell.

Pyrethrum Hybridum.

A beautiful, early-flowering, hardy perennial. The foliage is finely cut and quite ornamental; the flowers are in vivid shades of rose and pink. as large as an Aster, and remarkable for the length of time they remain perfect. Perfectly hardy and easily raised from seed. Devote some odd corner of the garden to them and grow a mass of them. They come in time for Decoration and Children's Days and are splendid for all cut flower jurposes. Very showy and pretty, and entirely hardy anywhere, even in the North. Pkt., 3 cts.

\section{Salpiglossis, "The Emperor."}

Sometimes called "Wild Beauties of Bogota." It beare very graceful, funnel-shaped flowers, growing in clusters on long stems in innumerable colors-yellow, orange, crimson, bronze, lilac, blue, purple and almost black

shades, the petals in each case being curiously marbled and penciled. Annual. of easy cultivation. The "Emperor" is a new strain, much more vigorous, with larger flowers, and a higher germinating power than the ordinary Sulphiglossis. Mixed. Pkt., 4 cts.
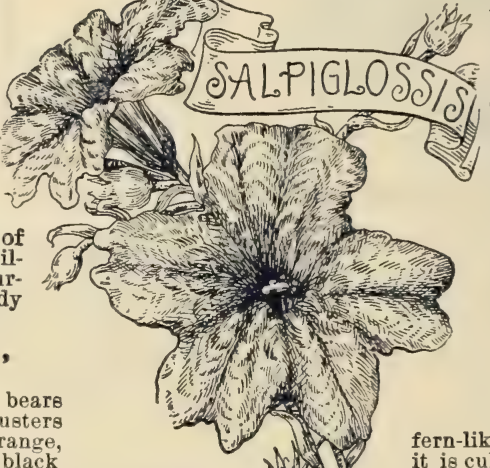

ke foliage and attractive pink blossoms, but more for its curious habit of closing its leaves at the slightest touch. Children always enjoy it. Tender annual. Pkt., 3 cts.

Troy, N. H. May, 1900, - "I was very much pleased with my Stocks. They were the finest in town. 


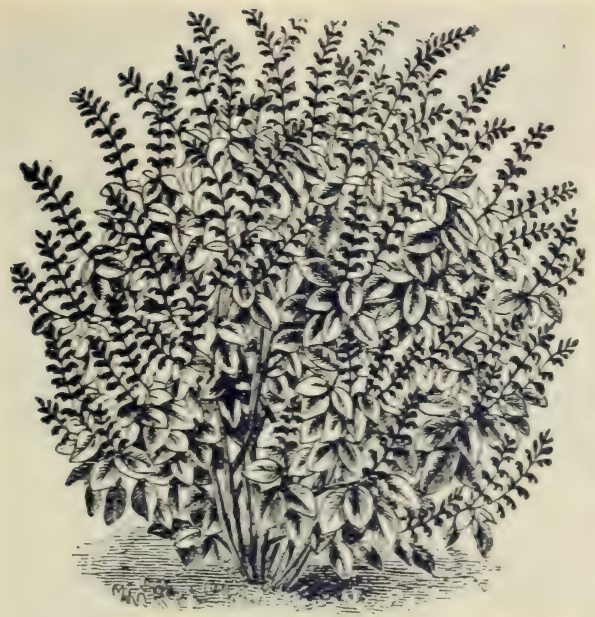

Salvia, "Bonfire."

The plants are compact, making a symmetrical, oval bush about two and one-half feet high, produc ing long spikes of most brilliant scarlet flowers. The spikes stand stiff and erect above the foliage, a single plant not infrequently bearing 200 of these fiery sprars. Gorgeous effects are produced by massing. or planting in rows with contrasting colors.

Pkt.. 5 cts.

\section{Salvia Splendens.}

The "old reliable" Salvia, suitable either for the window or garden. In its flowering season it is completely covered with long spikes of brilliant scarlet flowers. Pkt., 4 cts.

Toledo, Ia., Jan., 1900._"I have several fine plants from the package of Primrose seed I received from you, which my friends and myself greatly admire.

Mrs. Frank Doe.

Dundas. Minn.. April, 1900._ "I have tried your seeds for two jears with success.
Sweet Rocket

Hesperis Matronalis).

A hardy perennial bearing handsome clusters of white or purple sweetscented flowers. The name Hesperis means "evening"

and was given because the

blossoms are , especially

fragrant at night.

Pkt., 3 ets.
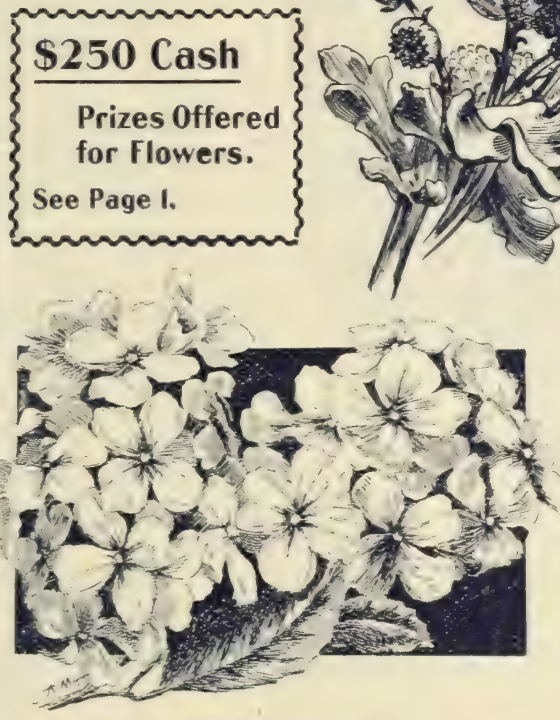

SWEET ROCKET.

Lakeviow, Mich., May, 1900.-The seeds I had from you last year were good. 1 had the loveliest flowers in town." Mrs. Dr. Joslin.

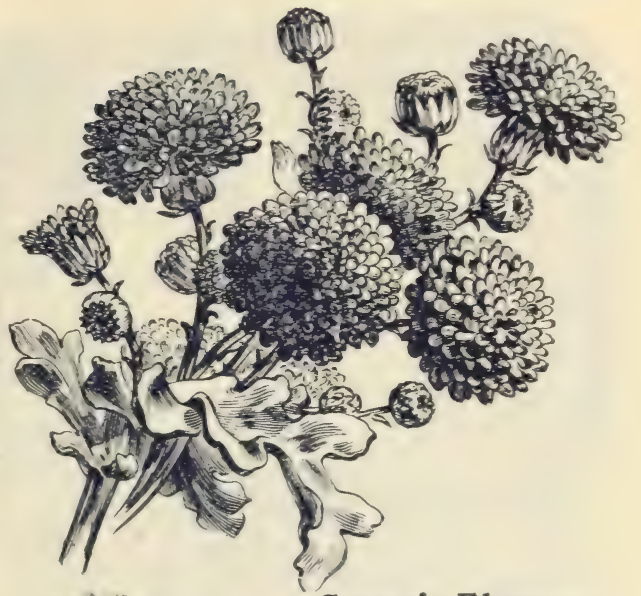

Senecio Elegans.

The Jacobaeus, a pretty hardy annual, valuable for ite long continuance of bloom. The plant is of compact habit : flowers very double, in white, purple and rose shades, and borne in such profusion as to cover the whole plant. Es pecially useful for cutting. Pkt., 3 cts.

\section{Sanvitalia}

Procumbens. A pretty low, half-trailing plant, tine for pots, baskets, rockwork or edgings. The dainty little yellow blossoms, making one think of a miniature sunflower, dot the plant the entire season, Single and double. Pkt., 3 cts. 


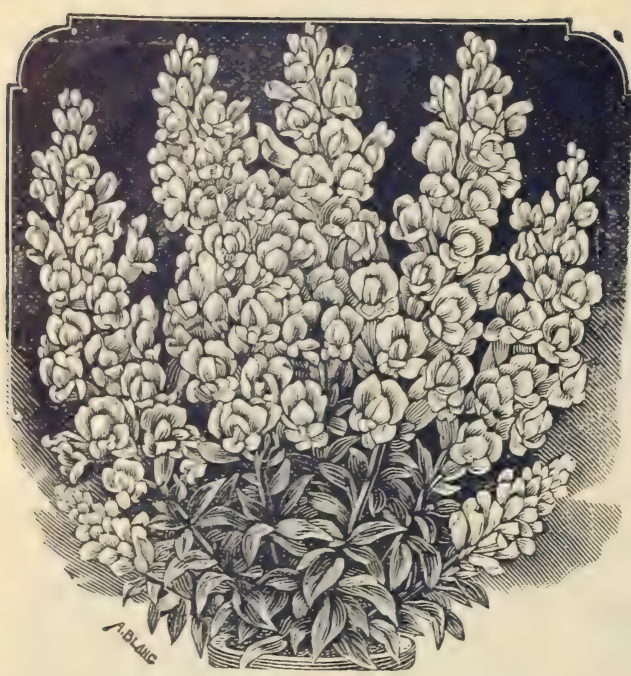

Snapdragon (Antirrhinum).

Brilliant. Crimson, with yellow and white throat. Pkt., 4 cts.

Niobe. A beautiful new variety. The tips of the flowers are a velvety crimson maroon, the throat pure white, making a striking contrast. Pkt, 4 cts.

Queen of the North. A beautiful variety, bearing large white, sweet-scented flowers. The plant is compact and bushy, and is well adapted for pot culture. (See cut.) Pkt., 4 ets.

Giant Mixed. A splendid mixture of this old-fashioned favorite, with giant flowers in many brilliant shades, including also my three named varieties. Pkt., 3 cts.; 2 pkts., 5 cts.
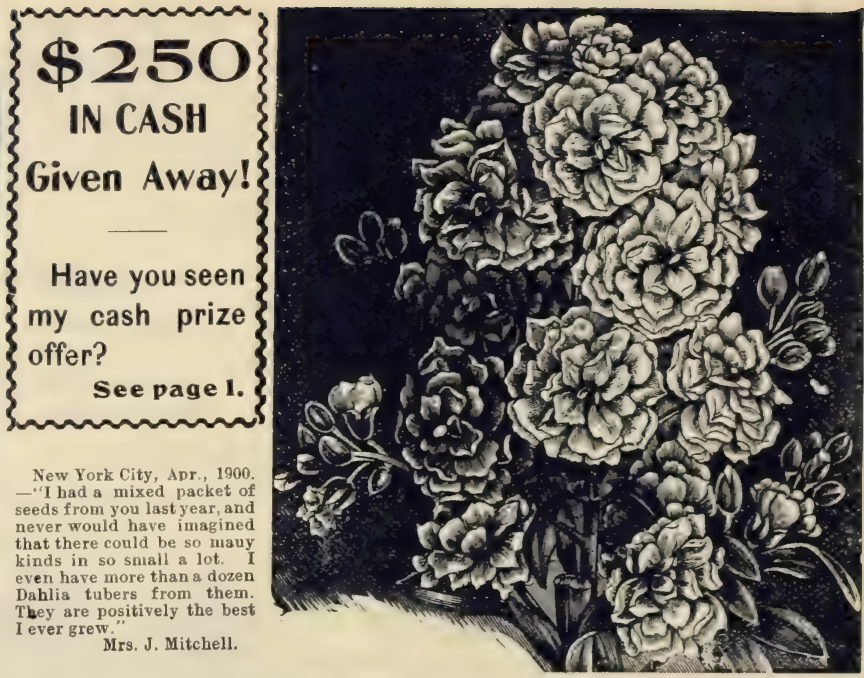

Snowflake Stocks.

A superb, large-flowered variety, bearing snowy white flowers, splendid for cutting and the best for potting. The flowers are very double and crowded together in a compact spike and bloom from early spring to late fall. Also listed as "Princess Alice," or "Cut and Come Again" Stock. Pkt., 4 cts.

\section{Giant Perfection Stocks.}

The Gillifiowers of our grandmother's time are hardly recognized in the showy Ten Weeks Stocks of today, so greatly have they been improved. The Giant Perfection is a beautiful strain, with flowere white, old pink, mauve, red, purple, blush, etc. Pkt., 4 cts.

\section{Dwarf German Stocks.}

This is an extra fine strain of large-flowering Stocks. The plants are compact and free błoomers, and furnish all the desirable shades. Annual. Mixed. Pkt., 3 cts. 

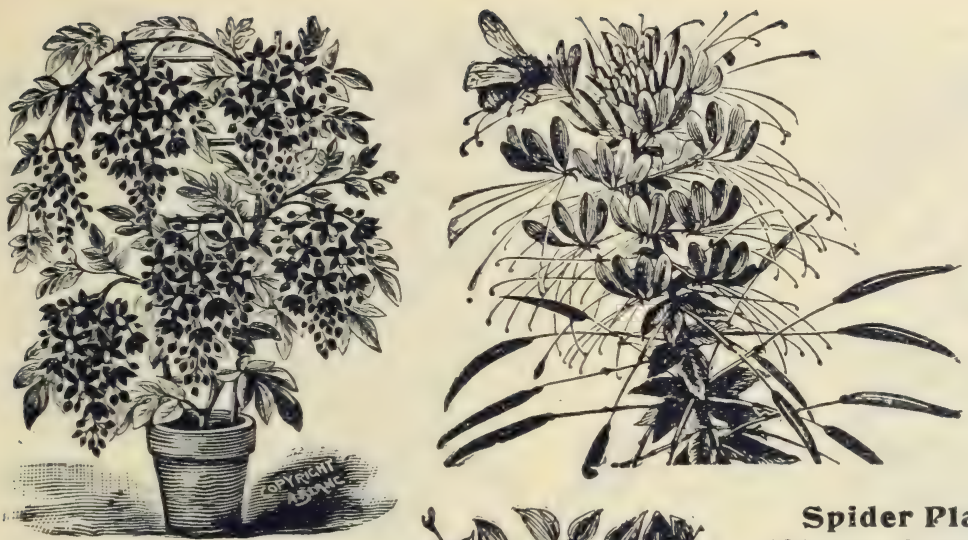

Swainsonia Alba.

A pretty greenhouse plant, generally sold only by the florist, but it comes also from seed. It may be trained as a vine, or kept in bush form by pinching back. The foliage is slender and fern like, and the blossoms, pure milk-white, like miniature sweet peas, are borne in long clusters of fifteen to twenty-five in a bunch. It is almost never without flowers. Perennial. Pkt., 10 seeds, 8 ets.

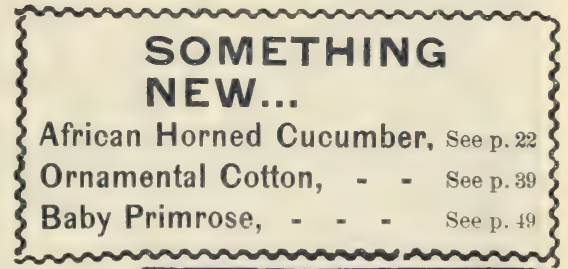

Solanum Seaforthianum.

A beautiful new climber, new in the sense that it is not yet generally known what a wonderfully pretty and desirable plant it is. The foliage is a dark green, the ends of the branches arching gracefully out and carrying a large cluster of lovely light blue, wisteria-like flowers. They continue to bloom until frost, the early maturing blossoms being followed by showy scarlet seed berries. It is equally valuable for out door trellises, or growing in pots for the window or conservatory; or it may be used without a support, as the branches are woody and grow to a height of but five or six feet. Pkt., 7 cts.

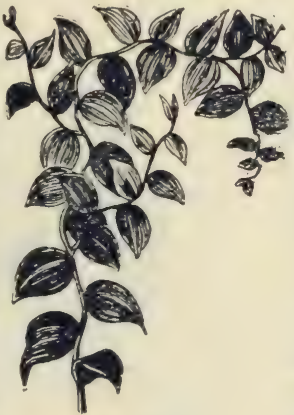

Smilax.

\section{Spider Plant}

(Cleome Pungens).

A hardy, vigorous plant whose foliage has a pungent odor. It grows four or five feet high and flowers profusely until frost. The blossoms are a whitish rose and grow in large clusters, each one throwing out long slender stamens like a spider's legs, with peculiar and striking effect. Annual. Pkt., 3 cts.; 2 pkts., 5 cts.

Salt River, Ky.. March, 1900.-" "The vegetable seeds I purchased of you were splendid, they came up better than any I have bought elsewhere in many years.

Chore

Shorey, April. 1300.- "The seed that my daughter sent for are ur anil duing finely.

No climbing plant surpasses the Smilax, not only for the graceful beauty of the vine, but for its value in decoration. The seed should be sown in pots or boxes, as it requires a month or more to germinate, but it is easy to cultivate. Although a perennial, it is better to start new plants each year, and not try to keep them after the leaves turn yellow. Pkt.. 4 cts.

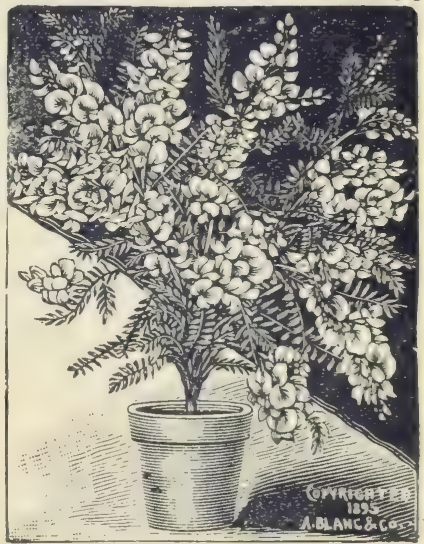

SWAINSONIA ALBA. 


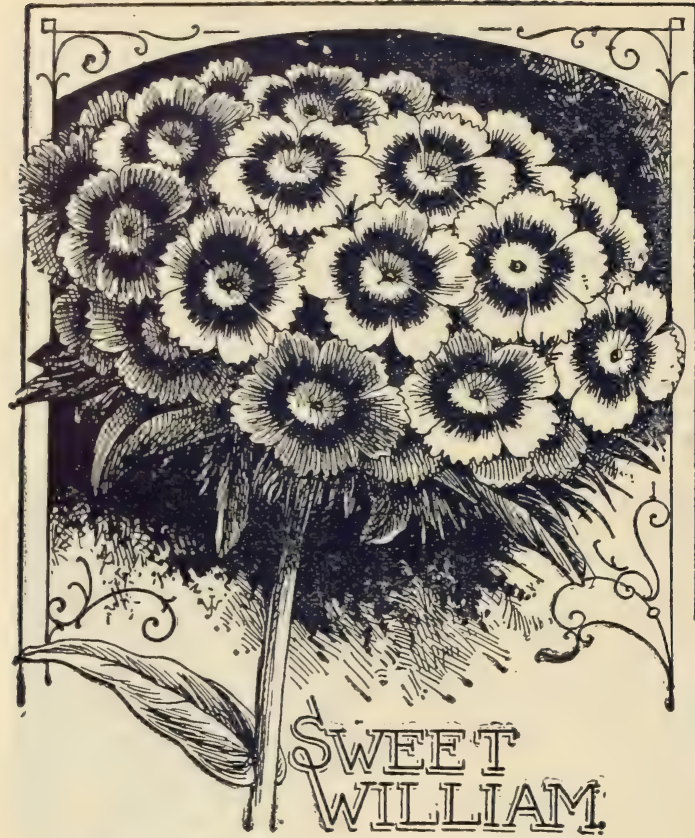

Sweet William, "New Perfection."

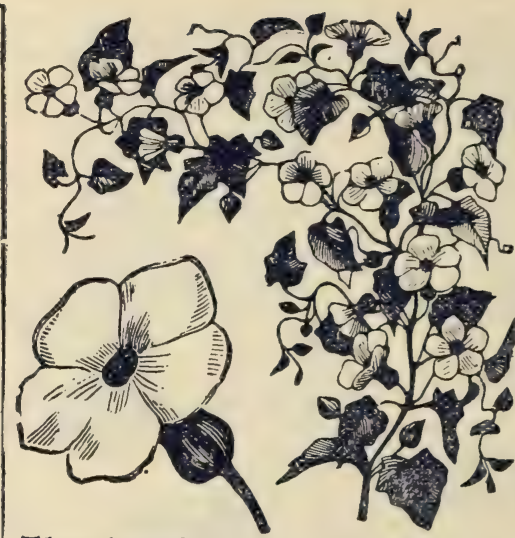

\section{Torenia}

Fournieri.

Lovely little annuals de sirable for vases, pot culture,or for the open ground in beds or massee. Often used as a border plant. The blossoms are peculia bell-shaped flowers, of a velvety, porcelain blue, with three large spots of a still darker blue, and golden throat. They will bloom continuously during the summer and also in the window in the win ter. In the garden they sow by May Pkt., 3 cts.

hanover June, 1900 - "The seeds I got of yoll are oll browin finely. The Baby Roses are bud ded to blossom."

\section{Thunbergia} Alata.

A dainty little climber, pretty for garden rases, rustic work, trellises or for trailing on the ground. The flowers are very pretty, about the size of $a$ silver quarter, and appear in white, yellow, orange and buff, some having white centers, othA handsome strain of this old favorite. The blossoms are ex- white centers, oth-
ra large, with white margins and fringed edges, and very showy bloom all summer. and attractive. Double and single, mixed. Pkt, 4 cts.

Sweet william tery easy of cultivarieties in all the colorings and markings of this hardy peren- cannot fail to give nial. If cut back after fiowering they will bloom again in the satisfaction. Mixed. fall. Choice mixed. Pkt., 2 cts.

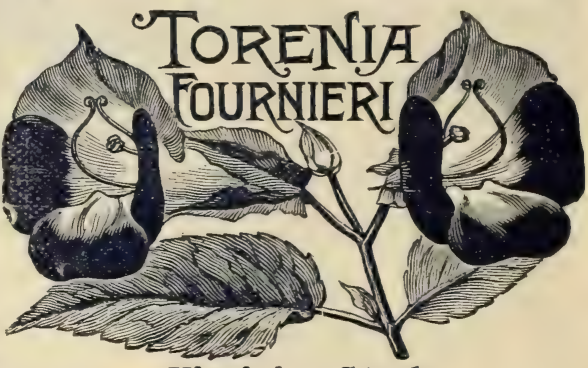

Virginian Stock.

Desirable little plants, bearing small flowers of delicate mixed colors, ranging from white through shades of lilac, lavender and magenta. Wonderfully pretty in a mass, or for edgings. Found in all old English gardens, Annual, Pkt., 2 ets. 


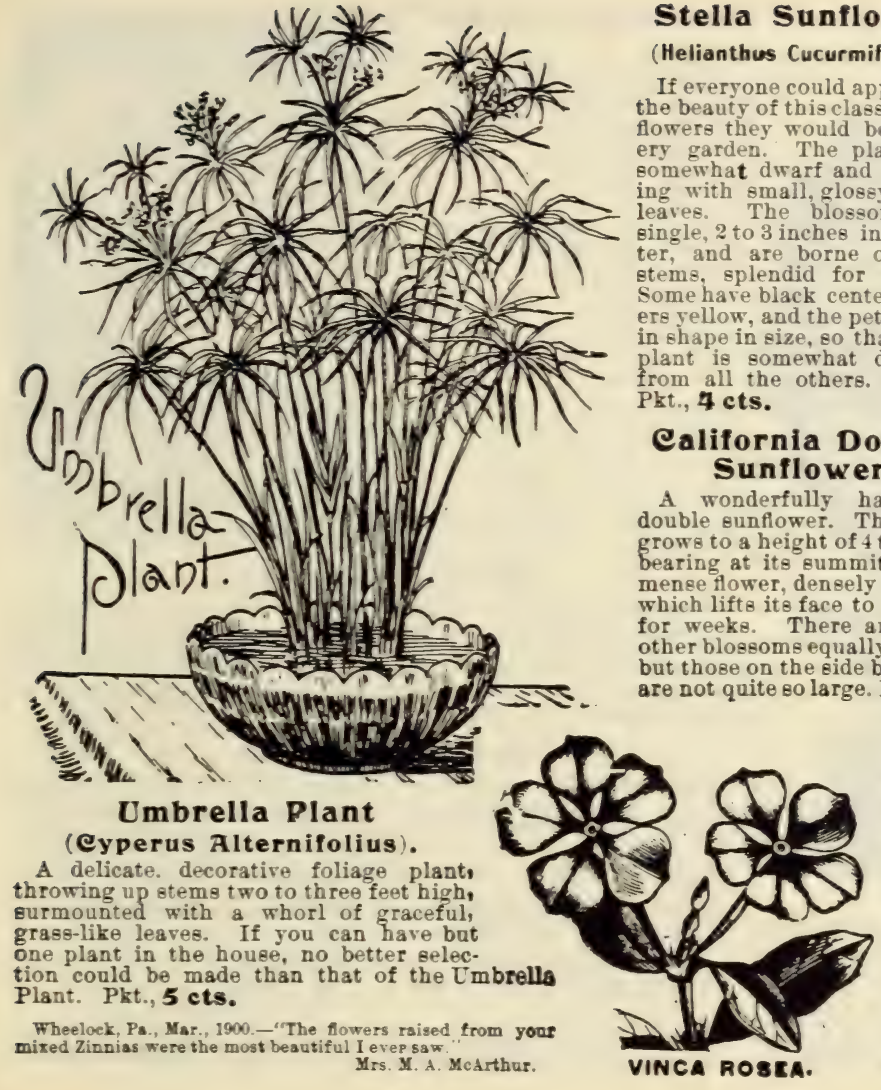

Stella Sunflower

Helianthus Cucurmifolius.)

If everyone could appreciate

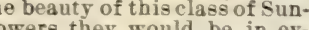
plants are blossoms are ter, and are borne on long tems, splendid for cutting. some have black centers, othpetale rary that every differen

California Double Sunflower. 4 to 5 feet. ummit an immense flower, densely double, which lifts its face to the sun weeks. There are mar. showy. quite eolarge. Pkt.4c.

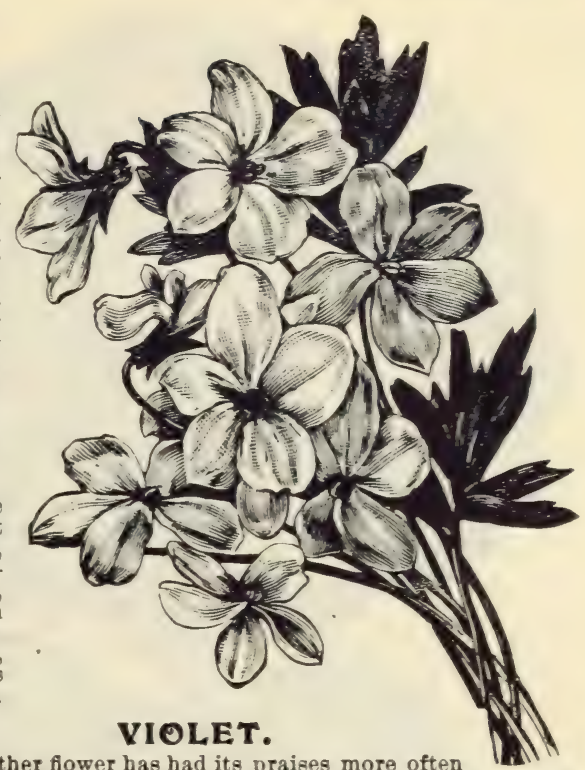

No other flower has had its praises more often sung by the lover of nature, and it has ever stood an emblem of innocence. It is easily raised from seed, though rather slow to germinate, but when once established it is the first flower to greet one in the spring. Perennial.

The Czar. A lovely, large-flowered blue. Pretty for pots. Pkt., 5 cts.

White Queen. Very fragrant. Pkt., 3 cts.

Violets, mixed. White and blue, mixed. Pkt., 4 c.

Kansas City, Mo., April, 1900.- "My Moonflowers last year were a great success.

Mirs. B. B. Seelye.

Arctic. Ind.. Mar., 1900... - I receired the seeds and am highly plessed with the quantity in the packages and prices." Jos. R. Wiley 


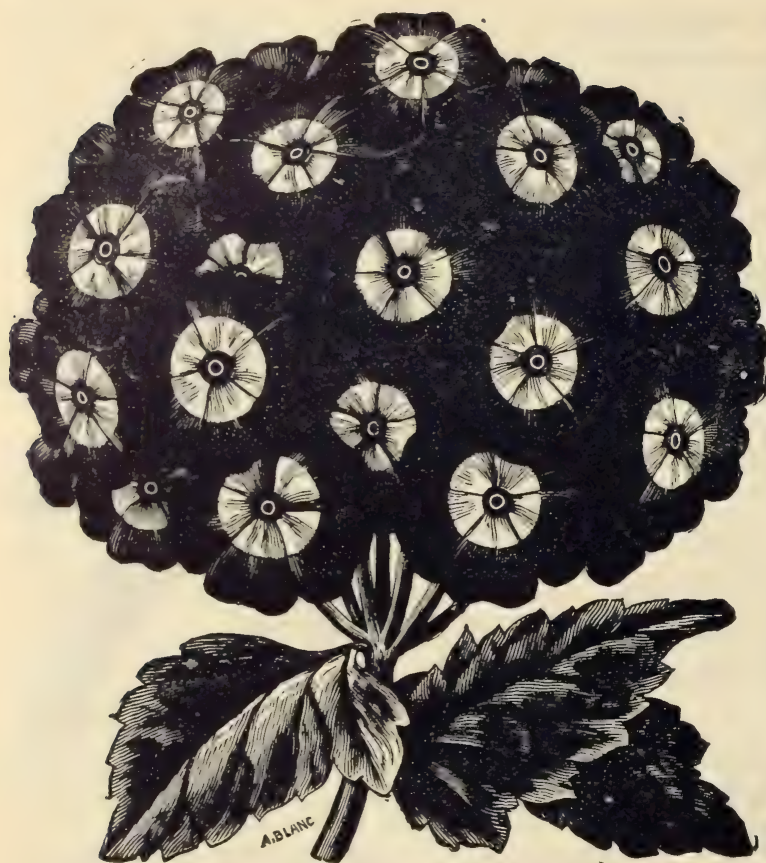

Fordhook Mammoth Verbena.

This is a grand new strain of Verbena, producing exceedingly large trusses of flowers, whose individual florets are often as large as a silver quarter, and embracing all the new and desirable colorings and markings. In some the petals are in solid colors, in others zoned, or ringed, and in still others striped or variegated. No more desirable mixture can be offered; warranted to be the same as the highest priced mixtures of other seedemen. Mixed. Pkt., 4 cts.; 2 pkts., 7 cts.

\section{German Wallflower}

This has been neglected in our country of late, though no English or German flower garden is complete without it. Its flowers are borne in large, full spikes and are deliciously fragrant. Where the winters are not severe it will live over, blossoming profusely in the early spring. Farther north, plants from spring-sown seed may be potted in August for winter flowering. A mixture of double branching and earliest lowering Parisian strains. Pkt., 4 cts.

Branchport, N. Y., April, 1900."The Cinerarias that came from your seed are lovely.

Troy, Kan., April, 1900,- "I am very much plessed with your seeds from year to year." Anna May Bohr.

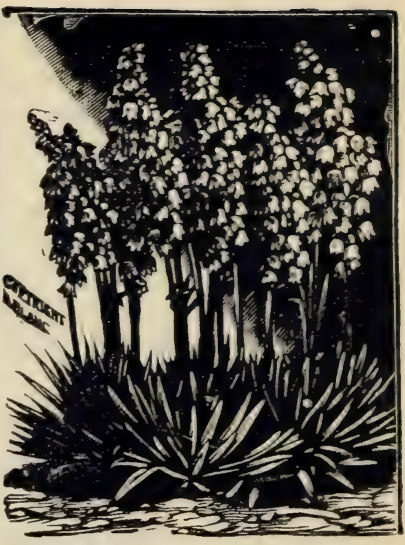

Yucca Filamentosa.

A stately, tropical-looking plant, very handsome for the lawn or garden. It is a hardy evergreen, the stem rising three or four feet high from the tuft of the narrow, bayonet-like leaves, bearing a profusion of creamy-white, bell shaped flowers. It will thrive almost anywhere, even in sandy or shady places, and is hardy even in the extreme north. Pkt., 5 ets.

\section{Verbena Hybrida.}

Giant Pink. A handsome rich pink. Pkt., 5 ct\$.

Giant Scarlet Defiance. An intensely bright scsrlet. Pkt., 5 cts.

Giant Striped. Showy mixed colors. Pkt., 5 ets.

Giant Hybrid White. A fine strain, large-flowering and pure white. Pkt., 5 cts.

Verbena Mixed. All my five kinds of Verbenas mixed. Pkt., 4 cts.; 2 pkts., 7 cts.

Liberty, Neb., April, 1900.- "Your seeds are sll right. My Cosmos was a "thing of besuty, and every seed germinated. Mrs, Emma Piper. 


\section{“HIT OR MISS" FLOWER GARDEN. -}

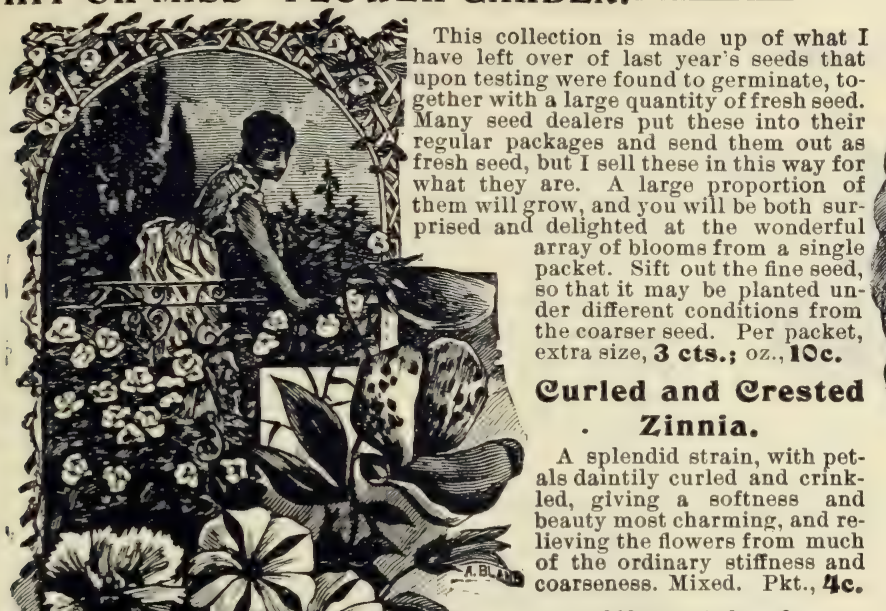

\section{Liliput Zinnia.}

A new, extra dwarf variety. The blossoms are small and

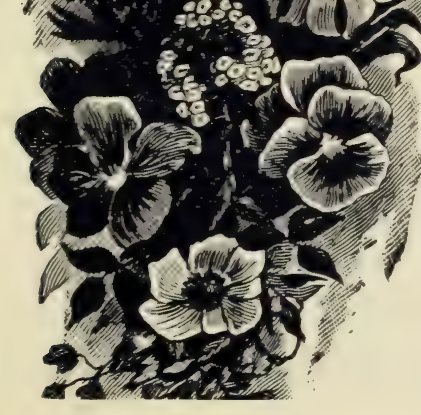
very double, thickly covering the plants
with their vivid scarlet or white, lasting till the latest frosts. Those who have barred the Zinnia because of its coarseness will be delighted with these liliputian varieties. They are as showy as a Geranium and make a splendid substitute for it in the window box or ornamental bed, at a trifling cost.

Liliput Zinnia, Scarlet Gem. A true scarlet color. Pkt., 4 cts.

Liliput Zinnia, White Gem. A lovely white Zinnia. Pkt., 4 ets. Plainfield, Ind., Dec., 1900.- ', My Pansies that I got of you were superb." Mattie Snipes.

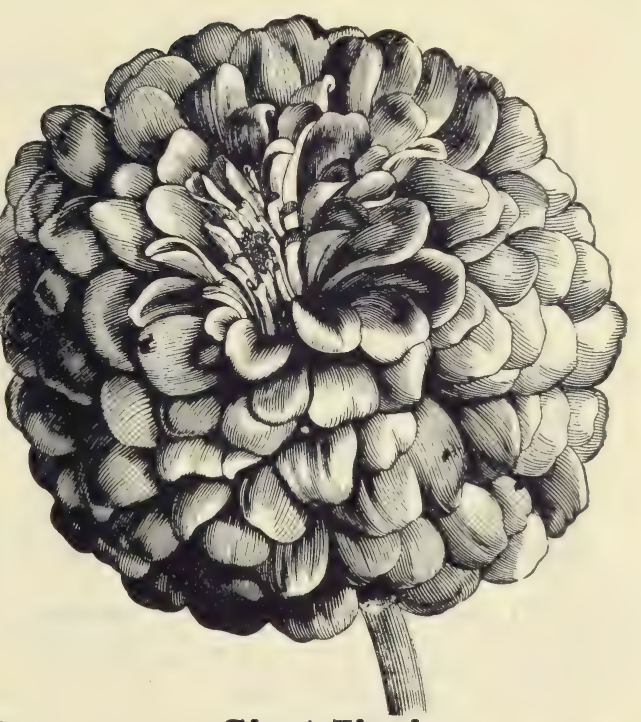

Giant Zinnia.

For grouping in a bed, nothing will furnish a more gorgeous mass of color nor give a longer blooming season than the Zinnia. This is a splendid double, large-flowering strain. Mixed. Pkt., 4 cts.

\section{Dwarf Zinnias.}

Dwart Zebra Zinnia. Yellows, scarlets and whes, all curiously marked and spotted. Pkt., $3 \mathrm{c}$.

Tom Thumb Zinnia, Mixed. Large-flowering, dwarf varieties in all the Zinnia colors. Mixed. Pkt., 3 cts.

Zinnias, Mixed.

A mixture of my six named varieties which will give an opportunity to secure them all for a small sum. Pkt., 4 ets.; 2 pkts., 7 ets. 


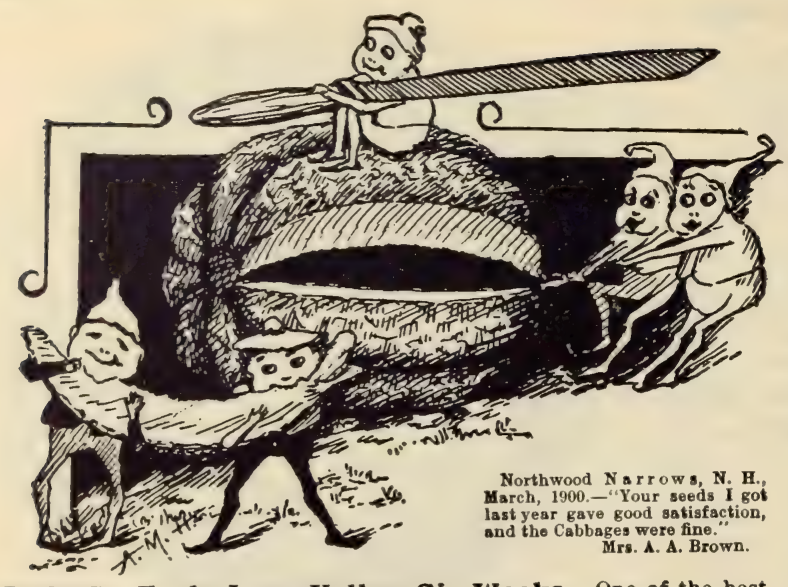

BERNS: Early Long Yellow Six Weeks. One of the best early green podded varieties; early, tender, stringless.

BEANS: Improved Golden Wax. Best early flat golden pod.

BEANS: Improved Golden Wax. Best early flat golden pod. lierthan any other green pole bean. It is stringless and can be used either green or shelled.

BEANS: Burpee's Bush Lima. No garden is complete without the Bush Lima. It is both prolific and early.

BEET: Market Garden. The ideal beet for the market gardener or home use. Skin and flesh a deep blood red. Suitable for early use or winter keeping.

CABBAGE: All Head Early. The characteristics of this splendid new Cabbage can be summarized in a few words: Earliness, large size, uniformity, excellent quality, and splendid keeper. It is an allthe-year-round Cabbage.

CABBAGE: Holland; Dutch Winter, or Danish Ball Head. Best winter keeper on account of its hard heading quality. Weight of head one-quarter more than that of any other variety of similar size.

CARROT: Oxheart, or Guerande. Flesh bright orange, fine grained and sweet. A very fine quality for table use and equally good for stock. On account of its shape it is more essily pulled than any other variety.
SELECTED

\section{VEGETABLE LIST.}

I do not make a specialty of Vegetable seeds but include in my list, for the convenience of my patrons, a few of the staple and reliable sorts. The seeds are fresh and of high germinating power, and will be found fully as desirable as the higher priced novelties offered by other seedsmen. I sell them for the small sum of

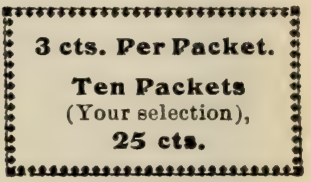

CAULIFLOWER: Early Snowball. Exceedingly early and hardy and one of the surest to make a solid, compact head; best for late summer and fall crop.

CELERY: White Plume. Handsome, crisp, self-blanching sort, of very easy cultivation. The earliest variety known. SWEET CORN: Early Cory. The earliest variety grown; quality excellent.

SWEET CORN: Stowell's Evergreen. The standard main crop variety, and if planted at the same time with the earlier kinds will keep the table supplied until October. Very tender and swoet.

POP CORN: White Rice. The standard variety.

CUCUMBER: Boston Dickling, or Green Prolific. Very popular for pickles. Fruit smooth, bright green; \& great producer.

CUCUMBER: Improved White Spine. Flesh tender and of excellent flavor. One of the best sorts for table use.

BGG PLANT: New York Improved. Large, round, purple, solid and weighty.

LETTUCE: Grand Rapids. Large and tender. One of the best for family use.

LETTUCE; Hanson Head. One of the finest hesd lettuces, very slow to seed. Inner leaves usually curved and twisted. Especially fine for salad decoration.

MUSK MELON, Early Nutmeg. Early and very prolific. Rich and sweet in flavor. One of the most desirable table sorts. 
WATERMELON: Dark Ieing. An early and favorite var. iety. Flesh a deep scarlet, juicy and luscious.

WATERMELON: Ice Cream, or Mountain Sweet. old reliable sort.

ONION: Red Wethersfield. The best keeper and one of the most popular for general cultivation.

ONION: Silver Skin (Large White Portugal). Produces early onions of mild flavor, largely used for growing sets and pickles.

ONION: Yellow Globe Danvers. One of the best for family use. Mild in flavor and an excellent keeper.

DARSLEY: Champion Moss Curled. For garnishing no varicty is more attractive. In growth it resembles a tuft of finely curled moss. Is very hardy and slow in runuing to seed.

PRRSNIP: Hollow Crown. The growing demand for this delicious vegetable makes this improved strain particularly desirable.

PBAS: American Wonder. Very early, quslity excellent; needs no brush; one of the best for private gardens.

PEAS: Stratagem. A blue, wrinkled marrow, English dwarf pea of rare excellence; medium early, $1 \frac{1}{2}$ to 2 feet. Very proliflc.

PBPPER: Large Bell, or Bull Nose. Early, large, with thick mild flesh, excellent for salads ahd pickles; color bright red when ripe.

PEPPER: Red Cayenne. Bright red. Pods small, cone. shaped, scarlet when ripe. Pungent.

PUMPKIN: Sweet or Sugar. Makes the most delicious pumpkin pies.

RADISH : French Breakfast. Scarlet, olive-shaped, whitetipped. Very crisp and tender, and of beautiful color.

RADISH : Turnip. Very early, beautiful scarlet: white-tipped.

SQUASH: Early Summer Crookneck. Very esrly and productive.

SQUASH : Hubbard. The standard winter squash. No better qariety grown.

SQUASH: Mammoth White Bush Scallop. Fruit is a beautiful clear waxy white; the best of the scalloped squashes.

SALSIFY: Or Vegetable Oyster. Sandwich IsIand. A greatly improved variety. Superior both in point of quality and flavor.

SPINACH: Long Standing. Best for family use.

төмАтО: Acme. A popular sort; early ripener, of medium size, oval and smooth. Flesh deep scarlet and solid.

TOMATO: Dwarf Champion. An early variety; flesh solid and smooth, of fine color; leads all other varieties in productiveness.

TURNIP: White Egg. Oval, smooth, solid and sweet. One of the best for table use.

\section{LAWN GRASS SEED.}

MY LAWN GRASS MIXTURE, and I make but one, is the very best that can be made. If directions are followed it will give you a soft close sod of uniform texture and rich emerald green.

DIRECTIONS. - To eecure the best lawn, the soil should be well drained and deeply plowed, and fertilized with well-rotted msnure or some good commercial fertilizer. Harrow, or rake it as fine as possible and roll before the seed is sown. Sow the seed as early in the spring as possible, raking it in lightly to partially cover it.

This mixture consists of the best grades of white clover and Kentucky Blue Grass, the latter being sun dried and hand rubbed.

Quantity Required.-For 1 acre, 4 bu., for 300 sq. ft., 1 qt.

By Mail, postpaid: One quart, 25 ets.; two quarts, 45 ets.

By Express, at buyer's expense: One quart, 15 cts.; one peck, 90 ets.

\section{SPECIAL OFFER.}

Three interesting new things for $10 \mathrm{cts}$.

African Horned Cucumber.

Bird of Paradise,

See page 22

Ornamental Cotton,

These three packets for 10 cents. See page 39

\section{PALMS And Other House Plants, 5 cts.}

Having had so many requests reguarding the care and selection of palms and other house plants, I have prepared a handsome little folder, printed on heavy enameled paper for convenient use and preservatiod, containing practical hints and suggestions along these lines. This is not an exhaustive, technical treatise, but includes in a nutshell information necessary to successful window gardening.

Add 5 cents to your order and receive this instructive folder.

This will be given as an extra premium, if desired, in addition to other premiums offered, on an order of $\$ 1.00$ or more.

For SWEET PEAS and ASTERS See Page 3 to 10. 


\section{1.}

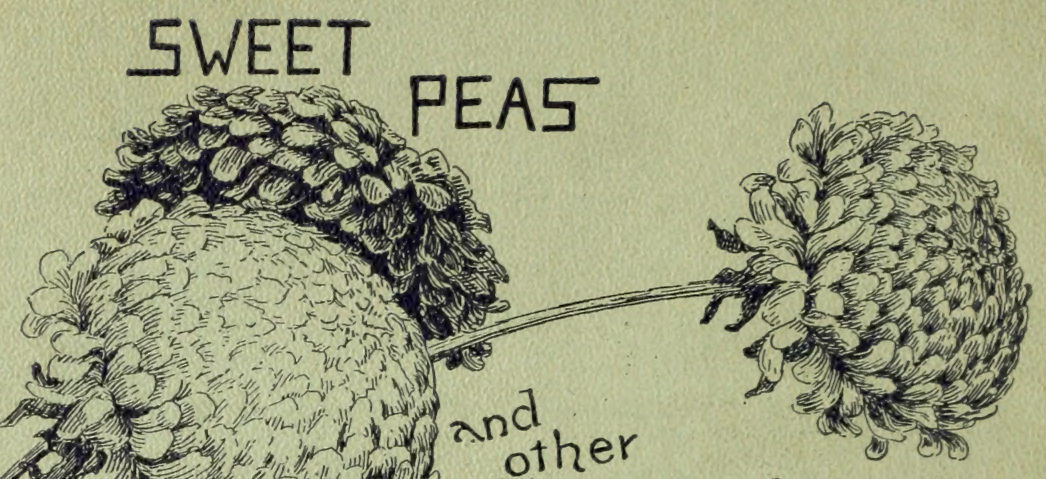

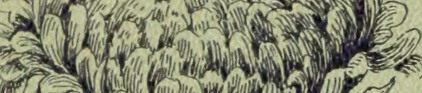
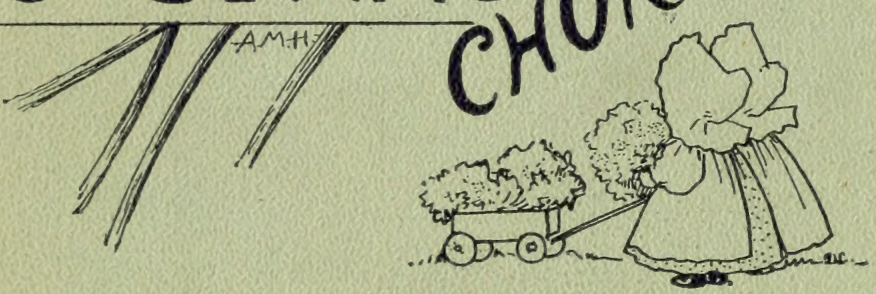

Miss EmmaV. White, 818 Nicollet Ave., Minneapolis, Minn. 

